\title{
EFFECTIVE REMEDIES FOR EMPLOYMENT RIGHTS: PRELIMINARY GUIDELINES AND PROPOSALS
}

\section{CLYde SUMMERS $\uparrow$}

Labor lawyers and scholars have become increasingly aware during the last dozen years of a broad, long-term trend toward greater legal protection of the individual employee in the employment relation. This awareness was triggered in part by the dramatic change in judicial attitudes toward employment at will. Led by courts in California, ${ }^{1}$ Connecticut, ${ }^{2}$ Michigan, ${ }^{3}$ and New Hampshire, ${ }^{4}$ the courts in a majority of states $^{5}$ have repudiated the misconceived dogma that an employee hired for an indefinite term can be discharged "for good cause, for no cause or even for cause morally wrong." Thoughtless repetition and brutal application of this wooden rule has been replaced by the use of generally accepted

† Jefferson B. Fordham Professor of Law Emeritus, University of Pennsylvania. The author is especially indebted to Patricia Hoeg, Christopher Levesque and Wendy Schwartz for their excellent seminar papers which developed much of the information on which this article was built, and also for the helpful research work of Stephen Smith and Jose Oxholm-Uribe.

1 See Tameny v. Atlantic Richfield Co., 610 P.2d 1330, 1337 (Cal. 1980) (holding that a tort claim is available for wrongful discharge); Cleary v. American Airlines, Inc., 168 Cal. Rptr. 722, 726 (Cal. Ct. App. 1980) (noting that "in many different contexts, there are practical, legally recognized limitations on that right to discharge at-will employees"); Petermann v. International Bhd. of Teamsters, Local 396, 344 P.2d 25, 27 (Cal. Dist. Ct. App. 1959) (holding that considerations of public policy may create an employee claim of wrongful discharge).

${ }^{2}$ See Sheets v. Teddy's Frosted Foods, Inc., 427 A.2d 385, 389 (Conn. 1980) (holding that a cause of action in tort arises from a wrongful discharge in violation of public policy).

${ }^{3}$ See Toussaint v. Blue Cross \& Blue Shield, 292 N.W.2d 880, 890 (Mich. 1980) (holding that an employee may maintain an action for wrongful discharge where the employer violates its own policy to terminate only for good or just cause).

${ }^{4}$ See Monge v. Beebe Rubber Co., 316 A.2d 549, 551 (N.H. 1974) (holding that bad faith termination by the employer constitutes breach of the employment contract).

${ }^{5}$ Forty-two states and the District of Columbia have recognized a cause of action in employment at will cases based on violations of public policy. Thirty-three states and the District of Columbia have made available a wrongful discharge action based upon contract theory where an employer has violated its policies, handbooks, or other representations. See [9A Individual Employment Rights Manual] Lab. Rel. Rep. (BNA) pt. 505: 51-52 (July 1992) [hereinafter Indiv. Empl. Rts. Manual]. But see id. (showing that only 13 states recognize a cause of action for breach of the covenant of good faith and fair dealing in employment at will cases).

${ }^{6}$ Payne v. Western \& Atl. R.R., 81 Tenn. 507, 519-20 (1884), rev'd on other grounds, Hutton v. Watters, 132 Tenn. 527 (1915). 
principles of contract and tort, which are rooted in fundamental legal policies such as the binding obligation of representations, ${ }^{7}$ good faith and fair dealing, ${ }^{8}$ promotion of public policies, ${ }^{9}$ and protection against abusive action. ${ }^{10}$

The trend did not begin with the employment at will cases but can be traced back at least to the Equal Pay Act of 1963, ${ }^{11}$ Title VII of the Civil Rights Act of 1964 (Title VII), ${ }^{12}$ the Pregnancy Discrimination Act of 1978 (PDA) ${ }^{13}$ and the Age Discrimination in Employment Act of 1967 (ADEA). ${ }^{14}$ Other acts building upon this statutory trend included the Occupational Safety and Health Act of $1970(\mathrm{OSH}),{ }^{15}$ and the Employment Retirement Income Security Act of 1974 (ERISA). ${ }^{16}$ Moreover, even before the judicial sea change in employment at will, there was a number of little noted federal provisions protecting employees who reported violations of various statutes from discrimination in employment. ${ }^{17}$

7 See J. Peter Shapiro \& James F. Tune, Note, Implied Contract Rights to Job Security, 26 STAN. L. REV. 335, 337 (1974) (arguing that the common law principles of implied contract theory can be used to "safeguard legitimate employee interests against firing without cause"); Clare Tully, Note, Challenging the Employment-at-Will Doctrine Through Modern Contract Theory, 16 U. MICH. J.L. REF. 449, 450 (1983) (arguing for an implied contract theory that "both satisfies contractual requirements and protects the ... expectations of employees").

${ }^{8}$ See Note, Protecting at Will Employees Against Wrongful Discharge: The Duty to Terminate Only in Good Faith, 93 HARV. L. REV. 1816, 1844 (1980) ("The courts should imply a contract term allowing only good faith discharges, or create a tort duty that employers discharge only in good faith.").

${ }_{9}$ See Note, Protecting Employees at Will Against Wrongful Discharge: The Public Policy Exception, 96 HARV. L. REv. 1931, 1951 (1983) (arguing that the public policy exception should be expanded to protect employees from wrongful discharge).

${ }^{10}$ See Lawrence E. Blades, Employment at Will vs. Individual Freedom: On Limiting the Abusive Exercise of Employer Power, 67 ColuM. L. REv. 1404, 1421-27 (1967) (arguing that the law of torts provides an appropriate judicial means of protecting employees from abusive termination). For a discussion of the use of these common law principles generally, see Cornelius J. Peck, Penetrating Dotrinal Camouflage: Understanding the Development of the Law of Wrongful Discharge, 66 WASH. L. REV. 719 (1991); for a canvas of their application, see 2 HOWARD A. SPECTER \& MATTHEW W. FinkIN, INDIVIDUAL EMPLOYMENT LAW AND LITIGATION \$§ 15.01-.23 (1989).

1129 U.S.C. $\S 206(d)$ (1988).

1242 U.S.C. $\$ \S 2000 \mathrm{e}-2000 \mathrm{e}-17$ (1988).

${ }^{13} \mathrm{Id}$. $\$ 2000 \mathrm{e}(\mathrm{k})$.

1429 U.S.C. $\$ \$ 621-634$ (1988 \& Supp. II 1990).

${ }^{15} I d . \$ \S 651-678$.

${ }^{16} \mathrm{Id} . \S \S 1001-1461$.

17 See WILLIAM J. HollowaY \& MiCHAEL J. LEECH, EMPLOYMENT TERMINATION: RIGHTS AND REMEDIES 256-58, app. at 425-29 (1985) (citing various federal "antiretaliation statutes," including the Asbestos School Hazard Detection \& Control Act, 20 U.S.C. $\$ 3608$ (1988), the Surface Mining Control \& Reclamation Act, 30 U.S.C. $\$ 1293(\mathrm{a})$ (1988), and the Safe Drinking Water Act, 42 U.S.C. $§ 800 j-9(\mathrm{i})(1)$ 
The trend towards greater legal protection continues with a number of states enacting various types of "whistleblower" statutes, ${ }^{18}$ and Montana enacting a general statute protecting against unjust discharge. ${ }^{19}$ In addition, state laws prohibit the use of polygraphs, limit drug testing, permit employee access to personnel files, protect the confidentiality of employee records, require employers to provide nonsmoking work areas, ${ }^{20}$ protect employees from discharge because of garnishment, ${ }^{21}$ and require employers to notify employees of the presence of toxic chemicals. ${ }^{22}$ As some states experiment with such statutes, pressures for more comprehensive and effective federal statutes mount. At the federal level, Congress in 1988 enacted the Worker Adjustment and Retraining Notification Act (WARN), ${ }^{23}$ and in 1990 passed legislation prohibiting discrimination against the disabled, the Americans with Disabilities Act (ADA). ${ }^{24}$ Pregnancy leave proposals are on the immediate agenda, ${ }^{25}$ and a wide range of other statutes are on the horizon.

The trend toward greater judicial and legislative protection has deep roots in the failure of collective bargaining to provide protection through the contractual process. One of the premises of

(1988)); I SPECTOR \& FINKIN, supra note 10, 10.02 (stating that the National Labor Relations Board held that "an employee's ... efforts ... to enforce statutory provisions ... constitute[] protected ... activity").

${ }^{18}$ See STEPHEN M. KOHN \& MiCHAEL D. KOHN, THE LABOR LAWYER'S GUIDE TO THE RIGHTS AND RESPONSIBILITIES OF EMPLOYEE WHISTLEBLOWERS 17-72, 91-101 (1988) (discussing federal and state protection for employee whistleblowers and describing the scope of protected activity); Terry M. Dworkin \& Janet P. Near, Whistleblowing Statutes: Are They Working?, 25 AM. Bus. L.J. 241, 242 n.4 (1987) (citing statutes from California, Connecticút, Maine, Michigan, New Jersey, and New York).

19 See MONT. CODE ANN. §§ 39-2-901 to 39-2-914 (1991).

${ }^{20}$ See, e.g., Indiv. Empl. Rts. Manual, supra note 5, pts. 541-592, at 541:3, 545:31, $552: 5,556: 15,579: 2$ (citing a number of state statutes protecting individual employees).

21 See, e.g., CAL. LAB. CODE § 2929(b) (West 1989) (providing that no employer may discharge an employee by reason of the fact that her wages have been threatened to be garnished or subject to garnishment).

22 See ALASKA STAT. § 18.60.068(b) (1991) (requiring employer whose employees may be exposed to hazardous substances in the workplace to give various forms of notice).

2329 U.S.C. $\$ \S 2101-2109$ (1988) (requiring employers with more than 100 full time workers to give notice before plant closings and mass layoffs).

2442 U.S.C. \$§ 12101-12117 (Supp. II 1990).

25 The Family Medical Leave Act was passed by Congress in 1990, but vetoed by President Bush. See Helen Dewar, Senate Approves Family Leave Bill, WASH. POST, Aug. 12, 1992, at A9. A substantially similar bill is presently being considered in Congress. See id. 
the Wagner $\mathrm{Act}^{26}$ was that collective bargaining would equalize bargaining power sufficiently to enable employees to protect their interests through collective agreements without the aid of legislation prescribing terms of the employment relation. Collective bargaining, where it became established, proved itself capable of performing this function. It became apparent, however, after forty years of labor relations under the National Labor Relations Act that employer resistance to the establishment of collective bargaining had prevented it from serving this social purpose for the great majority of employees. Thus courts and legislatures have felt the pressure to fashion legal protection where collective agreements do not provide it. The prospect is that this pressure and the trend will continue. ${ }^{27}$

Primary attention, as this trend developed, has inevitably focused on what substantive employment rights should be legally recognized and enforced. The debate at present is focused on what protection employees should have against unjust discharge; what protections employees should have against invasions of privacy; what protections employees should have when plants close; what toxic substances should be prohibited in the workplace; what, if any, notice should employees have of other toxic substances to which they are exposed; when should drug tests be allowed; and what medical insurance should an employer be required to provide.

A secondary but significant question, which has received less attention, addresses what kinds of procedures and remedies should be provided to enforce those rights. ${ }^{28}$ The truism that there is no right without a remedy can be more usefully stated in the form that the reality of the right depends on the effectiveness of the remedy. My purpose here is to pass over the substantive debate and, in a preliminary fashion, inquire how the procedures and remedies for enforcing individual employment rights might best be designed. We have now had substantial experience with enforcing a variety of those rights. It will be useful to examine some of the procedures and remedies used in enforcing these rights to learn the lessons which they may offer as to their effectiveness. We may be able to

2649 Stat. 372 (1935) (codified as amended at 29 U.S.C. $\$ \S 151-169$ (1988)).

${ }^{27}$ See Clyde W. Summers, Labor Law as the Century Turns: A Changing of the Guard, 67 NEB. L. REV. 7, 16-17 (1988) (arguing that passage of recent protections creates a multiplier effect, generating demand to protect additional employee rights).

${ }^{28}$ For a comprehensive discussion of the potentials and problems of unions enforcing these rights, see Robert J. Rabin, The Role of Unions in the Rights-Based Workplace, 25 U.S.F. L. REV. 169 (1991). 
identify some preliminary guidelines for restructuring the procedures and remedies enforcing existing rights, and for establishing more effective enforcement processes for future rights.

There is no intent or expectation that a single procedure and remedy can be designed for all individual employment rights. Procedures and remedies must be tailored to fit the shape of the substantive right. However, certain factors common to most or all employment relations raise common considerations in evaluating and designing remedies. First, the employment relation is a dominant-servient relation, and any effort by an employee to enforce rights against the employer functions in a context of inequality of both power and resources. Second, individual employees acting to enforce their rights are likely to be first-time players, with no expectation of becoming a repeat player. The employer, on the other hand, will be or expect to be, a repeat player. This increases the employer's advantage both in experience and incentive to deploy resources in the contest. Third, legal protection of any employment right is potentially applicable to millions of employees in hundreds of thousands of workplaces, and this may generate thousands or even millions of claims requiring mass administration of justice. These and other common factors should lead to some common guidelines for enforcement of various employment rights, although the rights to be enforced may be quite diverse.

My purpose here is to describe briefly the different procedures and remedies used for protecting certain individual employment rights, and to evaluate each in a preliminary fashion for its effectiveness in protecting those rights. Examination will be limited to remedies for various forms of wrongful dismissal under the common law, the National Labor Relations Act, and the Civil Rights Act of 1964, for underpayment of wages under the Fair Labor Standards Act, for violation of health and safety standards under the Occupational Safety and Health Act, and for injuries on the job. These involve different types of employment rights-the right to job security, the right to minimum wages, the right to physical integrity, and the right to compensation for work injuries. By examining enforcement of this range of employment rights, it may be possible to draw some tentative guidelines which might have general applicability toward designing procedures and remedies for present and future employment rights. Beyond these tentative guidelines, I will suggest some structural proposals for enforcement of employment rights generally. 
The analysis and evaluation here can be no more than preliminary, for few empirical studies have been made of the effectiveness of any of these procedures and remedies. The best that can be done for now is to draw on incomplete data, random facts, anecdotal evidence, and impressionistic experience of how various procedures and remedies work. Detailed studies might disclose different strengths and weaknesses than those projected. It should be useful, however, to develop at least a preliminary framework of analysis and offer some tentative conclusions which might be more critically examined by empirical studies and further consideration.

\section{REMEDIES FOR RIGHTS TO JOB SECURITY}

Job security is a primary area of individual employment rights. It includes the currently volatile field of employment-at-will; discrimination because of union membership, race, sex, age and handicap; polygraph and drug testing; parental leave and plant closing, as well as seniority rights and discipline for cause under collective agreements. The focus here is limited to three major procedures and remedies presently available.

\section{A. Common Law Remedies}

An appropriate place to start our inquiry is with the common law remedies for wrongful dismissal, where courts have developed exceptions to employment at will. In principle, the remedy depends on the legal theory used to uphold the employee's claim. If the dismissal is found to violate the contract of employment implied from provisions in an employee handbook, representations made at the time of hiring, or other implied or express promises, then the remedies are limited to those traditionally available for breach of contract. If, on the other hand, the dismissal is found to be violative of public policy, retaliatory, malicious, or abusive, the remedies extend to those traditionally available in tort. In practice, the lines are not always so neatly drawn. In Monge v. Beebe Rubber Co. ${ }^{29}$ the court stated that the termination was wrongful if "motivated by bad faith or malice or based on retaliation," but limited damages to loss of back pay. In Cleary v. American Airlines, Inc., ${ }^{30}$ the court invoked the covenant of good faith and fair dealing,

29316 A.2d 549, $551-52$ (N.H. 1974).

${ }^{30} 168$ Cal. Rptr. 722, 728-29 (Ct. App. 1980) (quoting Comunale v. Traders \& Gen. Ins. Co., 328 P.2d 198, 201 (Cal. 1958)). 
"[which] is ... implied in every contract," but held that the dismissed employee might recover punitive damages.

When the court treats the dismissal as a breach of the employment contract, damages are customarily limited to loss of earnings and pension rights. This may include loss of future earnings, although due to the difficulty in determining these, they may be excluded or conservatively estimated. Furthermore, discharged employees are not ordered reinstated in their jobs, because the courts mechanically follow the outdated aphorism that equity will not order specific performance of a personal service contract. ${ }^{31}$ Additionally, damages for disruption of personal life, emotional distress and other consequential injuries are seldom included, and punitive damages are rarely allowed in breach of contract cases. ${ }^{32}$ In real terms, employees are seldom made whole, even for all economic loss. Damages in contract are substantial only when the discharged employee is in the upper salary brackets. Thus, in Monge, the damages recovered by a wrongfully discharged hourly wage worker were only approximately $\$ 1500 ;^{33}$ but in Toussaint $v$. Blue Cross $\mathcal{E}$ Blue Shield, a middle management employee recovered approximately $\$ 73,000$. $^{34}$

When the court treats the dismissal as a tort, the damages may be many times greater, for they may include, in addition to economic loss, damages for emotional distress and punitive damages. In Gates v. Life of Montana Insurance Co., the Montana Supreme Court found a violation of the covenant of good faith and fair dealing and upheld an award of $\$ 1891$ compensatory damages and $\$ 50,000$ punitive damages. ${ }^{35}$ In another case, the same court upheld an award of $\$ 94,170$ for economic damages, $\$ 100,000$ for

${ }^{31}$ See 5A ARThUR L. CoRbIn, CoRbIn ON ConTracts $\$ 1204$ (1964); see also Martha S. West, The Case Against Reinstatement in Wrongful Discharge, 1988 U. ILL. L. REV. 1, $28-40$ (noting the limitations of the reinstatement remedy).

32 Most states treat the covenant of good faith and fair dealing as grounded in contract. Some states, however, treat it as a tort, entitling the plaintiff to emotional distress and punitive damages. See 1 SPECTER \& FINKIN, supra note 10, § 10.52; 2 SPECTER \& FINKIN, supra note 10, § 15.11; see also Michael H. Cohen, Comment, Reconstructing Breach of the Implied Covenant of Good Faith and Fair Dealing As A Tort, 73 GAL. L. REV. 1291, 1291 (1985) ("Tort victims may recover all consequential damages flowing from the wrongful act. Parties injured in contract, on the other hand, face several obstacles to full recovery.").

${ }^{33}$ Monge, 316 A.2d at 552.

34292 N.W.2d 880, 883 (Mich. 1980). In a companion case, Ebling $v$. Masco Corp., the plaintiff recovered $\$ 300,000$ because the discharge left him ineligible to exercise a stock option. Id. at 897 n.39.

${ }^{35}$ See 668 P.2d 213, 214, 216 (Mont. 1983). 
emotional distress and $\$ 1,300,000$ in punitive damages. ${ }^{36}$ In California, where violation of the covenant of good faith and fair dealing was, until 1988, treated as a tort, ${ }^{37}$ there were numerous multi-million dollar verdicts. A study by the Rand Institute for Civil Justice of 120 cases which went to jury verdicts between 1980 and 1986 found the average verdict for winning plaintiffs to be nearly $\$ 650,000,9^{38}$ with the ten highest verdicts averaging nearly $\$ 4$ million. ${ }^{39}$

These numbers provide a highly misleading picture of the remedies obtained by wrongfully discharged employees. First, the average is distorted by the few multi-million dollar verdicts. The Rand Study showed a median verdict of approximately $\$ 177,000 .^{40}$ Second, post-trial appeals and settlements substantially reduce the final payments. The median award is reduced by approximately $23 \%,{ }^{41}$ making the median final payment for those who win about $\$ 136,000 .^{42}$ Third, lawyers' contingency fees of $40 \%$, and out of pocket expenses of $5 \%$ to $10 \%$ routinely absorb approximately $45 \%{ }^{43}$ of the final payment, leaving the net median recovery of wrongfully discharged employees who win jury verdicts at about $\$ 74,500$. $^{44}$

More marked and more significant is the disparity in recovery

${ }^{36}$ See Flanigan v. Prudential Fed. Sav. \& Loan Ass'n, 720 P.2d 257, 258 (Mont. 1986).

37 In Foley v. Interactive Data Corp., 765 P.2d 373, 395 (Cal. 1988), the California Supreme Court held that tort remedies would not be extended to breach of the implied covenant of good faith in wrongful discharge cases. Recovery would be limited to contractual damage. $I d$. at 401 .

${ }^{38}$ See James N. DeRTouzos ET al., The Legal and EConomic ConseQuenCes of WRONGFUl TERMINATION 44 (1988) [hereinafter THE RAND STUDY]. A larger study, based on 223 cases in California, found a substantially lower average jury verdict of $\$ 486,812$. David J. Jung \& Richard Harkness, The Facts of Wrongful Discharge, 4 LAB. LAW. 257, 259, 260 (1988) [hereinafter The Facts].

${ }^{39}$ THE RAND STUDY, supra note 38, at 26-27.

${ }^{40} I d$. at 26 (noting that one-half of the awards were smaller than the cited figure). The study by Jung and Harkness shows a lower median verdict of approximately $\$ 124,000$. The Facts, supra note 38 , at 260 .

41 See THE RAND STUDY, supra note 38, at 35 (given that the payout ratios for the second and third quartiles are .79 and .75 respectively).

${ }^{42}$ See id. (applying the $23 \%$ reduction to the $\$ 177,000$ median figure).

${ }^{43} \mathrm{Id}$. at 37 (noting that over $50 \%$ of attorneys charged a flat $40 \%$ fee, whereas about $10 \%$ charged over $40 \%$ ).

${ }^{44} I d$. at 39. This net median recovery, based on the Rand Study, is probably high. Jung and Harkness found a median award of about $\$ 124,000$. The Facts, supra note 38 , at 260 . With a reduction of $23 \%$ for post-trial appeals and settlements as derived from the Rand Study, the median final payment by an employer would be about $\$ 95,000$, and after payment of lawyer fees and costs of $45 \%$ would be about $\$ 51,000$. 
among winning plaintiffs. The individuals in the lowest quartile of winning plaintiffs end up with net payments of less than $\$ 25,000$, while those in the highest quartile end up with net payments of approximately $\$ 550,000 .{ }^{45}$ Plaintiffs in the top ten cases netted payments of more than $\$ 900,000$. $^{46}$

Whereas the figures cited in the previous paragraph refer to recoveries obtained by those discharged employees who win jury verdicts, more than a third of those who end up in court lose on preliminary motions before getting to the jury, ${ }^{47}$ and about a third of those who do get to the jury do not win a verdict. ${ }^{48}$ The net result is that more than half of those discharged employees whose cases are judicially resolved obtain nothing. This situation prevailed in California, at a time when California was considered the Eden for discharged employees, both in terms of substantive legal rules protecting employees and the generosity of its damage awards. It is generally accepted that discharged employees in other states win much less frequently, and those who win obtain much smaller recoveries.

Most cases, of course, do not end up in court. Rather, they are settled prior to adjudication. One survey estimated that $95 \%$ of the cases are settled, ${ }^{49}$ but anecdotal evidence suggests that the settlement rate may be substantially smaller in other states. No hard data exist as to settlement amounts, nor at what point cases are settled. Some data and anecdotal evidence indicate that employers substantially undervalue cases, especially during a period when recoveries are becoming more frequent and awards are escalating. ${ }^{50}$ Even plaintiffs seem to undervalue cases where large awards are conceivable. Overall, plaintiffs probably recover substantially less than half as much if the case is settled than if it goes to court and is won. ${ }^{51}$

45 The RAND STUDY, supra note 38 , at 41 .

16 See id. at 41.

47 This estimate is based on Jung and Harkness's data on the percentage of jury verdicts won and an estimate of cases in which plaintiffs who go to court ultimately prevail. See The Facts, supra note 38, at 260 (noting that plaintiffs win $70 \%$ of jury trials, and $45 \%$ of all cases judicially resolved).

48 See THE RAND STUDY, supra note 38, at 25 (32.5\%); The Facts at 260 (30\%).

19 See THE RAND STUdy, supra note 38, at 48.

${ }^{50}$ See generally id. at $41-43$ (noting that for the largest awards, "defendants could have reduced their payments by an average of over two-thirds by agreeing to meet plaintiff demands").

51 A mail survey of lawyers involved in settlements indicated that $95 \%$ of all wrongful termination cases are settled for amounts averaging $\$ 30,000$. $I d$. at 48 . In 
Two stark facts emerge from these data. First, most wrongfully discharged employees obtained modest or wholly inadequate awards, even in California, where the substantive legal rules made tort remedies available in most cases. The majority of plaintiffs are executives or middle management employees, with average salaries, in the early $1980 \mathrm{~s}$, of $\$ 36,000$. $^{52}$ A recovery of $\$ 74,500,{ }^{53}$ which in most cases includes damages for emotional distress and punitive damages, amounts to only two years' lost salary. If the suit is in contract, the award is only for loss of earnings. After payment of legal costs, the wrongfully discharged employee recovers only a little more than one-half of her direct economic loss. This recovery typically comes three to five years after the discharge, with no interest on the lost earnings.

Second, there is a wide disparity in the amount recovered by discharged employees, which often bears little relation to economic loss. The amount of recovery depends largely on the amount awarded for emotional distress and punitive damages. ${ }^{54}$ These awards may range from double to twenty times the economic loss. ${ }^{55}$ Bringing suit for wrongful discharge, even in a state as favorable as California before 1988 , is a lottery in which many receive nothing, most receive less than their economic loss, while a lucky few win the jackpot.

A significant consideration in measuring the effectiveness of remedies is the high cost of litigation. Plaintiff lawyers' fees, based on a $40 \%$ contingency fee, ${ }^{56}$ would average more than $\$ 119,000$ for cases won at trial and approximately $\$ 80,000$ for all cases tried. ${ }^{57}$ Plaintiff lawyers, however, are engaged in the same lottery as the discharged employees. For cases in the lowest quartile, the average fee will be only $\$ 14,000$ for cases won at trial. ${ }^{58}$ Even in the median winning case, though the fee may be as high as $\$ 54,000,{ }^{59}$ one-third of the cases tried by a jury are lost. ${ }^{60}$ Cases

contrast, the average jury award, excluding defense judgments, but including punitive damages, was $\$ 646,855$. Id . at 25.

52 See id. at $20-21$.

53 See suipra note 44.

54 See THE RAND STUDY, supra note 38, at 25; The Facts, supra note 38 at 264-65.

55 See supra notes 35-36 and accompanying text.

56 See, e.g., THE RAND STUDY, supra note 38 , at 41 (stating that the contingency fees in the studied cases were between $37 \%-39 \%$ ).

${ }^{57} \mathrm{See} i d$. at 40 . In measuring legal fees, the relevant amount is the average recovery, not the median recovery.

${ }^{58}$ See id. at 41.

${ }^{59}$ See supra notes $41-43$ and accompanying text. A $40 \%$ contingency fee is applied 
in the highest quartile, however, produce an average fee of $\$ 354,000$, and the ten highest cases produced an average fee of $\$ 561,000$. $^{61}$

High litigation costs undercut the usefulness of the remedy for many discharged employees. Although no systematic data are available on the legal costs of bringing a case to trial, plaintiff lawyers have stated that their costs, including their time, range from $\$ 5000$ to $\$ 25,000$, and that there is seldom serious effort made to settle much before trial. ${ }^{62}$ Trying the case similarly may add another $\$ 5000$ to $\$ 25,000 .^{63}$ Where recovery is limited to contract damages, prospective litigation costs may easily exceed potential recovery, except for high salaried employees. Therefore, even if the dismissal is clearly wrongful and success in litigation certain, the lawyer may not be able to afford to take the case on contingency, if the employer is likely to force the case to trial. If suit can be brought in tort, with lost earnings embellished by emotional distress and punitive damages, recovery must be above $\$ 60,000$ to support the costs of litigation, particularly if the employer escalates those costs with extensive discovery, interrogatories, depositions, and preliminary motions. ${ }^{64}$ Where the prospect of victory is uncertain, as it is in most cases, a lawyer will be unwilling to take the case on a straight contingency basis unless there is the prospect of an early settlement or recovery substantially above the median to appeal to the lawyer's gambling instincts.

Because of litigation costs, all but middle and upper income employees are largely foreclosed from any access to a remedy for wrongful dismissal. This is apparent from the reported cases. Relatively few plaintiffs are hourly wage or clerical workers; the large majority are professional employees or are in middle and upper management. ${ }^{65}$ Middle income employees with contract

to the $\$ 136,000$ median award.

${ }^{60}$ See THE RAND STUDY, supra note 38, at 25.

61 See id. at 41 . These figures give an inaccurate impression of the plaintiff lawyer's income, for although two-thirds of the cases brought to trial are won, only half the cases not settled but judicially resolved are won. For all cases judicially resolved, the plaintiff's lawyer can therefore expect an average fee of $\$ 60,000$, while the average fee is $\$ 7000$ for cases in the lowest quartile and $\$ 176,000$ for cases in the upper quartile. Id.

62 These figures are based on estimates derived from numerous conversations I have had with practitioners over the past few years.

63 See supra note 62.

64 See supra note 62.

65 See THE RAND STUDY, supra note 38, at 21. 
claims or modest tort claims who cannot make a substantial payment in advance will be discouraged by lawyers from pursuing their claims. Lower income employees without substantial tort claims will have difficulty finding a lawyer. ${ }^{66}$

The consequences of high litigation costs for employers are different, but no less troublesome. When an employee makes a claim of wrongful discharge, the employer must either make an early settlement, regardless of the merits of the claim, or face the immediate prospect of heavy legal costs. The Rand Study found that pre-trial defense legal fees averaged $\$ 25,000^{67}$ and for cases going to trial the defense legal fees averaged approximately $\$ 80,000 .^{68}$ The defense fees, usually billed at an hourly rate, are substantially the same whether the case is won or lost.

In California, it is claimed that many questionable wrongful discharge suits are threatened or brought in the hopes that the employer will settle to avoid these costs. This pressure continues, for if the case is not settled and is brought to trial, the legal fees for each case on average cost the employer $\$ 80,000,{ }^{69}$ with median legal costs of $\$ 65,000 .^{70}$ Because the employer wins only one-third of the cases which go to trial, the cost of legal fees for all cases at the median which the employer wins becomes $\$ 195,000$, more than the final estimated payment in the median case of $\$ 136,000 .^{71}$ From this perspective it would benefit the employer in most cases to settle rather than to contest the cases, ${ }^{72}$ and some employers do follow this principle. This, however, invites more questionable claims. Furthermore, the employer knows that in most cases the discharged employee cannot afford to pursue his suit or obtain a lawyer who will take the case on a contingency basis. By vigorously contesting every case, an employer can gain a reputation which will discourage or foreclose employees, even employees with good

${ }^{66}$ In my conversations with them, lawyers experienced in handling wrongful discharge cases have explained that if the potential claim is less than $\$ 25,000$, they will not take the case, or at most will attempt to negotiate a settlement.

67 See THE RAND STUDY, supra note 38, at 48.

68 See id. at 37. Where recovery is in the lowest quartile-below $\$ 25,000-$ defense legal costs average $\$ 51,000$; where recovery is in the upper quartile-approximately $\$ 560,000$-defense legal fees average $\$ 111,000$. Id. at 41 .

${ }^{69}$ Id. at 37.

70 Id. at 38 .

71 See supra notes $42 \& 60$ and accompanying text.

72 See THE RAND STUDY, supra note 38 , at 42,45 (noting that in $20 \%$ of all cases, legal fees exceed the offer to settle, and that "[c]onsidering legal fees, most defendants would be better paying the demands rather than going to trial"). 
claims, from bringing suit. There seems to be an increasing number of employers following this strategy, except perhaps in cases where the discharge was so clearly wrongful that liability is beyond doubt. The consequence of this strategy is effectively to deny remedies to many employees who were, in fact, wrongfully discharged.

The high costs of litigation in these cases raise a serious social question concerning transaction costs. In the median case, the wrongfully discharged employee ends up with a net payment of less than $\$ 74,500 .^{73}$ For every wronged employee thus compensated, the employer pays legal fees of one and a half the estimated median fee, or about $\$ 97,500,{ }^{74}$ and the plaintiff's lawyer obtains $\$ 54,000,{ }^{75}$ for a total of about $\$ 151,500$ in fees. To this figure, one must add court and out of pocket costs to both sides of approximately $\$ 10,000 .^{76}$ In short, more than $\$ 160,000$ may be spent to transfer less than $\$ 74,500$ of compensation to a wronged employee. This entire cost is ultimately borne by the employer while the wronged employee goes undercompensated. This is scarcely a legal remedy process but rather a redistribution device which enriches lawyers at the expense of both the employer and the employee.

An important measure of a remedy is its effectiveness in deterring conduct which the law considers wrongful. Large jury verdicts, particularly when widely publicized, certainly serve the useful purpose of deterring some employers from discharging employees except for good and demonstrable cause. Even though the large verdicts are few and random, their notoriety gives them substantial impact. ${ }^{77}$ Many companies have improved their internal procedures and monitor discharges more carefully, with a few having established binding arbitration for non-union employees. ${ }^{78}$ However, the dominant employer response, motivated or

73 See supra note 44 and accompanying text.

74 THE RAND STUDY, supra note 38 , at 40; see also supra note 60.

75 See supra note 59 and accompanying text.

${ }^{76}$ This figure represents an estimate based on conversations I have had with practitioners.

77 See Cliff Palefsky, Wrongful Termination Litigation: "Dagwood" and Goliath, 62 Mich. BUS. L.J. 776, 776 (1983) (citing a study by a San Francisco law firm showing that $90 \%$ of wrongful dismissal suits resulted in plaintiff verdicts averaging $\$ 450,000$ ); Jeff B. Copeland, The Revenge of the Fired, NEwSWEEk, Feb. 16, 1987, at 46, 47 (reporting that $72 \%$ of employees who sued their bosses for being fired recovered an average of $\$ 582,000$ ).

${ }^{78}$ Among major companies providing binding arbitration for non-union employees are Montgomery Ward, Duke University, Gannett Corporation, and Meijer, 
encouraged by lawyers and employment consultants, is not so much to avoid unjust discharges, but to suit up in "legal armorplate" to defend against judicial exceptions to employment at will. ${ }^{79}$ Most of this legal advice emphasizes writing explicit "at will" clauses into all hiring documents and contracts, purging handbooks of all references to job security, and instructing supervisors not to make any representation as to how long a job may last or how long the employee will be kept. The focus is almost entirely on the employment contract, and protects only against contract actions in which damages are limited to lost earnings. This touted "armorplate" gives little or no protection against tort actions with their added liability for emotional distress and punitive damages. ${ }^{80}$ It may create risks by giving supervisors a false sense of security that they can discharge any employee at any time for any reason.

The notoriety of large jury verdicts, while deterring some employers from unjustified dismissals, incites discharged employees and their lawyers to bring suit even though their cases have little merit. $^{81}$ If the case is one which may stir the judge or jury, they are encouraged to gamble, hoping that legal action will produce a

Inc. See Thomas J. Barnes \& Jeffrey S. Rueble, Making Wrongful Discharge Right, 66 MICH. B.J. 128 (1987). Other companies adopting similar procedures include Trans World Airlines, American Optical Company, Polaroid, and Pittsburgh Plate Glass, see Jack Stieber \& Michael Murray, Protection Against Unjust Discharge: The Need for a Federal Statute, 16 U. MICH. J.L. REF. 319, 326 (1983), as well as Ohio Power Company, Kraft, Inc., and Northrup Corporation, see Edward B. Shils, A Review of Possible Alternatives to Eliminate the "Employment-at-Will" Doctrine with Special Emphasis on the Growing Field of Voluntary Arbitration 54-58, 67-72, 84-87 (Apr. 30, 1986) (unpublished manuscript, on file with author).

${ }^{79}$ See generally Bennett W. Root, Jr., Defending Against Wrongful Termination Before and After Litigation, in EMPLOYEE TERMINATION HANDBOOK 61-89 (Jeffrey G. Allen ed., 1986) (discussing steps employers can take to minimize wrongful discharge litigation); Richard G. Moon, Avoiding Liability for Wrongful Discharge-Management Planning and Litigation Tactics, 62 MICH. B.]. 780 (1983) (discussing both pre-litigation efforts and litigation techniques used to avoid liability for discharging employees); Alan $F$. Westin, Employer Responses to New Judicial Rulings on At-Will Employment: A Warning About the "Legal Armorplate" Approach, 36 PRoc. N.Y.U. ANN. NAT'L CONF. ON LAB. 13-1 (1983) (discussing how the "legal armorplate" approach is bad from both the labor relations and legal strategy viewpoints).

${ }^{80}$ See Julius M. Steiner \& Allen M. Dabrow, The Questionable Value of the Inclusion of Language Confirming Employment-at-Will Status in Company Personnel Documents, 37 LAB. L.J. 639, 642 (1986); Patricia M. Lenard, Note, Unjust Dismissal of Employees At Will: Are Disclaimers a Final Solution?, 15 FORDHAM URB. L.J. 533, 562 (1987). See generally Westin, supra note 79, at 13-21 to 13-23 (discussing why the "legal armorplate" approach is bad legal strategy).

81 See Arthur S. Leonard, A New Common Law of Employment Termination, 66 N.C. L. REV. 631,684 (1988). 
silk purse full of gold from a sow's ear.

One of the less visible contributions of common law remedies for wrongful dismissal, and particularly tort liability with its potentially massive judgments, has been to reduce employer opposition to legislation providing broader protection against unjust discharge with remedies limited to economic loss. Without the threat of tort liability, employers' opposition to any legislation providing general protection has been, and would continue to be, adamant. It is no accident that the states in which such proposals have been taken seriously are ones in which the courts have upheld large awards. Indeed, the Montana statute which prohibits discharge without "just cause" was a reaction to court decisions which caused employers to prefer legislation to living under the Sword of Damocles of massive tort liability. ${ }^{82}$ At the same time, the reality of large recoveries creates a counterforce resisting legislation which broadens protection while limiting damages to economic loss. In California, where plaintiffs have won large awards, determined opposition to legislation has come from the plaintiff's bar, which profits from litigation-particularly from large recoveries for emotional distress and punitive damages. ${ }^{83}$

No studies comparable to those made in California have been made in other states, but the pattern appears substantially the same,

${ }^{82}$ See generally id. at 663-71 (outlining the Montana statute and discussing the Montana Supreme Court termination decisions that preceded it); Jonathan Tompkins, Legislating the Employment Relationship: Montana's Wrongful-Discharge Law, 14 EMPLOYEE REL. L.J. 387, 392 (1988) (discussing the political environment in which Montana's wrongful discharge legislation was drafted). The political reaction in California took a different turn. The notoriety of large tort verdicts helped fuel the move to remove, by referendum, members of the California Supreme Court seen as responsible for the decisions which led to the large verdicts; three judges were removed. See Arbitration Holds Promise for Employers Who Want to Stem Wrongful Discharge Suits, Daily Lab. Rep. (BNA) No. 219, at A-5 (Nov. 13, 1986), available in LEXIS, Nexis Library, Omni File (noting that the denial of reconfirmation by voters of Chief Justice Rose Elizabeth Bird and associate justices Joseph Grodin and Cruz Reynoso could have an impact on future wrongful discharge awards). Their newly appointed replacements promptly eliminated the common law tort remedies for breach of the covenant of good faith and fair dealing, reasoning that in the employment relationship the covenant was fundamentally contractual. See Foley v. Interactive Data Corp., 765 P.2d 373, 401 n.42 (Cal. 1988) (disapproving previous appellate cases permitting causes of action in tort for breach of the implied covenant).

${ }^{83}$ See generally William B. Gould, IV, Stemming the Wrongful Discharge Tide: A Case for Arbitration, 13 EMPLOYEE REL. L.J. 404, 405-06, 414-15 (1987) (citing examples of large jury verdicts for California plaintiffs, and explaining that lawyers who represent these employees would not embrace arbitration as an alternative to the existing system). 
with the exception that in other states plaintiffs win less often. Jury verdicts may be smaller in other states, but the Montana experience suggests that multi-million dollar verdicts are not the product of California sun or soft-headedness.

Common law remedies for wrongful discharge, however "wrongful" is substantively defined, have little to commend them. The limited in terrorem effect of large verdicts and potential legal costs may induce some employers to change their internal procedures or to be more circumspect in dismissing employees, but other employers try to shield themselves with "legal armorplate" and contest every lawsuit, no matter how legitimate the claim. Most wrongfully discharged employees who win in court, however, are under-compensated for their economic loss, even when they recover punitive damages. Where recovery is only in contract, they at best end up with little more than half their lost earnings. Employees whose potential recovery is not large have difficulty finding a lawyer on a contingency basis. Likewise, most lack the resources to pay hourly rates and legal costs in advance. In states where employees win less often than in California, legal costs cause most wrongful discharges to go unremedied. For employers, the legal costs in the majority of contested cases are as much as or more than the award paid over to the winning plaintiffs and their lawyers. The result is that in most cases the total legal cost of litigating these claims is four or five times the amount received by the wronged employee. Except from the narrow perception of the legal profession, this is gross social wastage.

\section{B. National Labor Relations Act Remedies}

Remedies for the individual employee under the National Labor Relations $\mathrm{Act}^{84}$ provide a sharp contrast to common law remedies. In the abstract, the procedures and remedies seem nearly ideal from the standpoint of an employee who suffers employment discrimination due to union activity. ${ }^{85}$

An employee who believes she is wronged needs simply to file a charge with the Regional Office of the National Labor Relations Board. She incurs no legal costs because the General Counsel acts

8429 U.S.C. $§ \S 141-187$ (1988 \& Supp. 1990).

85 Over one half of the charges filed with the National Labor Relations Board against employers are for illegal discharge or other discrimination against employees in violation of Section 8(a)(3). See 55 NLRB ANN. REP. 6 (1990). 
as investigator, conciliator and prosecutor. If the Board finds a violation, the General Counsel handles all appeals, even to the Supreme Court. ${ }^{86}$ The standard remedy for a discharged employee is reinstatement with back pay, compensating her for all loss of earnings. ${ }^{87}$

The administrative process is designed not to discourage employees who feel wronged from seeking help, but to weed out worthless cases at an early stage, simplify procedures, and minimize legal costs. Separate datum is not available on how many discharged employees go to the Board for help, but less than $6 \%$ of all inquiries in the Regional Offices result in charges being filed. ${ }^{88}$ When a charge is filed, the Regional Office investigates to determine the merits of the charge. After investigation, nearly two-thirds of all charges against employers are either withdrawn by the charging party or dismissed by the Regional Director as lacking merit. ${ }^{89}$ If the case has merit the Regional Office then attempts to conciliate or settle the remaining cases before issuing a complaint. $^{90}$ The end result is that nearly $87 \%$ of all charges against employers are disposed of before a complaint is issued. ${ }^{91}$ This disposition is accomplished within a median time of forty-five days after the filing of the charge. ${ }^{92}$ Efforts to settle continue after the complaint is issued so that only $4 \%$ of all charges go to a hearing

${ }^{86}$ After a complaint is issued, the charging party (usually a union) may intervene and become a party to the proceedings. If the Board rejects the General Counsel's position, in whole or in part, the intervenor may petition for review in the Court of Appeals. The intervenor then can petition for certiorari in the Supreme Court from an unfavorable decision of the Court of Appeals. See UAW v. Scofield, 382 U.S. 205, 208 (1965) (holding that the successful charged party in NLRB proceedings has the right to intervene in the appellate proceedings brought by the unsuccessful charging party, as well as in the appellate review); Peter M. Appleton, Note, Judicial Retraction of Standing Limitations in Review of NLRB Actions: UAW v. Scofield, 13 UCLA L. REV. 1408, 1417-18 (1966) (discussing the limits and the potential for expansion of the Supreme Court's Scofield decision).

${ }^{87}$ See ROBERT A. GORMAN, BASIC TEXT ON LABOR LAW: UNIONIZATION AND COLLECTIVE BARGAINING 138 (1976).

${ }^{88}$ NLRB General Counsel's Quadrennial Report for FY 1984 Through FY 1988, 130 Lab. Rel. Rep. (BNA) 465, 472 (Apr. 17, 1989) [hereinafter NLRB General Counsel's Quadrennial Report].

${ }^{89}$ See 55 NLRB ANN. REP., supra note 85, at 155 (indicating that $30.9 \%$ of the charges are withdrawn and $35.7 \%$ dismissed before a complaint is issued).

${ }^{90}$ See id. at 5. In fact, $21 \%$ of the cases are settled before a complaint is issued. See id. at 154. This figure includes all unfair labor practices. Discriminatory discharges are not separately tabulated.

\footnotetext{
91 See id. at 157.

92 See id. at 8.
} 
before the Administrative Law Judge (ALJ). ${ }^{93}$

The procedure before the ALJ is relatively simple, compared with court litigation, without the burdensome proliferation of interrogatories, depositions discovery, and pre-trial motions. More than half of the cases heard by an ALJ end there, either by acceptance of his recommended findings and order, or by settlement. Less than $3 \%$ of all charges result in contested Board decisions. ${ }^{94}$

The time required to process cases significantly affects the effectiveness of the remedy. The median time between receiving a charge and the issuing a complaint is forty-eight days; from issuing a complaint to the close of an administrative hearing is 154 days; from the close of the hearing to the ALJ's decision is 155 days; and from that date to the date of the Board decision is 314 days. ${ }^{95}$ Overall, from the date of the filing a charge to the date of a Board decision, the median time is 688 days. ${ }^{96}$ If the case is appealed to the Court of Appeals, another one to three years are added. ${ }^{97}$

Although Board procedures are regularly criticized for their slowness, ${ }^{98}$ the time taken to resolve most cases is far less than in suits for wrongful discharge or violations of Title VII of the Civil Rights Act. Although median time figures conceal cases which drag for years, ${ }^{99}$ nearly $87 \%$ of all charges are in fact closed by withdrawal or dismissal within forty-eight days, and another $9.5 \%$ are settled before the administrative hearing begins or within 100

93 See id. at 211.

94 See id.

95 See id. at 196.

${ }^{96}$ See id.

97 Petitions for certiorari to the Supreme Court can add another year or two.

98 Numerous hearings have addressed the issue of delay in NLRB decision-making. See 1988 Oversight Hearing on The National Labor Relations Board: Hearing Before a Subcomm. of the House Comm. on Gov't Operations, 100th Cong., 2d Sess. (1988) [hereinafter 1988 Oversight Hearing]; Oversight of The National Labor Relations Board (Part 2): Hearing Before a Subcomm. of the House Comm. on Gov't Operations, 99th Cong., 2d Sess. (1986); National Labor Relations Board Case Backlog: Hearing Before a Subcomm. of the House Comm. on Gov't Operations, 98th Cong., 1st Sess. (1983).

${ }^{99}$ In 1987 , there were 300 cases which had been waiting for decision by the Board for more than two years, and 71 cases which had been waiting for more than five years. See 1988 Oversight Hearing, supra note 98 , at 38 (statement of James $M$. Stephens, Chairman of the National Labor Relations Board). The Board made a special effort to reduce "average" cases, but in July 1988 there were still 178 cases more than two years old and 36 cases more than five years old. See id. at 68-90 (statements of Rep. Tom Lantos, Chairman of the Employment and Housing Subcommittee and John Truesdale, Executive Secretary of the National Labor Relations Board). 
days. ${ }^{100}$ This contrasts with the common pattern of settling civil suits on the courthouse steps after four or five years of discovery, depositions and other pre-trial activities, with out-of-pocket expenses and the accumulation of billable hours.

In practice, however, the picture is not so idyllic. First, the Board is not always a sympathetic tribunal, for it has become highly politicized. ${ }^{101}$ The Board members and the General Counsel are frequently selected on the basis of their sympathies for the union or the employer. During the last twelve years most of the nominations have been of management lawyers whose sympathies run more to management than to the union or the individual employee. ${ }^{102}$ This shift influences, at least on the margin, the development of substantive rules, but more importantly it influences, in a subtle and

${ }^{100}$ See 54 NLRB ANN. REP. 157 (1989); supra note 95 and accompanying text.

101 See, e.g., Harry L. Browne, The National Labor Relations Board: Labor Law Rewritten, 49 A.B.A. J. 64, 64 (1963) (arguing that the NLRB "has relied on its own policy rather than the congressional policy in interpreting the law" (footnote omitted)); William N. Cooke \&c Frederick H. Gautschi, III, Political Bias in NLRB Unfair Labor Practice Decisions, 35 Indus. \& LAB. ReL. Rev. 539, 539 (1982) (presenting evidence that "strongly supports the popular belief that Board decisions are heavily dependent upon shifting political winds"); David L. Gregory, The National Labor Relations Board and the Politics of Labor Law, 27 B.C. L. REv. 39, 51-52 (1985) (noting that the Board does reflect contemporary political values, but arguing that these political choices can be "a positive, actualizing force"); Phil M. Landrum, The National Labor Relations Board's Repeated Record of Deliberate Distortion, 12 J. PUB. L. 239, 249 (1963) (arguing that the Board's decisions are continually biased and that the Board "respects neither the letter of the law nor the intent of Congress"); Lee Modjeska, The Reagan NLRB, Phase I, 46 OHo ST. L.J. 95, 96-98 (1985) (analyzing the decisions issued by the Reagan Administration Board and their impact on national labor policy); Mozart G. Ratner, Policy-Making by the New "Quasi-Judicial" NLRB, 23 U. CHI. L. REv. 12, 19-33 (1955) (examining the sweeping character of the policy changes made by the Board since the Republican administration elected in 1952 filled a majority of the seats with its own appointees); Clyde W. Summers, Politics, Policy Making and the NLRB, 6 SYRACUSE L. REV. 93, 107 (1954) ("It is natural and proper that with the change in political climate, there should be changes in the rules and decisions of the Board. However, the Board should keep within the broad limits of the basic statutory purposes."); Stephen C. Vladeck, The Nixon Board and Retail Bargaining Units, 61 CORNELL L. REV. 416, 416(1976) (arguing that " the Board clearly expressed the essentially antilabor bias that permeated substantial parts of the Nixon administration").

102 See The Failure of Labor Law-A Betrayal of American Workers: Report of the House Subcomm. on Lab.-Mgmt. Rel. of the House Comm. on Educ. and Lab., 98th Cong., 2d Sess. 14-16 (1984) (stating that because of the politicization of the Board, "the perception of a neutral and objective NLRB has been shattered"); Lawrence J. Cohen \& Victoria L. Bor, The National Labor Relations Act Under Siege: A Labor View of the Reagan Board, 31 Proc. ANN. INST. ON LAB. L. DEv. 4-1, 4-3 (arguing that the Reagan Board "is probably the most result-oriented, antilabor, and antiworker Board in the history of the Act"). 
invisible fashion, the weighing of conflicting evidence which is often crucial in individual discharge cases. ${ }^{103}$ It is true that most of the cases are resolved by the Regional Offices or by ALJs whose appointments are not so politicized, but the handling of cases at the regional level would seem to be inevitably influenced by the general attitudes as well as the directives and decisions of the General Counsel and the Board.

Second, although the employee escapes the costs of litigation, the price is that he loses control of the case. The decision on whether his case has merit and should be prosecuted is controlled by the Regional Director who follows the advice of the General Counsel. ${ }^{104}$ If the Regional Director refuses to issue a complaint, an appeal can be taken to the Office of Appeals, but this is largely a futile gesture because the Regional Director is reversed in less than $4 \%$ of the appealed cases. ${ }^{105}$ This might suggest that Regional Directors are liberal in issuing complaints in borderline cases, but the opposite is true. The "quality" of the Regional Office's work is measured by the percentage of complaints upheld by Board decisions. The General Counsel recently pointed with pride to the fact that, in 1988 , over $82 \%$ of the litigated cases were won in whole or in part. ${ }^{106}$

The employee who has a borderline or doubtful case will likely find herself among those two-thirds who are rejected after investigation, but with no hearing or opportunity to present her case fully. The rejection is final, for there is no judicial review of the General Counsel's refusal to issue a complaint. ${ }^{107}$ The employee's lack of access prevents Board and court consideration of arguments which

103 See, e.g., Cohen \& Bor, supra note 102, at 4-43 to 4-44. The following statistics are suggestive:

Charges v. employers sustained Charges v. employers dismissed Charges v. unions sustained Charges v. unions dismissed Employer-won representation appeals Union-won representation appeals

\begin{tabular}{ccc} 
Nixon-Ford & Carter & Reagan \\
\hline $86.6 \%$ & $85.7 \%$ & $56.8 \%$ \\
$13.4 \%$ & $14.3 \%$ & $43.2 \%$ \\
$72.8 \%$ & $75.0 \%$ & $84.6 \%$ \\
$27.2 \%$ & $25.0 \%$ & $15.4 \%$ \\
$35.6 \%$ & $44.4 \%$ & $74.5 \%$ \\
$64.4 \%$ & $55.6 \%$ & $25.5 \%$
\end{tabular}

${ }^{104}$ See 29 C.F.R. $\$ \$ 101.4-.8$ (1992).

${ }^{105}$ See NLRB General Counsel's Quadrennial Report, supra note 88, at 474.

106 See id. at 466.

107 See NLRB v. United Food \& Commercial Workers Union Local 23, 484 U.S. 112,128 (1987) (holding that a postcomplaint, prehearing informal settlement decision by the General Counsel is not subject to judicial review under the NLRA). 
would provide greater protection than existing precedent or new principles with which the General Counsel disagrees. For nearly twenty years after Steele v. Louisville $\mathcal{E}$ Nashville R.R., ${ }^{108}$ the General Counsel refused to issue complaints on behalf of black employees who claimed that they had not been fairly represented by their union. ${ }^{109}$ The Board was thereby prevented from considering whether this was an unfair labor practice. In 1962, as the result of a complaint issued on other grounds and then amended, the Board was confronted with the question and concluded that violation of the duty of fair representation was an unfair labor practice. ${ }^{110}$

Third, the remedy of reinstatement with back pay is less adequate than first appears. Reinstatement is apparently considered by most wrongfully discharged employees of no practical value. Board statistics show that in 1990 back pay was ordered for 16,000 employees, but less than 3300 were reinstated. ${ }^{111}$ The rest either settled for back pay without reinstatement or refused reinstatement.

Two factors deprive reinstatement of practical value for most employees. Unless they are reinstated quickly, many will have found another job which they will be reluctant to leave; a 1974 study found that $93 \%$ of those offered reinstatement within two weeks accepted it, but only $5 \%$ of those offered reinstatement after six months returned to their old jobs. ${ }^{112}$ Although the new job may pay less, the employee often prefers to remain there rather than return to a

108323 U.S. 192 (1944).

${ }^{109}$ See, e.g., Case No. K-811, 37 L.R.R.M. 1457 (BNA) (Mar. 22, 1956) (involving a refusal by the General Counsel to issue a complaint upon racial discrimination charges made by employees against several employers and unions); see also Joseph $\mathrm{L}$. Rauh, Jr., Civil Rights and Liberties and Labor Unions, 8 LAB. L.J. 874, 877 (1957) (noting that "the Board has refused to act in the matter of racial exclusion"); Michael I. Sovern, The National Labor Relations Act and Racial Discrimination, 62 ColuM. L. REV. 563, 591 n.107 (1962) (commenting on Case No. K-311 and Rauh's article).

110 See Miranda Fuel Co., 140 N.L.R.B. 181, 182, 190 (1962), enforcement denied, 326 F.2d 172 (2d Cir. 1963). The complaint alleged a violation of Section 8(a)(3) on the grounds that the union unilaterally controlled seniority, but by the time the case came to the Board, this theory had been thrown in question by the Supreme Court's decision in Local 357, Int'l Bhd. of Teamsters v. NLRB, 365 U.S. 667 (1961). See Miranda Fuel Co., 140 N.L.R.B. at 181-82. The Board then found a violation of Section $8(a)(1), 8(b)(1)(A)$, and $8(b)(2)$ and adopted a theory of fair representation. See id. at 190.

111 See 55 NLRB ANN. REP., supra note 85, at 143-44 (indicating that back pay was ordered for 16,413 workers, 4026 workers were offered reinstatement, and 3294 accepted).

112 See Elvis C. Stephens \& Warren Chaney, A Study of the Reinstatement Remedy under the National Labor Relations Act, 25 LAB. L.J. 31, 40 (1974). 
hostile environment. The other and more pervasive reason for refusing reinstatement is fear of employer retaliation. The employee's perception is that returning to the old job will not work out and the employer will find or manufacture some nondiscriminatory reason for dismissal or will make life on the job intolerable. ${ }^{113}$

An award of back pay, though it replaces lost earnings does not fully compensate the employee for economic loss. The discharged employee may be forced to borrow or buy on credit, but interest on lost pay is not granted. Even more devastatingly, she may be unable to meet installment payments on her car, refrigerator, or house and lose them. The employee may also have to move to another city to find work, at considerable cost. None of these economic losses are compensated, nor are damages awarded for emotional injury, though such injury may lead to illness or other tangible injury.

An award of back pay has a limited deterrent effect on the employer because interim earnings of the employee are deductible. Employees have no choice but to seek other work, not only because of the legal rule requiring mitigation of damages, but more compellingly because of their need to support themselves and their families until back pay is actually paid. Once the employee finds other work, there is little incentive for the employer to settle.

The employer's costs of litigation are relatively small compared with court proceedings because discovery, depositions and other pre-trial procedures are replaced by the Board's processes of investigation and conciliatory administrative procedures and the adjournment of hearings in case of surprise. Employer lawyers report that in a discriminatory discharge case the costs prior to an ALJ hearing run from $\$ 2500$ to $\$ 5000$, and the costs through a Board decision vary from $\$ 10,000$ to $\$ 20,000$-less than one fourth the cost of an employment at will case. ${ }^{114}$

In sum, the Board's remedies provide little deterrence of violations. The average back pay award is about $\$ 2700$, with slightly less than a $30 \%$ chance that the employee will in fact be reinstated. ${ }^{115}$ Many employers consider this a small price to pay for

113 See Warren H. Chaney, The Reinstatement Remedy Revisited, 32 LAB. L.J. 357, 359-61 (1981). The fears have roots in reality: almost $87 \%$ of those reinstated leave within a year, $74 \%$ because of unfair treatment or dismissal. See id. at 360 . For a summarization of unfair treatment studies, see West, supra note 31, at 28-30.

114 These estimates have been reported to me in conversations with practitioners.

115 See 55 NLRB ANN. REP., supra note 85, at 143-44. 
eliminating enough union activists, intimidating others, and maintaining a union free environment.

\section{Title VII ${ }^{116}$}

Enforcement of employment rights under Title VII combines procedures through the Equal Employment Opportunity Commission (EEOC) and private litigation. ${ }^{117}$ Employees who are victims of discrimination must begin by proceeding under state or local law, if it provides relief, for at least sixty days or until the proceedings are terminated. ${ }^{118}$ If the charge is first filed with the EEOC, the Commission refers it to the state or local agency for at least sixty days for the required proceedings. ${ }^{119}$

At the end of the deferral period, if there is one, the EEOC serves notice of the charge on the employer and then investigates the charge. After investigation, the Commission determines whether there is reasonable cause to believe the charge is true. If the Commission finds reasonable cause, it must attempt to eliminate the unlawful practice by the informal methods of conference, conciliation, or persuasion. ${ }^{120}$ If conciliation fails, the Commission may bring a civil action in federal district court, with the person aggrieved entitled to intervene in that action. ${ }^{121}$

Enforcement through the Commission is not exclusive. If the Commission dismisses the charges, or fails to bring suit within 180 days from the date the charge was filed or the deferral to state or local proceedings was terminated, the aggrieved person may bring a private suit in the federal district court, with the Commission entitled to intervene. ${ }^{122}$

One critical characteristic is immediately apparent: although employees who claim they are victims of discrimination are required

116 Civil Rights Act of $1964 \$ \$ 701-716$ (codified as amended at 42 U.S.C. $\$ \S 2000$ e to 2000 e-17 (1988)).

117 For a brief description of the EEOC procedure, see generally BARBARA L. SCHLEI \& PAUL GROSSMAN, EMPLOYMENT DISCRIMINATION LAW 933-1185 (2d. ed. 1983; N. Thompson Powers et al. eds., Supp. 1987-1989; David A. Cathcart ed., Five Year Cum. Supp. 1989; \& Supp. 1991).

${ }^{118}$ See Civil Rights Act of $1964 \S 706$ (c) (codified as amended at 42 U.S.C. $\S 2000 \mathrm{e}-5(\mathrm{c})(1988))$.

119 See 42 U.S.C. § 2000e-5(d); see also SCHLEI \& GROSSMAN, supra note 117, at 941.

${ }^{120}$ See $\S 2000 \mathrm{e}-5(\mathrm{~b})$; see also SCHLEI \& GROSSMAN, supra note 117 , at $942-66,984$ 86.

121 See § 2000e-5(f)(1); see also SCHLEI \& GROSSMAN, supra note 117, at 966-67. 1168.

122 See $\$ 2000 \mathrm{e}-5(\mathrm{f})(1)$; see also SCHLEI \& GROSSMAN, supra note 117, at 946-47, 967, 
to initiate proceedings through the Commission, they do not lose control of their claims. If the Commission finds reasonable cause and proceeds to conciliation, no settlements are binding without the consent of the aggrieved employees. ${ }^{123}$ If the Commission brings suit, the employees can intervene. ${ }^{124}$ More importantly, the employees' right to sue is not dependent on the Commission. Even though the Commission finds a lack of reasonable cause, an aggrieved employee can sue. ${ }^{125}$ The employees need not even wait for the Commission proceedings to run their course. After 180 days, they are entitled to a "right-to-sue" letter even if the Commission has not completed its investigation or has not attempted conciliation. ${ }^{126}$

The relative importance of Commission procedures and private suits is indicated by the following data. In 1988, the EEOC received 58,853 charges for processing. ${ }^{127}$ No cause was found in 35,148 cases, 9129 were settled, withdrawn with benefits, or conciliated, and conciliation was unsuccessful in 1512 cases. ${ }^{128}$ In 1989, only 563 suits for employment discrimination were brought in the federal district courts by the federal government, while 7470 were brought by private plaintiffs. ${ }^{129}$

Reliance by individual employees on enforcement through the EEOG offers two advantages. First, investigation and conciliation help eliminate unfounded claims and settle legitimate claims without litigation. Second, this reliance avoids the need to obtain a lawyer to pursue the claim. Reliance on the Commission, however, carries the cost of delay and uncertainty as to aggressive prosecution.

Processing cases through the EEOC is painfully slow. On the average, 280 days are required to investigate a case and make a determination as to reasonable cause and $\mathbf{2 5 5}$ days are consumed in

123 See SCHLEI \& Grossman, supra note 117, at 966 \& n.275.

124 See supra note 121 and accompanying text.

${ }^{125}$ See $\$ 2000 \mathrm{e}-5(\mathbf{f})(1)$.

${ }^{126}$ See id.; see also SCHLEI \& GROSSMAN, supra note 117, at 946-47.

127 1986-1988 EEOC COMBINED ANN. REP. 24 (1989).

$128 \mathrm{See} i d$. These figures include cases under the Age Discrimination in Employment Act and the Equal Pay Act, and cases which included combined charges under those statutes. The figures for cases charging only violations of Title VII were: received for processing, 42,657; no cause found, 24,836; settled, withdrawn with benefits, or conciliated, 6953; unsuccessful conciliations, 818 .

129 See 1989 DIRECTOR ADMIN. OFF. U.S. CTS. ANN. REP. at app. I at 22. In 1989, the General Counsel's office reported 484 substantive suits filed by the EEOC and 114 subpoena actions. See 1989 EEOC OPERATIONS OFF. GEN. COUNS. ANN. REP. 21. 
conciliation efforts to obtain voluntary compliance and settlement. ${ }^{130}$ When conciliation fails, the case is referred to the General Counsel who uses forty or more days to determine whether to recommend to the Commission that suit be brought. ${ }^{131}$ Then, the Commission takes another forty days to decide whether to litigate. ${ }^{132}$ Thus, the average case spans more than 600 days from the filing of a charge until the case is referred to the General Counsel to prepare to bring suit. This is the average processing time; some stages may take twice as long. ${ }^{133}$

The Commission's stated policy is that it will consider for litigation all cases where reasonable cause is found and conciliation has failed. ${ }^{134}$ Unfortunately, this does not assure the victim of discrimination that she will have an energetic advocate, or even an advocate at all. For the fiscal year 1989, the Commission reported 1512 cases where conciliation was unsuccessful, ${ }^{135}$ but only 808 recommendations for litigation were made to the General Counsel by the regional offices. ${ }^{136}$ The General Counsel recommended only 714 cases to the Commission for litigation, ${ }^{137}$ and 484 suits were filed. ${ }^{138}$ In short, the Commission brought suit in less than $30 \%$ of the cases in which reasonable cause was found and conciliation failed.

The inadequacy of enforcement through the EEOC is, in large measure, the result of inadequate funds to handle the caseloads, which limits the EEOC's efforts and causes delays. Although the Commission has repeatedly pointed out to Congress the need for more adequate funding, the money has not been provided. ${ }^{139}$

${ }^{130}$ See EEOC Delays in Processing Age Discrimination Charges: Hearing Before a Subcomm. on Employment and Housing of the House Comm. on Gov't Operations, 100th Cong., 2nd Sess. 37, 40 (1988) [hereinafter EEOC Delays] (statement of Clarence Thomas, Chairman, EEOC).

131 see id.

132 See id.

135 See id.

134 See 19 EEOC ANN. REP. 5 (1984); New EEOC Policy Calls for Litigation in All Cases Where Conciliation Fails, 56 White Collar Rep. (BNA) No. 10, at 304 (Sept. 12, 1984).

135 See 1986-1988 EEOC COMBINED ANN. REP., supra note 127, at 120.

7.

${ }^{136}$ See 1989 EEOC OPERATIONS OFF. GEN. COUNS. ANN. REP., supra note 129, at

137 See id. at 17.

138 See id. at 21.

${ }^{139}$ See EEOC Delays, supra note 130, at 40 (statement of Clarence Thomas, chairman, EEOC). When enforcement of the Age Discrimination Act was transferred from the Department of Labor to the EEOC, the budget proposal contained no 
Because of the Commission's slow rate of processing cases and the uncertainty that the Commission will bring suit, the great majority of victims rely on private suits rather than on the Commission. ${ }^{140}$ If a lawyer determines that the case is worth litigating, he will ask for a "right-to-sue" letter and bring suit, getting to court a year or more before the Commission would have begun preparing to sue, if it decided to sue at all. It is not surprising that more than $90 \%$ of enforcement actions are brought by private plaintiffs. ${ }^{141}$ This does not mean that the Commission's efforts are wasted in these cases, for the plaintiff will be able to obtain the Commission's investigation reports to prepare the case, thus reducing litigation costs. ${ }^{142}$

Whether suit is brought by the Commission or a private party, the procedures and remedies are the same, except that the Commission may, in appropriate cases, obtain a preliminary injunction pending investigation and conciliation efforts. ${ }^{143}$ Remedial powers are broadly stated in the statute. The court may enjoin unlawful employment practices and "order such affirmative action as may be appropriate, which may include, but is not limited to, reinstatement or hiring of employees, with or without back pay ..., or any other equitable relief as the court deems appropriate." 144 In cases of systematic discrimination, the remedies are far-reaching. Courts may not only enjoin future violations, but may also impose affirmative programs to correct the effects of past discrimination. ${ }^{145}$ In individual cases, the remedy has usually been limited to hiring or reinstatement with back pay, with back pay limited to two years prior to filing the charge. ${ }^{146}$ In exceptional

increase for this added burden. See 136 Lab. Rel. Rep. (BNA) 129, 147 (Feb. 11, 1991).

${ }^{140}$ See, e.g., text accompanying note 129.

141 See 1989 Director ADMIN. OFF. U.S. CTS. ANN. REP., supra note 129, at 22.

142 Although sections 706 and 709 of the Civil Rights Act of 1964 prohibit making public any information obtained during the investigation and conciliation proceedings, see 42 U.S.C. $\$ \S 2000 \mathrm{e}-5(\mathrm{~b}), 2000 \mathrm{e}-8$ (e) (1988), the Supreme Court has held that the charging party is not a member of the public within these two sections and can be given access to the contents of the investigative files in his case. See EEOC v. Associated Dry Goods Corp., 449 U.S. 590 (1981). The EEOC must make the investigative file available to a charging party who is contemplating litigation. See id. at 598,603 .

${ }^{143}$ See 42 U.S.C. $\$ 2000 \mathrm{e}-5(f)(2)$.

${ }^{144} I d . \S 2000 \mathrm{e}-5(\mathrm{~g})$.

145 See SCHLEI \& GROSSMAN, supra note 117, at 1395-1417, 197-207 (1983 \& 2d ed. Supp. 1987-1989) (noting that courts may also provide for monetary relief).

${ }^{146}$ See Fred W. Alvarez \& Barbara Lipsky, Remedies for Individual Cases of Unlawful 
cases where reinstatement is not practicable, the court may order "front pay" for prospective wage losses, ${ }^{147}$ a remedy mainly utilized in age discrimination cases. ${ }^{148}$

Prior to the Civil Rights Act of 1991, statutory remedies protected individual employees from continued or repeated violations of their rights and made them whole for lost wages. ${ }^{149}$ Employees were not compensated, however, for emotional and psychological injury, ${ }^{150}$ which may be more substantial than any monetary loss. Although back pay provides a measure of deterrence for employers, ${ }^{151}$ the lack of either emotional distress damages or punitive damages allows racial, religious, and sexual harassment to continue uncompensated and undeterred as long as the employee is not actually terminated. The only deterrent for an employer in harassment situations has been the cost of legal fees if the employer contests the claim. This defect has been substantially ameliorated by the Civil Rights Act of 1991, which provides for limited compensatory and punitive damages in cases of intentional discrimination. ${ }^{152}$

Title VII attempts to make remedies for employment discrimination more effective by providing that the judge shall assign the case for hearing "at the earliest practicable date and to cause the case to be in every way expedited." ${ }^{\text {153 }}$ Even so, the median time between

Employment Discrimination: A Law Enforcement Perspective, 3 LAB. LAW. 199, 209 (1987).

147 See Schlei \& Grossman, supra note 117, at 1434-36 \& 203-04 (1983 \& 2d ed. Supp. 1987-1989).

${ }^{48}$ See Bridget Flanagan, Comment, Front Pay as a Remedy Under the Age Discrimination in Employment Act of 1967, 19 U.S.F. L. REv. 187, 187-88 (1985) (acknowledging awards of front pay in Title VII cases, but questioning the appropriateness of front pay awards under the Age Discrimination in Employment Act); Peter Janovsky, Note, Front Pay: A Necessary Alternative to Reinstatement Under the Age Discrimination in Employment Act, 53 FORDHAM L. REV. 579, 582 (1984) ("[Some] courts . . . have allowed recovery of front pay [under ADEA] on the ground that it is necessary to make a plaintiff whole when reinstatement is not possible.")

149 See 42 U.S.C. \$ 2000e-5(g).

150 See SCHLEI \& GROSSMAN, supra note 117, at 1452 n.153, 1453 n. 161, 207 (1983 \& 2d ed. Supp. 1987-1989) (noting that compensatory and punitive damages are not allowed under ADEA). Compensatory and punitive damages, however, may be awarded in actions under $\S 1981$ or $\S 1983$, which may be joined with a Title VII action. See id.

${ }^{151}$ But see supra notes 77-80 and accompanying text.

152 See Civil Rights Act of 1991, 42 U.S.C.S. $\$ 1981$ (a) (to be codified at 42 U.S.C. $\$ 1981(\mathrm{a})$ ).

15342 U.S.C. § $2000 c-5(f)(5)(1988)$. 
filing and final disposition in a district court is eight months, ${ }^{154}$ and, in $10 \%$ of the cases, it is as long as twenty-eight months. ${ }^{155}$ For cases which go to trial, the median time until final disposition is fourteen months, and for $10 \%$ of the cases it is more than thirtysix months. ${ }^{156}$ In 1989 , over a thousand cases had been pending for more than three years. ${ }^{157}$

One significant aspect of remedies under Title VII is the use of the class action. If the EEOC sues, it need not be certified as class representative under Federal Rule of Civil Procedure 23, and it may seek injunctive relief and back pay for all affected by the challenged practice. ${ }^{158}$ In fact, more than one fourth of the suits brought by the Commission are class actions. ${ }^{159}$ Private suits, however, must comply with Rule 23. ${ }^{160}$ Prior to the Supreme Court decisions in $1977^{161}$ and $1982,{ }^{162}$ the courts were lenient in certifying class actions, based on the belief that, "[a] suit for violation of Title VII is necessarily a class action as the evil sought to be ended is discrimination on the basis of a class characteristic." ${ }^{163}$ Therefore, Title VII cases were appropriate for across the board certification for all types of discrimination, regardless of the type of discrimination suffered by the plaintiff. ${ }^{164}$ The two Supreme Court decisions mandated stricter compliance with the requirements of Rule 23, making resort to class actions more complicated, but still viable. ${ }^{165}$

The class action has two substantial advantages. First, it provides remedies in a single proceeding for a large number of

154 See 1989 DIRECTOR ADMIN. OFF. U.S. CTS. ANN. REP., supra note 129, at 10.

155 See id. at 212.

156 See id. at 233 .

157 See id. at 11.

${ }^{158}$ See General Tel. Co. v. EEOC, 446 U.S. 318, 324 (1980).

${ }^{159}$ See 1989 EEOC OPERATIONS OFF. GEN. COUNS. ANN. REP., supra note 129, at 5.

${ }^{160}$ See SCHLEI \& GRosSMAN, supra note 117, at 1216-70 (noting that unions and civil rights organizations are bound by Rule 23 requirements).

${ }^{161}$ See East Texas Motor Freight Sys., Inc. v. Rodriguez, 431 U.S. 395, 403-06 (1977) (dismissing Title VII class action on account of petitioner's failure to meet both procedural and substantive requirements of Rule 23).

${ }^{162}$ See General Tel. Co. v. Falcon, 457 U.S. 147, 156 (1982) (holding that an individual litigant seeking to initiate a Title VII class action must meet the requirements of Rule 23).

${ }^{163}$ Bowe v. Colgate-Palmolive Co., 416 F.2d 711, 719 (7th Cir. 1969).

164 See Bowe, 416 F.2d at 720.

165 See generally SCHLEI \& GROSSMAN, supra note 117, at 1216-70, 169-79 (1983 \& $2 d$ ed. Supp. 1987-1989) (discussing the application of Federal Rule of Civil Procedure 23 to Title VII class actions). 
individual employees, including those who may not have filed a complaint, or even knew that their rights had been violated. Second, and more importantly, by including a large number of people, a class action helps counteract the formidable power and resources of the employer and makes the litigation financially practicable for both the plaintiff and the lawyer when an individual suit would not be practicable. ${ }^{166}$

From the standpoint of efficacy of remedies, the most important provision of Title VII empowers the court to allow the prevailing plaintiff reasonable attorneys' fees as a part of the costs. ${ }^{167}$ The plaintiff is viewed as a "private attorney[] general"168 and is awarded attorneys' fees as a matter of course in the absence of special circumstances. ${ }^{169}$ Attorneys' fees awards include fees incurred representing the plaintiff before state fair employment agencies and the EEOC. ${ }^{170}$ Furthermore, public interest law firms are entitled to fees calculated at the same rates as private attorneys. ${ }^{171}$ Contingent fee agreements will not limit the statutory fees which the prevailing plaintiff may recover. ${ }^{172}$ The amount of the fee is calculated on the basis of the hours reasonably spent on the litigation multiplied by a reasonable hourly rate for a lawyer of

${ }^{166}$ Cf. David L. Biek, The Scourge of Age Discrimination in the Workplace: Fighting Back with a Liberalized Class Action Vehicle and Notice Provision, 37 CASE W. REs. L. REV. 103, 107 (1986) (noting that the Senate Committee agrees "with the courts that Title VII actions are by their very nature class complaints, and that any restrictions on such actions would greatly undermine the effectiveness of Title VII.") (quoting Final Report of the Senate Labor \& Public Welfare Committee, S. Rep. No. 415, 92d Cong., 1st Sess. 27 (1972)); David Scanga, Comment, Title VII Class Actions: A New Era?, 62 NeB. L. REv. 130, 130-31 (1983) (noting that after the Civil Rights Act of 1964 , most federal courts concluded that Title VII actions were by definition class actions).

167 See 42 U.S.C. $\$ 2000$ e-5(k).

${ }^{168}$ Albemarle Paper Co. v. Moody, 422 U.S. 405, 415 (1975).

169 See New York Gaslight Club, Inc. v. Carey, 447 U.S. 54, 68 (1980). See generally SCHLEI \& GROSSMAN, supra note 117, at 1466-1511, 208-10 (1983 \& 2d ed. Supp. 1987-1989) (discussing plaintiff's power to seek attorneys' fees award).

170 See SCHLEI \& GROSSMAN, supra note 117, at 1473-81.

171 See Shadis v. Beal, 685 F.2d 824, 831-32 (3d Cir. 1982); Minority Employees at NASA v. Frosch, 694 F.2d 846, 847 (D.C. Cir. 1982); SCHLEI \& GROSSMAN, supra note 117, at 1480-81 n.9. But see EEOC v. Steamfitters Local 638, 542 F.2d 579, 593 (2d Cir. 1976) (holding that public interest firms entitled to fee award, but within court's discretion to issue award lower than private law firm rate). See generally Note, Awards of Attorny's Fees to Legal Aid Offices, 87 HARV. L. REV. 411, 415 (1973) (noting statutory basis for attorneys' fees awards to Legal Aid offices).

172 See Sisco v. Alberici Constr. Co., 733 F.2d 55, 56 (8th Cir. 1984) (holding that "a percentage fixed in a contingent-fee contract is not an absolute ceiling on fee awards"); Cooper v. Singer, 719 F.2d 1496, 1501 (10th Cir. 1983). 
equal competence and experience in the community. This "lodestar" figure may be adjusted up or down based on a number of factors. ${ }^{173}$

Without the provision for attorneys' fees, most victims of discrimination would have no recourse except to the state agency, where one is available, and the EEOC, with its wholly inadequate resources. The legal costs of carrying a case to summary judgment, even with the aid of the EEOC's investigative report, ${ }^{174}$ will customarily be $\$ 20,000$, and if the case proceeds to trial, the legal costs will be at least double. ${ }^{175}$ Few individual victims can afford to pay such costs. Contingent fee arrangements provide no solution because recovery is limited to lost wages. Rarely would even a sizeable percentage of this amount be sufficient to compensate an attorney for her time and expense. In many cases, the attorneys' fees awarded in Title VII cases are substantially more than the total recovery of the plaintiff. ${ }^{176}$

173 See Hensley v. Eckerhart, 461 U.S. 424, 429-30 (1983). The Court adjusted the "lodestar" by applying the 12 factors listed in Johnson v. Georgia Highway Express, Inc., $488 \mathrm{~F} .2 \mathrm{~d} 714$ (5th Cir. 1974). The twelve factors are: 1) the time and labor required; 2) the novelty and difficulty of the questions; 3) the skill requisite to perform the legal service properly; 4) the preclusion of employment by the attorney due to acceptance of the case; 5) the customary fee; 6 ) whether the fee is fixed or contingent; 7) time limitations imposed by the client or the circumstances; 8) the amount involved and the results obtained; 9) the experience, reputation, and ability of the attorneys; 10) the "undesirability" of the case; 11) the nature and length of the professional relationship with the client; and 12) awards in similar cases. Id. at 717-19. In a later decision, Blum v. Stenson, 465 U.S. 886 (1984), the Court stated that the lodestar should be adjusted only in exceptional cases because many of the Johnson factors were implicitly included in the hourly rate and number of hours. See id. at 895-96. The trend appears to be toward restrictive readings of all fee-shifting provisions, so as not to allow contingency enhancement. See, e.g., King v. Palmer, 950 F.2d. 771, 782 (D.C. Cir. 1991) (interpreting Pennsylvania v. Delaware Valley Citizens' Council for Clean Air, 483 U.S. 711 (1987), as barring contingency enhancements).

${ }^{174}$ See supra note 142 and accompanying text; see also Janis G. White, Note, The Use of EEOC Investigative Files in Title VII Actions, 61 B.U. L. REv. 1245, 1245 (1981) (discussing inconsistency in case law regarding the appropriate use of EEOC files).

175 These estimations are based on my conversations with attorneys experienced in this practice area.

176 See, e.g., Branch-Hines v. Hebert, 939 F.2d 1311, 1322-23 (5th Cir. 1991) (remanding for modification of the judgment to reflect special damages of $\$ 7000$ while affirming an award of $\$ 10,098$ for attorneys' fees); Dixon v. Sewage $\&$ Water Board, No. 88-3553, 1990 U.S. Dist. LEXIS 9916, at *12-*13 (E.D. La. July 17, 1990) (awarding plaintiff $\$ 18,000$ in compensation for the Title VII claim and $\$ 20,042.20$ in attorneys' fees); Proulx v. Citibank, N.A., 709 F. Supp. 396, 397 (S.D.N.Y. 1989) (awarding plaintiff $\$ 693.55$ in damages and $\$ 6282$ for attorneys' fees). For civil rights cases in general, the Supreme Court has rejected "the proposition that fee awards under $\$ 1988$ should necessarily be proportionate to the amount of damages a civil rights plaintiff actually recovers." City of Riverside v. Rivera, 477 U.S. 561, 574 (1986). In Rivera, respondents were awarded $\$ 33,350$ in compensatory and punitive 
Even so, the provision for attorneys' fees fails to assure an employee whose Title VII rights are violated of finding a lawyer to vindicate those rights. One commentator has noted that plaintiffs' lawyers in equal employment cases "have become an endangered species, in many places already extinct."177

First, attorneys' fees are awarded only if the plaintiff prevails, and in contingent fee cases the lodestar amount will not be increased to compensate for the risk that the case will be lost. In City of Burlington v. Dague, ${ }^{178}$ the Supreme Court refused to approve a $25 \%$ enhancement, declaring that to do so would amount to double-counting because the difficulty in establishing the merits was one of the factors reflected in the lodestar. The Court refused to allow any consideration of the risk factor on the grounds that this would encourage lawyers to take cases with little chance of success in the hopes of receiving a multiple enhancement.

Second, a number of courts, influenced by language of the Supreme Court, have held that where a plaintiff prevails upon part, but not all, of his claims, fees should be awarded only for the time and costs expended on the winning claim. ${ }^{179}$ If a lawyer accepts a case where there are several potential claims, some of which are doubtful, she has a professional obligation to represent the client's interests to the best of her ability and press all substantial claims.

damages and $\$ 245,465.25$ in attorneys' fees. See id. at 561 .

${ }_{177}$ Ray Terry, Eliminating the Plaintiff's Attorney in Equal Employment Litigation: A Shakespearean Tragedy, 5 LAB. LAW. 63, 63 (1989); see also Civil Rights Act of 1990: Hearing Before the Senate Comm. on Labor and Human Resources on S.2104 to Amend the Civil Rights Act of 1964, 101st Cong., 1st Sess. 674 (1990) (statement on behalf of the Mexican American Legal Defense and Educational Fund by Richard E. Larson); J. LeVonne Chambers \& Barry Goldstein, Title VII at Twenty: The Continuing Challenge, 1 LAB. LAW. 235, 257-58 (1985) (criticizing efforts to lower attorneys' fees awards given the prominent role of the private legal sector in initiating Title VII litigation); Steven A. Holmes, Workers Find It Tough Going Filing Lawsuits Over Job Bias, N.Y. TIMES, July 24, 1991, at A1 (documenting private lawyers' desertion of Title VII class action cases).

178112 S. Ct. 2638, 2641 (1992).

179 See Hensley v. Eckerhart, 461 U.S. 424,440 (1983) (holding that "[w] here the plaintiff has failed to prevail on a claim that is distinct in all respects from his successful claims, the hours spent on the unsuccessful claim should be excluded in considering the amount of a reasonable fee"). For examples of reductions in fee awards because of loss on some claims, see Catlett v. Missouri Highway \& Transp. Comm'n, 828 F.2d 1260 (8th Cir. 1987); Uviedo v. Steves Sash \& Door Co., 753 F.2d 369 (5th Cir. 1985); Walje v. City of Winchester, 773 F.2d 729 (6th Cir. 1985); King v. McCord, 707 F.2d 466 (11th Cir. 1983). Where the issues are sufficiently related, however, the court may allow full recovery of attorneys' fees. See Fite v. First Tennessee Prod. Credit Ass'n, 861 F.2d 884 (6th Cir. 1988); Fishman v. Clancy, 763 F.2d 485 (1st Cir. 1985). 
But she then risks not getting paid for the time spent on the doubtful claims, which may be the most difficult and time consuming. The result may be refusal to take the case.

Third, the Supreme Court has held that Title VII does not provide for payment of experts beyond the statutory witness fee of $\$ 30$ a day. ${ }^{180}$ Expert consultation and testimony are often indispensable, particularly in disparate impact cases where the crucial evidence is that provided by labor economists, sociologists, and statisticians. The cost of these studies and testimony may be tens of thousands of dollars. ${ }^{181}$ When these out-of-pocket costs could not be recovered in successful litigation, many meritorious cases could not be brought. The Civil Rights Act of 1991 corrected this defect, however, and explicitly provides for the recovery of experts' fees as a part of attorneys' fees. ${ }^{182}$

Fourth, the lawyer runs a risk of obtaining a settlement for the plaintiff, but no fees for herself. If the employer offers a settlement with no provision for an attorney's fees, the lawyer is ethically obligated to communicate the offer to the plaintiff, and if the plaintiff accepts, the lawyer is bound. ${ }^{183}$ The Supreme Court has held that it is within the trial court's discretion to approve such settlements, barring the lawyer from claiming an additional amount for attorney's fees. ${ }^{184}$ Once scorched by a fee waiver settlement, a lawyer may refuse to take future cases.

Fifth, even though the plaintiff's lawyer thinks she has assurance of ultimately recovering fully adequate attorney's fees and costs, she may not be able to finance the litigation. It can require an investment of hundreds of hours with heavy overhead expenses, with no payment until after three or four years. If there are appeals, the litigation may last ten years. Sole practitioners or small firms, the mainstay of civil rights lawyers, often lack the reserves to

180 See West Virginia Univ. Hosp., Inc. v. Casey, 111 S. Ct. 1138, 1145-46 (1991); Crawford Fitting Co. v. J.T. Gibbons, Inc., 482 U.S. 437, 445 (1987).

181 For example, in Denny v. Westfield State College, 880 F.2d 1465, 1467 (1st. Cir. 1989), the expert witness fees in a sex discrimination case were $\$ 32,763$. The court recognized the need for expert witnesses, but held that in view of Crawford it could not order reimbursement. The back pay awarded was less than $\$ 50,000$. Denny v. Westfield State College, 669 F. Supp. 1146, 1148 (D. Mass. 1987), aff d, 880 F.2d 1465, 1467 (1st. Cir. 1989).

${ }^{182}$ See 42 U.S.C.A. \& 1988(c) (West Supp. 1992).

183 See Evans v. Jeff D., 475 U.S. 717, 755-56 (1986) (Brennan, J., dissenting).

184 See id. at 742-43; see also Freeman v. B \& B Assocs., 790 F.2d 145, 151 (D.C. Cir. 1986) (following the Supreme Court in Evans, holding that a district court not enforce a settlement on the merits, and awarding attorneys' fees). 
carry such cases to conclusion.

Class actions are not as vulnerable to the problem of legal costs as individual suits. Members of the class may each be able to make small contributions to pay some of the expenses incurred, and a contingent fee arrangement may be practicable because the total recovery may be large. However, class actions are much more complex, much more costly in time and expense to litigate, and take longer to reach a final conclusion. Sole practitioners and small firms are often unable to undertake these cases. Lawyers who handle class actions have become "endangered species", as the number of class actions has drastically diminished. In 1976, private lawyers filed 1174 class actions in employment discrimination cases in federal courts, ${ }^{185}$ but by 1989 this had shrunk to forty-six class actions. ${ }^{186}$

The remedies for age discrimination have certain distinctive aspects which are worth noting. The Age Discrimination in Employment $\mathrm{Act}^{187}$ was originally administered by the Department of Labor, and its remedies were based on those under the Fair Labor Standards Act. Although the statute is now administered by the EEOC, the remedial rights remain the same. ${ }^{188}$

First, Rule 23 class actions are not available. Collective suits may be brought, but each plaintiff must individually agree to become a party. ${ }^{189}$ This raises problems of identifying and locating qualified potential plaintiffs and obtaining their consents. ${ }^{190}$ Second, back pay can be awarded only for two years from the bringing of the suit, not two years from the filing of the charge as in Title VII cases. ${ }^{191}$ As a result, delays by the EEOC in investi-

1851977 DiRECTOR ADMIN. OFF. U.S. CTS. ANN. REP. 239.

1861989 DIRECTOR ADMIN. OFF. U.S. CTS. ANN. REP. app. I at 140.

18729 U.S.C. $\$ \S 621-634$ (1988).

${ }^{188}$ See generally Albert F. Kuhl, Remedies Under the Age Discrimination in Employment Act, 2 LAB. LAW. 229 (1986) (focusing on the remedies of backpay, liquidated damages and front pay); J. Hardin Marion, Legal and Equitable Remedies Under the Age Discrimination in Employment Act, 45 MD. L. REV. 298 (1986) (examining the legal and equitable remedies available under the act).

${ }^{189}$ See 29 U.S.C. \$ 216 (b) (1988) ("No employee shall be a party plaintiff to any such action unless he gives his consent in writing to become such a party ....); LaChapelle v. Owens-Illinois, Inc., 513 F.2d 286, 289 (5th Cir. 1975) (holding that only "opt-in" type class actions may be utilized in age discrimination cases).

190 The district court can order the employer to give names and addresses of all similarly situated employees and approve a consent form to be sent to all such employees. See Hoffmann-La Roche Inc. v. Sperling, 493 U.S. 165 (1989).

191 See 29 U.S.C. \$ 255(a) (1988) (providing a two year statute of limitations from the time the cause of action accrued). 
gating and conciliating are at the cost of the plaintiff, and if the plaintiff waits until the EEOC process runs its course she may lose her claim entirely. ${ }^{192}$ Plaintiffs, if they have a lawyer, will ordinarily seek a "right-to-sue" letter at the earliest possible time. Third, the plaintiff is not only entitled to back pay and attorneys' fees, but is entitled to liquidated damages equal to back wages if the violation was "willful."193 The Supreme Court has left unclear what constitutes willfulness, but it is enough if the employer either knew or acted in reckless disregard for whether its conduct violated the Act. ${ }^{194}$ Fourth, front pay is frequently awarded because reinstatement is not practicable. ${ }^{195}$ As a result, the monetary rewards are often very substantial, so contingent fee arrangements make obtaining a lawyer and litigating the case more likely. Even so, the majority of the cases are brought by professional and managerial employees, ${ }^{196}$ suggesting that even liquidated damages and front pay do not provide an adequate remedy for an average worker to find a lawyer to vindicate her rights.

192 When enforcement was transferred to the EEOC, it failed to inform persons filing charges under ADEA of the statute of limitations. In cases where investigation and conciliation procedures continued beyond the two year limitation period, the EEOC erroneously informed the complainants that their cases were still being processed. As a result, the statute ran out on almost 1300 cases. See EEOC Delays, supra note 130, at 27 (statement of Helen McDonald, AARP). A statute was passed to save most of the defaulted claims. See 29 U.S.C. $\$ 626(\mathrm{e})$ ("For the period in which the EEOC is attempting to effect voluntary compliance of this chapter . . . the statute of limitations as provided in section 255 ... shall be tolled, but in no event for a period in excess of one year.").

19329 U.S.C. \$ 626(b).

194 See Trans World Airlines, Inc. v. Thurston, 469 U.S. 111, 129 (1985), in which the Court affirmed the lower court's decision, 713 F.2d 940 (2d Cir. 1983), by applying this test, but left open the effect of employer good faith. See also Kuhl, supra note 188 , at $236-41$.

195 See Davis v. Combustion Eng'g, Inc., 742 F.2d 916, 923 (6th Cir. 1984); Whittlesey v. Union Carbide Corp., 742 F.2d 724, 726 (2d Cir. 1984); O'Donnell v. Georgia Osteopathic Hosp., 748 F.2d 1543, 1550-51 (11th Cir. 1984); Koyen v. Consolidated Edison Co., 560 F. Supp. 1161, 1169 (S.D.N.Y. 1983); Marion, supra note 188, at 331-38 (noting that the weight of authority clearly holds that front pay is an appropriate remedy under the ADEA); Flanagan, supra note 148, at 207-09 (arguing that when the remedy is denied, front pay "may be the only available remedy that will achieve the make whole objective of the [ADEA]"). But see Kolb v. Goldring, Inc., 694 F.2d 869, 874-74 (1st Cir. 1982) (holding that a plaintiff in an age discrimination suit cannot recover damages for future economic loss or front pay even though injury from the discrimination continues).

${ }^{196}$ See Michael Schuster \& Christopher S. Miller, An Empirical Assessment of the Age Discrimination in Employment Act, 38 INDUS. \& LAB. REL. REV. 64, 68 (1984) (noting that $57.4 \%$ of cases are brought by professional or managerial employees). 


\section{REMEDIES FOR UNDERCOMPENSATION: \\ FAIR LABOR STANDARDS ACT (FLSA) ${ }^{197}$ REMEDIES}

Wage-hour cases, unlike job security cases, relate to terms and conditions of on-going employment-minimum wages and overtime premiums. The statutory remedies, like those under Title VII, ${ }^{198}$ are dual-tracked: suits for violations may be brought by either the Secretary of Labor or aggrieved employees. ${ }^{199}$ The remedies, on their face, appear comprehensive. Either the Secretary or the individual may sue for back wages, plus liquidated damages for an additional amount equal to the back wages. ${ }^{200}$ The individual who sues also may recover reasonable attorneys' fees and costs. ${ }^{201}$ The Secretary may, in addition to suing for back wages with liquidated damages, sue to enjoin future violations, ${ }^{202}$ and, in cases of willful violations, may refer the case to the Department of Justice for criminal prosecution with potential penalties of fines up to $\$ 10,000$ and imprisonment for up to six months. ${ }^{203}$

Primary responsibility for enforcement is, in principle, through the Department of Labor. ${ }^{204}$ Enforcement proceedings begin with an investigation by a compliance officer of the Wages and Hours Division. ${ }^{205}$ Seventy-nine percent of all investigations are triggered by complaints filed by employees or "concerned citizens." 206 In initiating the enforcement proceedings, the compliance officer reviews the payroll records which the employer is required by law to keep, ${ }^{207}$ and where the records are inadequate, she interviews employees. ${ }^{208}$ She identifies the type of violations,

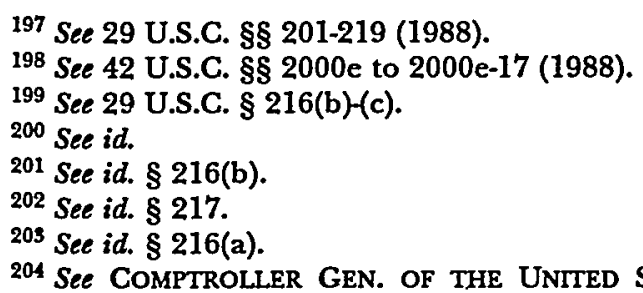

OM OFFICE, No. 60, REPORT TO THE CONGRESS: CHANGES NEEDED TO DETER VIOLATIONS OF THE FAIR LABOR STANDARDS ACT 3 (1981) [hereinafter GAO REPORT I]. For a description of the enforcement procedures, see Stephen G. Wood \& Mary Anne Q. Wood, The Fair Labor Standards Act: Recommendations to Improve Compliance, 1983 UTAH L. REV. 529, 546-48.

205 See Wood \& Wood, supra note 204, at 546.

${ }^{206}$ See 1989 U.S. DEP'T LAB. ANN. REP. 65. In fiscal year 1989, the Wages and Hour Division conducted 74,197 compliance actions, of which 58,449 were initiated by such complaints. See id.

${ }^{207}$ See 29 U.S.C. \$ 211 (c).

${ }^{208}$ See GAO REPORT I, supra note 204, at 12. 
tabulates the amount of back wages due, and attempts to obtain an agreement with the employer to comply with the law in the future and to pay the back wages due. ${ }^{209}$ If the compliance officer is unable to obtain an agreement, the area director attempts to negotiate settlement. ${ }^{210}$ If this fails, the case may be referred to the regional office of the Solicitor of Labor in order to bring a suit. $^{211}$ Further attempts to settle may be made both before and after filing suit. ${ }^{212}$ More than $95 \%$ of all compliance actions are settled before referral to the Solicitor, and suit is filed in almost one-half of the cases referred to the Solicitor. ${ }^{213}$

Enforcement through the Department of Labor has marked weaknesses. First, the agency is woefully lacking in the necessary resources. Compliance officers are able to investigate only $2 \%$ of the covered establishments each year. ${ }^{214}$ Although efforts are concentrated in retail, wholesale and services trades where more than half of the violations occur, ${ }^{215}$ there are not enough compliance officers to make even a random check on these establishments. Because three-fourths of the investigations are initiated by employee complaints, ${ }^{216}$ only one-fourth of the meager resources remain to investigate situations where employees are too uninformed or too afraid to complain. It is estimated that the Department of Labor discovers only one-fifth of all underpayments. ${ }^{217}$ The lack of resources, in addition to limiting investigation of possible statutory violations, weakens enforcement after an investigation has been initiated. Where payroll records are lacking due to employer record

${ }^{209}$ See Wood \& Wood, supra note 204, at 546-47; see also GAO REPORT I, supra note 204, at 4 .

210 See Wood \& Wood, supra note 204, at 547.

211 See id.; see also GAO REPORT I, supra note 204, at 4.

212 See Wood \& Wood, supra note 204, at 548.

213 See id. at 548-50 (stating that of the 2951 FLSA cases referred to the Solicitor in fiscal year 1981 , actions were filed in only 1234 cases, or $42 \%)$. In that year, there was a total of 68,464 FLSA investigations. See 1981 U.S. DEP'T LAB. ANN. REP. 22.

${ }^{214}$ See GAO REPORT I, supra note 204, at 84; 1981 U.S. MINIMUM WAGE STUDY COMM'N, REPORT OF THE MINIMUM WAGE STUDY COMMISSION 156 (1981) (estimating that $8 \%$ are inspected each year) [hereinafter MWSC]. In fact, between 1981 and 1984, the compliance staff was reduced by $15 \%$. See COMPTROLLER GEN. OF THE UNITEd STATES, U.S. GEN. ACCOUNTING OFF., No. 77, REPORT TO THE CHAIRMAN OF THE SUBCOMMITTEE ON LABOR STANDARDS OF THE HOUSE COMMITTEE ON EDUCATION AND LABOR: THE DEPARTMENT OF LABOR'S ENFORCEMENT OF THE FAIR LABOR STANDARDS ACT 5 (1985) [hereinafter GAO REPORT II].

${ }^{215}$ See MWSC, supra note 214 , at 152-54.

216 See supra note 206 and accompanying text.

${ }^{217}$ See MWSC, supra note 214, at 155-56. 
keeping violations, investigators do not have the time to track down all employees and interview them. ${ }^{218}$ Inadequate settlements are accepted because of the costs of collecting adequate proof, ${ }^{219}$ pursuing litigation, and updating investigations prior to finalizing settlement agreements. ${ }^{220}$ Settlement agreements are not followed up to see if violators subsequently comply. ${ }^{221}$ Liquidated damages for willful violations are only available after a jury trial, ${ }^{222}$ and due to a lack of resources and a shortage of available attorneys, such suits are not brought. ${ }^{223}$ Criminal prosecutions are not pressed because the Department of Justice, also lacking adequate resources, assigns these cases a low priority. ${ }^{224}$

Second, record keeping requirements ${ }^{225}$ on which enforcement relies heavily are widely ignored because no civil penalties are assessed for violations, ${ }^{226}$ and criminal prosecutions ${ }^{227}$ generally are not pressed. ${ }^{228}$ At most, a court will issue an injunction ordering compliance with the record keeping requirement, but failure to comply with this order leads to only small monetary penalties. $^{229}$ Employers learn that it pays not to keep records because the lack of records makes proof of violations and the imposition of back wage liability much more difficult. ${ }^{230}$ Thus,

218 See GAO REPORT I, supra note 204, at 12.

219 See id. at 8-9.

220 See id. at 51-55; GAO REPORT II, supra note 214, at 3, app. I at 7.

221 See GAO REPORT I, supra note 204, at 55-57; GAO REPORT II, supra note 214, at 3 , app. I at 7 .

222 See McLaughlin v. Owens Plastering Co., 841 F.2d 299, 301 (9th Cir. 1988).

223 See GAO REPORT I, supra note 204, at 38-41. Other major reasons for not filing such suits include crowded dockets, hesitance in bringing FLSA cases before a jury, the low priority assigned to labor cases in federal district courts, and inadequate evidence caused by record keeping violations. See id. In 1985, the U.S. General Accounting Office identified some improvement in this situation, noting that the Department of Labor was filing more suits for liquidated damages than it had in 1981, and that these suits resulted in the collection of liquidated damages in some cases and increased settlements due to larger initial claims. These results, however, varied from region to region. See GAO REPORT II, supra note 214, at 4-5, app. I at 10-11.

224 See GAO REPORT II, supra note 214, app. I at 3-4.

225 See 29 U.S.C. § 211 (c) (1988).

${ }^{226}$ See id. § 216(b).

227 See id. \$ 216(a).

${ }^{228}$ See GAO REPORT I, supra note 204, at 8 . Nearly one-half of the closed civil cases involved record keeping violations, with $12 \%$ involving "falsified or concealed records." Id. at 8-9.

229 See id. at 8; GAO REPORT II, supra note 214 , app. I at 8.

230 See GAO REPORT I, supra note 204, at 8 . Some employers stop keeping records after the first inspection. See id. at 10, app. I at 25. 
proof often must be obtained through employee testimony, but most employees have incomplete records and unreliable memories, and they may be reluctant to testify, or may have long since left the scene. $^{231}$ Because the evidence is uncertain, cases often are settled for a portion of the wages due or are abandoned entirely. ${ }^{232}$ Record keeping violations are most prevalent in the low wage industries and among small employers, the very situations in which it is most difficult to obtain reliable employees' testimony.

Third, employees' recoveries are wholly inadequate. A primary factor leading to insufficient recovery is the pressure for settlement that results from lack of resources or lack of record keeping. ${ }^{233}$ The total back wages an employer agrees to pay in settlement may be little more than half of the back wages found by the investigator to be owed during the preceding two years. ${ }^{234}$ When the Secretary brings suit it is almost always for an injunction, which allows recovery of wages but does not allow liquidated damages. ${ }^{235}$ This is to avoid the cost and delay of a jury trial, which is required to recover liquidated damages. The statute limits recovery to two years from the time suit is brought, or three years if the violation is willful, but it is normally a year after an investigation begins before a suit is filed. ${ }^{236}$ The result is that if suit is brought, the employee may collect only one year's, or at most two years' underpayment, with no prejudgment interest for the delay in receiving payment. ${ }^{237}$ Employees lose even more because inflation erodes the value of recovery.

Fourth, the enforcement procedures through the Department of Labor do not deter violators. Because there are too few compliance officers, a violator only has one chance in five of getting

231 See id. at 12; GAO REPORT II, supra note 214, app. I at 8-9, 11.

232 See GAO REPORT I, supra note 204, at 8-11; GAO REPORT II, supra note 214, app. I at 9 .

233 See supra note 219 and accompanying text.

234 See MWSC, supra note 214 , at 157 . The GAO found a restoration figure of $60 \%$, which included wages employers agreed or were ordered to pay back to employees. See GAO REPORT I, supra note 204, at 5.

235 See GAO REPORT II, supra note 214 , app. I at 2,5 . Only $4.4 \%$ of compliance cases reach trial where liquidated damages could be assessed. See GAO REPORT I, supra note 204, at 33 .

236 See 29 U.S.C. § 255(a); GAO REPORT II, supra note 214, app. I at 5.

237 See GAO REPORT I, supra note 204, at 50-51, 57-59. Presettlement interest is assessed in only $6 \%$ of the cases, as it is usually negotiated away in reaching a settlement. See id. at 57; GAO REPORT II, supra note 214, app. I at 5. 
caught. $^{238}$ If caught, the violator is assessed only for underpayment for the previous two years. ${ }^{239}$ It can then negotiate for a settlement and, particularly if the record keeping requirement is also violated, the violator might be able to settle for substantially less then the full underpayment. ${ }^{240}$

The employer, however, does not necessarily pay even the full amount of the settlement. If the employer cannot find an employee, she keeps the money, ${ }^{241}$ and there is no systematic follow up to determine if each violator has paid the full amount owed. ${ }^{242}$ If the case is not settled, but is instead referred to the Solicitor, the employer's liability will be further negotiated downward, or reduced by the amount of time the Solicitor takes to prepare the case before bringing suit, because the statute of limitation runs from the date suit is brought, usually a year or more after the violation is found. It is estimated that less than two-thirds of the assessed underpayment is in fact paid, ${ }^{243}$ and it is paid without interest for the period between the date it was due and the date it is paid. In economic terms, it pays the employer to violate the statute.

In addition, repeat violations are not deterred. The agency has had no pattern or policy of investigating violators to determine whether they have changed their ways, ${ }^{244}$ and repeat offenders do

238 See supra note 217 and accompanying text.

239 See GAO REPORT II, supra note 214, app. I at 5.

240 FLSA compliance officers in 1989 found $\$ 29$ million due 151,000 workers for minimum wage violations and $\$ 131$ million due 338,000 employees for overtime violations. Employers agreed to pay $\$ 21$ million in unpaid minimum wages to 124,000 workers, and $\$ 101$ million in unpaid overtime to 287,000 employees. See 1989 U.S. DEP'T LAB. ANN. REP. 65-66; see also, GAO REPORT II, supra note 214, app. I at 9 (finding a strong correlation between record keeping violations and settlements for less than the amount of estimated back wages).

241 If the Secretary litigates the case under $\$ 217$ and obtains an injunction with an order for back pay, the employer is obligated only to compensate those employees who can be found. See GAO REPORT I, supra note 204, app. I at 2 n.2. If, however, she sues under $\$ 216$ (c) for liquidated damages, the amount due unfound employees is paid into the Treasury. See 29 U.S.C. $\$ 216(c)$. Suits are seldom brought under $\S 216$ (c) because of the delay due to the requirement of trial by jury. See supra note 223 and accompanying text. Settlement, therefore, is commonly based on what might be achieved by a $\$ 217$ action. See 29 U.S.C. $\$ 217$.

242 See GAO REPORT II, supra note 214 , app. I at 7.

243 See id. app. I at 2 . In 1977 , Labor Department investigations found that $\$ 88$ million was assessed for overtime violations, but only $\$ 33$ million was paid to employees. See Ronald G. Ehrenberg \& Paul L. Schumann, Compliance With the Overtime Pay Provisions of The Fair Labor Standards Act, 25 J.L. \& ECON. 159, 165 n.14 (1982).

241 See GAO REPORT II, supra note 214, app. I at 6-7. 
not suffer any additional penalties. ${ }^{245}$ Even when an injunction has been obtained to prohibit future violations, the penalties for contempt are smaller than the costs of compliance, ${ }^{246}$ and the criminal penalties are rarely used. ${ }^{247}$

It is no surprise that more than one out of three violators is a repeat offender. ${ }^{248}$ In the words of the GAO, "chances of discovery are slim, penalties are unlikely and the rewards of withholding employees' back wages can be great." ${ }^{249}$ The one-third repeat offender statistic actually underestimates the problem. Employees who have complained once may be reluctant or unable to complain a second time, for they may have seen their fears of retaliation realized. At best, they may have received little back pay and recognized no improvements in the employer's behavior, and therefore may see the filing of a second complaint as a quixotic gesture.

Individual employees, instead of filing a complaint with the Department of Labor, may sue the employer directly. ${ }^{250}$ Few such suits are brought, and for good reasons. First, many employees do not know that their rights are being violated. Many low wage workers may not know the law, or the underpayment may be disguised by deductions for food, tools, uniforms or other charges. Employers may deny high salaried workers overtime pay to which they are legally entitled by denominating them supervisors or administrative personnel, by not paying them for waiting or on-call time, or by using other devices.

Second, individual employees are reluctant to make claims because they justifiably fear losing their jobs, despite the statutory prohibition on retaliation for filing claims. ${ }^{251}$ Apart from fear of

245 See GAO REPORT I, supra note 204, at 32.

246 See supra note 229 and accompanying text.

247 See supra notes $227-28$ and accompanying text.

248 According to GAO REPORT I, supra note 214 , at $23-24,37 \%$ of all employers found in violation are repeat offenders, many with three or more former violations. The report states that, "many employers repeatedly violated the same sections of the Act, and that others falsified or concealed records." Id. These findings indicate that violations are willful. See also MWSC, supra note 214, at 151-53 (discussing factors contributing to noncompliance with FLSA overtime provisions); Ehrenberg \& Schumann, supra note 243, at 161-180 (utilizing an economic model to demonstrate the costs and benefits of noncompliance and positing that some employers consciously weigh these factors when deciding whether to comply with the FLSA).

249 See GAO REPORT I, supra note 204, at 23.

250 See 29 U.S.C. \$ $216(\mathrm{~b})$.

251 See id. \$ $215(\mathrm{a})(3)$. 
retaliation, employees may be persuaded by their employer that if she is required to pay the minimum wages there will be no jobs, or that insistence on premium pay will lead to reduction of hours and take-home pay. Not surprisingly, most of the individual suits are brought by workers who are no longer employed by the defendant employer, and joinder of a back pay claim with a retaliation claim is common. ${ }^{252}$

Third, individual claims are customarily small. The average minimum pay claim is less than $\$ 200$ and the average overtime claim is less than $\$ 400 .^{253}$ This is due, in part to the statute limiting back pay to two years from the date suit is brought, except in cases of willful violation where the limitation is three years. ${ }^{254}$ Although liquidated damages may double this amount, the claims are often not sufficiently large to lead an employee to bring suit, particularly where there is fear of retaliation.

Violations of the statute seldom involve only a single individual. Rather, they constitute practices which apply generally to a group or category of employees. The statute, however, does not allow the ordinary class action, but only a representative action. ${ }^{255}$ Similarly situated employees may be joined as parties plaintiff, but each plaintiff must consent in a writing filed in court. ${ }^{256}$ This requirement makes bringing suit more burdensome, particularly in minimum wage cases, because the employees are often transient or

252 See, e.g., Townley v. Floyd \& Beasley Transfer, No. 88-AR-0907-S, 1989 WL 205342 (N.D. Ala. Dec. 8, 1989) (plaintiff no longer employed by defendant); ReyesGarcia v. New Garden Farms, Inc., No. CIV. A. 88-1629, 1989 WL 16288, at *1 (E.D. Pa. Feb. 24, 1989) (plaintiffs claimed defendants failed to timely pay wages and took retaliatory action).

253 This estimate is based on personal experience and conversations with practitioners. See also supra note 240 and accompanying text. The cases in which representative suits for a number of individuals are brought are, of course, much larger. Some may be substantial, especially suits by a group of employees for overtime. See, e.g., McKenzie v. City of Ottawa, No. CIV. A. 87-2153-0, 1989 WL 45392 , at $* 2$ (D. Kan. Apr. 24,1989$)(\$ 53,581$ for five firefighters and four dispatchers); Brusstar v. SEPTA, No. CIV. A. 85-3773, 1988 WL 137319, at *1-*2 (E.D. Pa. Dec. 21, 1988) ( $\$ 526,330$ for 200 bus drivers).

254 See 29 U.S.C. \$ 255(a). A violation is "willful" if the employer "knew or showed reckless disregard for the matter of whether its conduct was prohibited by the FLSA." McLaughlin v. Richland Shoe Co., 486 U.S. 128, 130 (1988). The behavior must be "conduct that is ... not merely negligen[t]." Id. at 133.

255 See 29 U.S.C. $\$ 216(\mathrm{~b})$.

256 See G.W. Foster, Jr., Jurisdiction, Rights, and Remedies For Group Wrongs Under the Fair Labor Standards Act: Special Federal Questions, 1975 WIS. L. REV. 295, 327; Thomas Ashby, Note, Notice to Class Members Under the Fair Labor Standards Act Representative Action Provision, 17 U. MICH. J.L. REF. 25, 25 (1989-1984). 
change jobs often, making it difficult to locate many of them. The consent procedure also discourages participation for it requires each plaintiff to identify herself in the face of fear of retaliation.

Individual or group suits have two advantages over the procedures of the Wage-Hour Division. First, liquidated damages are regularly claimed and recovered, ${ }^{257}$ in stark contrast to cases enforced by the Wage-Hour Division. ${ }^{258}$

Second, a prevailing plaintiff is entitled to reasonable attorneys' fees and costs, ${ }^{259}$ and these can be substantial. Moreover, the size of the plaintiff's claim does not limit the attorneys' fees allowed. Hourly rates of $\$ 100$ to $\$ 300$ an hour are allowed, depending on lawyers' rates in the area and the individual lawyer's billing rates. ${ }^{260}$ A survey of reported cases for two years shows attorneys' fees and costs running up to $\$ 60,000,{ }^{261}$ and in a large majority of cases the legal costs were substantially more than the back wages. This is particularly true in the minimum wage cases. For example, in one case the back wages were $\$ 4725$, while the attorney's fees and costs were $\$ 15,578 .^{262}$ In another case the back wages with liquidated damages were $\$ 2288$, and the attorney's fees and costs were $\$ 7437 . .^{263} \mathrm{~A}$ marked characteristic of these cases is that few were individual suits; most were brought by groups of employees ranging from four to two hundred individuals. ${ }^{264}$ In many of the situations, however, it would appear that there were others similarly situated who were not made parties to the suit. ${ }^{265}$

${ }^{257}$ See, e.g., Townley v. Floyd \& Beasley Transfer, No. 88-AR-0907-S, 1989 WL 205342 , at *4 (N.D. Ala. Dec. 8, 1989) (awarding plaintiff statutorily required amount of liquidated damages); Brusstar, 1988 WL 137819, at *2 (awarding plaintiffs $\$ 263,165$ in liquidated damages).

${ }^{258}$ See GAO REPORT I, supra note 204, at iv-v; GAO REPORT II, supra note 214, at $4-5$, app. I at $9,14-15$.

259 See 29 U.S.C. $\$ 216(\mathrm{~b})$.

${ }^{260}$ See, e.g., Reyes-Garcia v. New Garden Farms, Inc., No. GIV. A. 88-1629, 1989 WL 16288, at *1-*2 (E.D. Pa. Feb. 24, 1989) (determining value of attorney's time from her nor mal billing rate and legal reputation); Fields v. Luther, No. JH-84-1875, 1988 WL 121791, at *3 (D. Md. July 12, 1988) (noting that billing rates for lawyers in Baltimore and Washington, D.C. range from $\$ 110$ to $\$ 300$ per hour).

${ }^{261}$ See, e.g., McKenzie v. City of Ottawa, No. CIV. A. 87-2153-0, 1989 WL 45392 at *4 (D. Kan. Apr. 24, 1989) ( $\$ 58,637$ attorney's fees); Brusstar v. SEPTA, 1988 WL 137319 , at *9 $(\$ 59,216$ attorney's fees and costs).

262 See Colunga v. Young, 722 F. Supp. 1479, 1487-88 (W.D. Mich. 1989).

${ }^{263}$ See Fields, 1988 WL 121791, at *1, *3. In one overtime case, the wages owed were $\$ 311$ and the attorney fees $\$ 5977$. See Gary v. Health Care Servs., Inc., 744 F. Supp. 277, 278 (M.D. Ga. 1990).

${ }^{264}$ See, e.g., Brusstar, 1988 WL 137319, at *1 (action by more than 200 SEPTA employees).

${ }^{265}$ See, e.g., Fields, 1988 WL 121791, at *4 (citing difficulties of migrant farm 
From this limited survey of cases it would seem that when suits are brought, the employees obtain a substantial remedy, and the award of attorneys' fees and costs makes bringing suits possible, even though the wages recovered are not large. Even so, minimum wage cases, as contrasted with overtime cases, seem to be brought predominately by legal aid and public interest group lawyers. Under City of Burlington v. Dague, ${ }^{266}$ courts cannot enhance the lodestar amount because of the risk of uncertain outcome, and this tends to discourage other lawyers from taking such cases. The provision for legal costs in wage-hour cases have all of the shortcomings discussed in the Title VII cases, except that the cases generally do not require as large an investment of time and expenses.

It might seem that individual suits would be a substantial deterrent to violations. With liquidated damages and attorneys' fees and costs, the total liability may be three to twenty times the underpayment. ${ }^{267}$ Add to this the employer's costs in defending a suit, and the exposure should be a strong deterrent. Individual suits, however, do not in fact provide an adequate remedy or a substantial deterrence. In 1989, the Department of Labor found 74,197 violations, and these constituted only about one-fifth of all violations. ${ }^{268}$ In that year there were only 732 private suits brought for violating the Fair Labor Standards Act. ${ }^{269}$ These suits represent only $1 \%$ of the violations found by the Department of Labor, and only $.2 \%$ of all violations. In practical terms, individual suits border on irrelevancy.

It is not clear why there are so few individual suits, but certainly major contributing causes are the employees' lack of knowledge of their rights and how to enforce them, and their reluctance to make claims for fear of losing their jobs.

It is quite clear, however, that the combination of enforcement through the Department of Labor and individual suits is ineffective to protect workers. Although only a small proportion of employment is in the minimum wage area, in $1979,5 \%$ of all covered establishments were in violation of the minimum wage. ${ }^{270}$ Twelve-point-four percent of all wage and salary employees were

workers in initiating actions due to their itinerant nature and language barriers).

266112 S. Ct. 2638, 2641 (1992).

267 The underpayment is usually for three years because the violations are willful and there is no delay in bringing the suit, as there is when the Solicitor of Labor sues. 268 See 1989 U.S. DEP'T LAB. ANN. REP. 65; supra note 240 and accompanying text. ${ }^{269}$ See 1989 DIRECTOR ADMIN. OFF. U.S. CTS. ANN. REP. app. I at 178.

270 See MWSC, supra note 214, at 161. 
receiving the minimum wage or less. Of these, half were earning less than the minimum wage. ${ }^{271}$ Violations of the overtime provisions were even more prevalent, with $21 \%$ of all covered establishments failing to pay overtime premiums. ${ }^{272}$

\section{REMEdies For VIOLATIONS OF PHYSICAL INTEGRITY}

\section{A. Occupational Safety and Health Act Remedies}

The declared purpose of the Occupational Safety and Health (OSH) $\mathrm{Act}^{273}$ is "to assure so far as possible every working man and woman in the Nation safe and healthful working conditions." ${ }^{274}$ The Act imposes on employers a general duty to "furnish to each of his employees employment and a place of employment which are free from recognized hazards that are causing or likely to cause death or serious physical harm to his employees" and to "comply with occupational safety and health standards promulgated under this chapter. ${ }^{275}$ Employees, however, have no independent statutory remedies for violations or for injuries resulting from violations. Employees are totally dependent on the Occupational Safety and Health Administration (OSHA) for protection.

Enforcement, which is the responsibility of the Department of Labor, begins with inspection of the workplace by an OSHA compliance officer. ${ }^{276}$ After an inspection, which may include examination of injury and illness records and a "walk around" of the plant, the compliance officer discusses with the employer any conditions that she considers violate safety and health standards. The compliance officer then reports the violations to the OSHA area director who discusses the report with the employer; the area director may then issue a citation, propose a fine, and require abatement of the violation within a stated time. ${ }^{277}$ If the employ-

271 See id. at 8.

272 See id. at 161 . Another study of noncompliance with the overtime provisions found that approximately $10 \%$ of covered workers who worked overtime failed to receive the statutory premium. Ehrenberg \& Schumann, supra note 243, at 163.

27329 U.S.C $\$ \$ 651-678$ (1988).

274 Id. $\$ 652(\mathrm{~b})$.

${ }^{275} I d . \S \S 654(\mathrm{a})(1)-(2)$.

276 For a detailed description of the inspection procedure, see generally OSHA Field OPERATIONS MANUAL, 3 Empl. Safety \& Health Guide (CCH) II 7964.100-.800 (July 12, 1990) [hereinafter OSHA FIELD OPERATIONS MANUAL].

277 If the inspector finds conditions that could reasonably be expected to cause death or serious bodily harm before normal enforcement procedure could eliminate them, he may request the Secretary of Labor to seek a restraining order in a United 
er contests the citation, the case is heard by an ALJ. Her decision is binding unless it is appealed and one of the members of the Occupational Safety and Health Review Commission (OSHRC) calls for a "discretionary review." If review is called for, the case will be considered by the full Commission. The Commission's decision or a refusal by the Commission to grant discretionary review may be appealed to the Court of Appeals by any party to the proceedings. 278

Employees whose rights to a safe and healthful workplace are at stake have only a limited role in the enforcement process. An individual employee or "representative of employees" may file a formal (i.e., in writing and signed) complaint with the area director, ${ }^{279}$ thus triggering an inspection. ${ }^{280}$ But an informal complaint, such as one made by telephone, will not result in an inspection unless it alleges imminent danger which could cause death or serious physical harm. ${ }^{281}$ The only action taken on an informal complaint is sending a letter to the employer notifying it of the complaint and advising it to take corrective action. Although employees may trigger inspections by filing complaints, they face the risk of retaliation by the employer, for the statutory guarantee of anonymity may not give full insurance. ${ }^{282}$ Section 11 (c) of the Act prohibits discrimination for filing a complaint, but as will be shown later, this in practice gives employees less than adequate

States district court. See 29 U.S.C. $\$ 662$.

278 See id. \$ 661(j); OccupaTIONAL SAFETY AND HEALTH LAW 478 (Stephen A. Bokat et al. eds., 1988).

279 See 29 U.S.C. \$ 657(f)(1).

280 An inspection will be triggered only if OSHA finds reasonable grounds to believe that there is a violation. See id.

${ }^{281}$ In its early years, OSHA inspected only in response to formal written complaints. In 1975, OSHA changed its policy and conducted inspections in response to all complaints, including those made by telephone and anonymously. Inspections in response to formal complaints were "wall to wall"; but inspections in informal complaints cases were limited to those areas involved in the complaint. In 1979 this policy was reviewed by the General Accounting Office which concluded that a large proportion of complaint inspections did not involve serious risks. As a result, in 1980 OSHA changed its policy to inspecting all formal complaints, but only those informal complaints which alleged imminent danger of "extremely dangerous working conditions." Robert S. Smith, Greasing the Squeaky Wheel: The Relative Productivity of OSHA Complaint Inspections, 40 INDUS. \& LAB. REL. REV. 85, 47 (1986). Subsequent research indicates that during the period from 1977 to 1980 complaint inspections in fact produced as many serious violations as did general scheduled inspections and that inspecting only formal complaints did not increase the productivity of inspections. See id.

282 See 29 U.S.C. § 660(c). 
assurance. ${ }^{283}$ Twenty percent of inspections are triggered by employee complaints, ${ }^{284}$ but a substantial portion of these are filed by unions or in workplaces where the collective agreement protects employees from discipline without just cause. ${ }^{285}$

When an inspection is made, whether as the result of an employee complaint or not, an "employee representative" is entitled to accompany the compliance officer in his walk around the plant and participate in the informal conference with the employer at the end of the inspection. ${ }^{286}$

In the absence of a recognized union, however, there is no established procedure for selecting an employee representative, and an individual who has filed a complaint has no right to participate in the inspection her complaint has triggered. The result is that in the great majority of inspections there is no employee representative to accompany the compliance officer. ${ }^{287}$ Employee participation in non-union workplaces is limited to random discussions with employees by the compliance officer during the inspection. The value of the right of an employee representative to accompany the compliance officer is further diluted by OSHA's revocation in May 1981 of its rule requiring employees to be paid for the time spent during the walk around and in the opening and closing conferences. ${ }^{288}$

283 See generally, James H. Swain, Protecting Individual Employees: Is It Safe to Complain About Safety?, 3 U. BRIDGEPORT L. REV. 59, 83-85 (1988) (stating that while a complaint to OSHA is protected, not all filings with state authorities are protected, and that courts have differed on the protection accorded the various complaints).

284 See OSHA Reports Federal and State Inspection Data for Fïscal 1991, [1991-1992 Transfer Binder] Empl. Safety \& Health Guide (CCH) I 11,152 (Feb. 4, 1992).

285 This situation has been related to me in conversations with practitioners experienced in this area.

${ }^{286}$ See 29 U.S.C. \$ 657(e); see also OSHA FIELD OPERATIONS MANUAL, supra note 276, at II 7964.250, 7964.575 (stating that the compliance officer "shall ensure that employee representatives are afforded the opportunity to participate in all phases of the workplace inspection ${ }^{n}$ and that employee representatives have a right to attend any informal conference with the employer).

287 OSHA justified conducting inspections without an employee representative on the ground that "selection of employee representatives in non-union establishments would entail complex and time-consuming procedures that would seriously delay the conduct of inspections and effective and efficient enforcement of the Act." Revocation of Walkaround Compensation Regulation, 46 Fed. Reg. 28,842, 28,845 (1981). OSHRC defines "authorized employee representative" in its regulations as "a labor organization that has a collective bargaining relationship with the cited employer and that represents affected employees." 29 C.F.R. $\$ 2200.1$ (g) (1991).

${ }^{288}$ See Revocation of Walkaround Compensation Regulation, 46 Fed. Reg. 28,842 (1981). The statute does not by its terms require walkaround pay, see Leone v. Mobil Oil Corp., 523 F.2d 1153, 1159 (D.C. Cir. 1975), but walkaround pay may be required 
After an inspection, if the area director refuses to issue a citation there is no judicial review; the only recourse of a complainant employee or employee representative is an internal appeal to the assistant regional director. ${ }^{289}$ If a citation is issued, an employee or employee representative cannot contest the characterization of the violation as willful, serious or non-serious, the size of the fine, or the adequacy of the abatement ordered, but can only contest and appeal to the Commission on the reasonableness of the time allowed for abatement. ${ }^{290}$

If the employer contests the citation, an employee or employee representative can then become a full party and challenge all aspects of the citation or its withdrawal before the Commission. ${ }^{291}$ They cannot, however, challenge any settlement reached between OSHA and the employer, ${ }^{292}$ and $90 \%$ of the contested citations are settled before reaching the Commission. ${ }^{293}$ Employees or em-

by regulation. In 1977, the Secretary issued an "interpretation" rule requiring walkaround pay, see 42 Fed. Reg. 47,344 (1977), but this was vacated for failure to comply with the Administrative Procedure Act. See Chamber of Commerce of the United States v. OSHA, 636 F.2d 464, 470 (D.C. Cir. 1980). The rule was reissued in the closing days of the Carter Administration, see 45 Fed. Reg. 75,232 (1980), but was revoked within five months by the Reagan Administration. See 46 Fed. Reg. 28,842 (1981).

${ }^{289}$ See 29 C.F.R. § 1903.12(a) (1991). Where there is an alleged imminent danger of death or serious bodily injury, and the Secretary arbitrarily fails to seek an injunction, an employee who is at risk or her representative may seek a writ of mandamus from the U.S. district court. See 29 U.S.C. \$ 662(d) (1988).

290 See 29 U.S.C. $\$ 659$ (c); 29 C.F.R. \$ 1903.17(b) (1991); UAW, Local 588 v. OSHRC, 557 F.2d 607, 609 (7th Cir. 1977) (holding that an employee representative may insist only that OSHRC review the reasonableness of the period of time fixed in citation for abatement of violation); cf. Cuyahoga Valley Ry. v. United Transp. Union, 474 U.S. 3, 6 (1985) (holding that the Secretary of Labor has unreviewable discretion to withdraw citation charging employer with violation of OSH Act); Jonathon J. Nadler, Note, Employee Participation in Occupational Safety and Health Review Commission Proceedings, 85 CoLUM. L. REV. 1317, 1319 (1985) (stating that employees may begin a contest only by alleging that the period of time fixed in the citation for abatement of the violation is unreasonable).

291 See Oil, Chem. \& Atomic Workers Int'l Union v. OSHRC, 671 F.2d 643, 646 (D.C. Cir. 1982) (holding that a labor union representing affected employees can appeal an OSHRC decision when the union has participated as a party in the proceedings). In 1988, employers contested $6.8 \%$ of citations. See U.S. DEP'T OF LABOR \& OSHA, REPORT OF THE PRESIDENT TO THE CONGRESS ON OCCUPATIONAL SAFETY AND HEALTH FOR FISCAL YEAR 1988, at V-14 (1990) [hereinafter 1988 PRESIDENT'S REPORT]. This is an increase from 2.7\% in 1985. See id.

292 See Cuyahoga Valley $R y ., 474$ U.S. at 7 ("A necessary adjunct of [the Secretary's] power is the authority to withdraw a citation and enter into settlement discussions with the employer."). Employees or employee representatives may, however, challenge a settlement as to the reasonableness of the abatement date. See 29 U.S.C. § 659(c); Donovan v. OSHRC, 713 F.2d 918 (2d Cir. 1983).

293 See Mark A. Rothstein, Occupational SAFETY AND HEAlth LAW $\$ 366$ 
ployee representatives are entitled only to be notified of the negotiations and to present their views, nothing more. ${ }^{294}$

Because enforcement is so completely controlled by the agency, employees' rights and remedies depend heavily on the effectiveness of OSHA's enforcement-its resources, its aggressiveness in correcting violations, and its willingness to impose penalties to deter willful and persistent violations. OSHA's protection of employees' rights is flawed both in structure and administration. First, the statute provides no remedy for employees victimized by violations, even if the violations are willful or repeated. Meat-processing employees with paralyzed arms and mutilated hands, textile workers disabled by white lung, and the families of construction workers buried in collapsed buildings obtain no recovery under the statute. OSHA may assess large fines, but the money goes to the government and not to the victims. ${ }^{295}$ Their only recovery may be under wholly inadequate state workers' compensation statutes, most of which take no account of the employer's safety and health violations. ${ }^{296}$

Second, inspections are too few and far between to discover more than a small fraction of violations. In 1988, OSHA had only 1181 compliance officers ${ }^{297}$ to inspect $4,500,000$ firms employing

\section{(1990).}

294 See Boise Cascade Corp., 4 Empl. Safety \& Health Guide (CCH) I 29,222 (Feb. 19,1991 ) (holding that union had been afforded a sufficient opportunity for input in settlement negotiations where the Secretary had informed the union on several occasions of the negotiations and had given the union opportunities to discuss its concerns); see also National Steel \& Ship Bldg. Co., 1987-1990 O.S.H. Dec. (CCH) I 29,127 (holding that employees or their representatives must have an opportunity to provide input before the employer reaches a finalized settlement agreement with the Commission).

${ }^{295}$ See 29 U.S.C. $\$ 666(l)$.

${ }^{296}$ In some states, workers' compensation awards may be increased by a certain percentage if the employer's violation of safety laws caused the injury. See CAL. LAB. CODE $§ 4553$ (West 1989) (50\% increase); MASS. ANN. LAWS ch. 152, § 28 (Law. Coop. 1989) (100\% increase); OHIO CONST. art. II, § 35 (50\% increase); WIS. STAT. ANN. $\$ 102.57$ (West 1991) (15\% increase to a maximum of $\$ 10,000$ ). If the injury results from a statutory violation of another employer, the employee will have a third party action and the statutory violation may be per se negligence in some states. See ROTHSTEIN supra note $293, \$ 513$.

297 See NATIONAL SAFE WORKPLACE INST., FAILED OPPORTUNITIES: THE DECLINE OF JOB SAFETY IN THE 1980's 11 (1988) [hereinafter FAILED OPPORTUNITIES]. 
65 million workers, ${ }^{298}$ and made less than 59,000 inspections, ${ }^{299}$ thus covering less than three million employees. If the sparse resources were spread evenly, each establishment would be inspected about every seventy-five years. OSHA, however, targets for inspections those industries which have the highest accident rates. As a result, $83 \%$ of the inspections are in construction and manufacturing. ${ }^{300}$ Even in the target industries, however, inspections are made only every eight to ten years, ${ }^{301}$ which is too seldom to deter violations. When inspections are made, $69 \%$ of construction workplaces and $73 \%$ of manufacturing workplaces have violations. ${ }^{302}$

Because construction and manufacturing industries were targeted only about 10,000 inspections were made in all other industries, ${ }^{303}$ which together employ $75 \%$ of the workforce. ${ }^{304}$ The result is that workplaces in other industries are almost never inspected unless an employee files a formal complaint. Employees outside construction and manufacturing are therefore effectively without protection because most employees are fearful of retaliation if they file complaints before the danger is realized, and inspections are otherwise triggered only in when an employee is killed or there is a catastrophe. ${ }^{305}$

Third, the civil penalties imposed are too small to provide substantial deterrence. In 1980 , the average penalty proposed for non-serious violations was $\$ 2.04$, and for serious violations, those

298 See Oversight of the Occupational Safety and Health Administration, 1988: Hearings Before the Senate Comm. on Labor and Human Resources, 100th Cong., 2d Sess. 7 (1988) (testimony of Lynn Williams, Chairman, AFL-CIO Standing Committee on Safety and Occupational Health).

299 See 1988 PRESIDENT'S REPORT, supra note 291, at V-14.

300 See id. at V-13 to V-14. Inspections made because of formal complaints by employees are not limited to targeted industries, and inspections are made in all cases of fatalities. See id.

301 See id.; see also DON LOFGREN, DANGEROUS PREMISES: AN INSIDER's VIEW OF OSHA ENFORCEMENT 215 (1989) (estimating targeted industry inspection rate at once every five to six years for those requiring "special emphasis" and less frequently for other establishments).

302 See 1988 PRESIDENT'S REPORT, supra note 291, at V-13.

${ }^{303}$ See id.

304 See supra note 298 and accompanying text.

${ }^{305}$ In a five year period only $2 \%$ of the over 300,000 restaurant and apparel establishments were inspected, an average of once every 250 years. U.S. Gov'T ACCOUNTING OFF., HRD-130 BR, "SWEATSHOPS" IN THE UNITED STATES: OPINIONS ON THEIR EXTENT AND POSSIBLE ENFORCEMENT OPTIONS 45-46 (1988) [hereinafter 'SWEATSHOPS' IN THE U.S.]. Forty percent of the apparel establishments and $60 \%$ of the restaurants inspected had violations. See id. at 46-47. 
where there is a substantial probability that death or serious physical harm could result was $\$ 303.47 .{ }^{306}$ Penalties proposed for willful or repeated violations averaged $\$ 5272.75$ in $1988^{307}$ The amount actually paid, however, is generally about one-third the proposed amount because more than $90 \%$ of all citations are settled by negotiation with a reduction or elimination of the fine, ${ }^{308}$ usually in exchange for the employer's agreement to correct the unsafe condition. ${ }^{309}$ Settlements are driven by two principle considerations. The Solicitor's office lacks the resources to prosecute all the contested citations, ${ }^{310}$ and the agency is primarily interested in protecting employees in the future rather than punishing employers for past violations. The purpose of the statute, it is said, is corrective and not punitive.

Appealing as this policy may be, the lack of substantial penalties provides little incentive for employers to take corrective action until

${ }^{306}$ See infra note 345 and accompanying text.

307 See 'SWEATSHOPS' IN THE U.S., supra note 305, at 47.

308 Between March, 1986 and February, 1990, in a 45-case sample of "egregious" violations, fines were reduced in $72 \%$ of the settled cases (which constituted $28 \%$ of the sample), and in 95\% of the litigated cases. See OFFICE OF INSPECTOR GEN., U.S. DEP'T OF LABOR, REP. NO. 05-92-008-10-001, REVIEW OF HOW OSHA SETTLED AND FOLLOWED UP ON ITS EGREGIOUS CASES 7, 15 (1992) [hereinafter REPORT OF INSPECTOR GEN.]. Of more than $\$ 36$ million in proposed penalties for the settled cases, OSHA negotiated to receive $\$ 10.3$ million and actually collected $\$ 9.9$ million; in litigated cases, OSHA received $\$ 21,900$ of the $\$ 121,500$ due, reduced by courts from more than $\$ 3$ million in penalties proposed. Id. See also FAILED OPPORTUNITIES, supra note 297, at 20-21 (listing examples of reductions of large proposed fines). A study of the $\mathbf{5 0}$ largest corporations showed that the average fine collected per citation was less than $\$ 250$. JAMES DONAHUE, WORKERS AT RISK: A SURVEY OF OSHA'S ENFORCEMENT RECORD AGAINST THE 50 LARGEST U.S. CORPORATIONS 4 (1991).

${ }^{309}$ USX was assessed fines totalling $\$ 7,300,000$ for 1700 violations at its Fairless Hills and Clairton plants. These were settled for $\$ 3,300,000$ with the company agreeing to abate the hazards cited and to implement corporate-wide programs on a number of other safety and health hazards. USX Corp. Accepts Fine of $\$ 3.3$ Million to End OSHA Case, WALL ST. J., Dec. 21, 1990, at A70. IBP was assessed fines totalling $\$ 5,700,000$ for 1038 continued willful underreporting violations and more than 625 other egregious wilful violations. These were settled for $\$ 975,000$, with an agreement by the company that it would institute substantial corrective and preventative measures. See Marianne Lavelle, When Fines Collapse: Critics Target OSHA Settlements, NAT'L L.J., Dec. 4, 1989, at 1. John Morrell and Co. had 800 out of 2000 employees injured in one year at a single plant, and a $\$ 5,000,000$ fine was reduced to $\$ 437,000$. See Thomas E. Quigley, Employee Involvement in the OSHA Settlement Process, 1990 DET. C.L. REV. 579, 590. For a justification of this process of negotiating settlements, see REPORT OF INSPECTOR GEN., supra note 308, at 11-16. For a biting criticism of this process, see LOFGREN, stupra note 301, at 222-25.

${ }^{310}$ See REPORT OF INSPECTOR GEN., supra note 308 , at 4,61 . 
after they are cited for violations. ${ }^{311}$ Eliminating unsafe and unhealthy conditions is often very costly and may require large capital investments in ventilation systems, safety devices, and redesigned equipment. Eliminating unsafe conditions may also impose increased operating costs in shoring trenches, maintaining guard rails and safety nets, and identifying and substituting nontoxic replacements for the toxic substances being used. With the prospect of inspections at eight or ten year intervals, the savings from noncompliance may well be far greater than the fines, even before they are negotiated downward. Fines, even large ones, do little to deter serious willful or repeated violations.

Fourth, abatement orders and employer agreements to abate do not assure employees a safe and healthful workplace. Follow-up inspections to determine whether the hazards continue are conducted in less than $10 \%$ of the cases, ${ }^{312}$ although in $32 \%$ of the follow-up inspections the employer has failed to abate. ${ }^{313}$ In $90 \%$ of the cases where a violation has been found, a statement by the employer, even over the telephone, ${ }^{314}$ that the hazard has been abated is accepted as sufficient. ${ }^{315}$ Again, this is justified by the lack of resources to make the follow-up inspections. If there is a follow-up and the employer's failure to abate is discovered, enforcement procedures are seldom sought in the courts. ${ }^{316}$

311 The standard for determining the size of the penalties do not require consideration of the employer's economic benefit from the violations. See U.S. GEN. ACCOUNTING OFF., GAO/HRD-92-48, OCCUPATIONAL SAFETY AND HEALTH: PENAlties for Violations ARE WELl Below MAXIMUM Allowable PENALTIES 6 (1992) (noting that the Environmental Protection Agency policy requires that "penalty amounts be at least as great as the economic benefit . . . an employer receives from not complying with the law").

312 See 1988 PRESIDENT'S REPORT, supra note 291, at V-14. In 1988, 58,354 employers were inspected, with approximately $40 \%$ found in compliance, meaning that approximately 35,000 employers were found in violation, but there were only 3399 follow up inspections. See id.

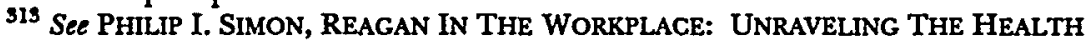
AND SAFETY NET 66 (1983). A GAO Report in 1991 found that in at least $24 \%$ of follow-up inspections, cited hazards had not been corrected. See GAO Report on Adequacy of OSHA Abatement Confirmation Policies, [1991-1992 Transfer Binder] Empl. Safety \& Health Guide (CCH) I 10,927 June 11, 1991) (stating that GAO had "recommended that OSHA promulgate a regulation requiring employers to submit detailed evidence of what corrective actions have been taken to abate hazards").

314 See REPORT OF INSPECTOR GEN., supra note 308, at 25 (noting that OSHA has at times received confirmation of abatements "by telephone conversations with employers or third parties or, in one case, not at all").

315 See id. at 25.

${ }^{316} \mathrm{See}$ id. at 20 . One of the consequences is a delay in enforcement. In one instance, OSHA waited 33 months beyond the waiting period to seek a decree, leaving 
Instead, OSHA issues new citations and seeks new settlements. ${ }^{317}$ In such abatement violation cases, the average penalty is less than $\$ 1029,{ }^{318}$ not enough to provide an incentive to comply where abatement is costly. Even though the employer abates the cited hazard, this gives no assurance that it will not later repeat the violation or commit other violations, which might be discovered at the next inspection five years later. ${ }^{319}$

The limited effectiveness of enforcement is less a product of the size of the fines than of the lack of inspection. Large fines are possible under the statute. Although the maximum penalty for a non-serious or serious violation has been $\$ 1000$ and for a willful and repeated violation $\$ 10,000,320$ where a number of employees are exposed to the same hazard, the exposure of each employee may be treated as a separate violation. ${ }^{321}$ Thus, a single dangerous

employees exposed to asbestos for almost three years. See id. at 21 .

${ }_{317}$ See id. at 20-21 (noting that rather than enforcing a settlement agreement with Ford Motor Company, OSHA issued citations and entered new negotiations, though the old agreement had not been honored).

${ }^{318}$ See 1988 PRESIDENT'S REPORT, supra note 291, at V-14.

${ }^{319}$ In 1988 Zinc Corporation of America agreed to abate lead standard violations and pay $\$ 614,000$. A follow-up inspection found ten failures to abate, five willful and 14 serious violations. A \$208,500 penalty was proposed. See Empl. Safety \& Health Guide (CCH) No. 1046, at 3-4 (May 14, 1991). In 1983 and 1985, ABC Utilities Services, Inc. was cited for five violations of trench safety standards that resulted in a fatal cave-in accident. In 1987, another employee was killed in an unshored trench. OSHA charged the company with 23 willful and three serious violations, proposing penalties of $\$ 231,400$, but agreed to settle for $\$ 55,700$. The company was criminally prosecuted and convicted on two misdemeanor counts. See id. at 3.

32029 U.S.C. $\$ 666$. The statute also provides criminal penalties of up to $\$ 10,000$ and 6 months imprisonment for first-time convictions, and penalties of up to $\$ 20,000$ and one year imprisonment for subsequent convictions. See id. §666(d). Criminal cases are prosecuted by the Department of Justice, which considers such cases a low priority. Between 1970 and 1987 only 41 cases were referred to the Department of Justice; 14 were prosecuted with 10 convictions, but no jail sentences were imposed. See Empl. Safety \& Health Guide (CCH) No. 874, at 1-2 (Feb. 9, 1988). In 1989, OSHA was criticized by the Department of Labor Inspector General for its reluctance to use criminal sanctions. See Empl. Safety \& Health Guide (CCH) No. 965, at 2-3 (Nov. 7, 1989). This criticism was renewed in December 1990, see Empl. Safety \& Health Guide (CCH) No. 1024, at 2 (Dec. 18, 1990) (noting also that the Department of Labor has no system for recording data on criminal investigations), and again in June 1992. See Empl. Safety \& Health Guide (CCH) No. 1104, at 3-4 (June 15, 1992) (noting OSHA's argument that criminalization of reckless violations would potentially affect "[t]ens of thousands of cases each year").

${ }^{321}$ See ROTHSTEIN, supra note $293, \S 252$. In 1986, OSHA instituted a policy of degrouping violations (treating each infraction as a separate violation for penalty purposes) of employers who flagrantly violated safety and health standards in so-called "egregious" violations. In the period of fiscal year 1986 to fiscal year 1990, however, this policy was applied in only 124 cases. The purpose was to deter other employers 
condition such as an unguarded machine or benzine fumes can generate multiple citations with penalties possibly reaching into the millions of dollars. ${ }^{322}$ OSHA, however, generally has not used this device, but has grouped the violations, issuing one citation where it could issue tens or hundreds. ${ }^{323}$ The Omnibus Budget Reconciliation Act of $1990^{324}$ increased the maximum fines for non-serious and serious violations from $\$ 1000$ to $\$ 7000$, and for willful or repeated violations from $\$ 10,000$ to $\$ 70,000 .^{325}$ The motivation behind these increases, however, seemed to have been geared more towards reducing the deficit than reducing the incidence of safety and health violations.

It is doubtful if fines can be practicably made large enough to substantially deter many serious violations so long as employers are inspected only every five or more years. ${ }^{326}$ The fines would need to be extremely large to offset the savings from noncompliance in the intervening years. Employers would inevitably claim, sometimes with justification, that payment of such a fine, in addition to correcting the condition, would drive them out of business. This makes OSHA reluctant to assess large fines and leads it to reduce fines upon the agreement of the employer to use the money to correct the violation. But there is often no follow-up inspection to assure that the employer has lived up to its agreement. Effective enforcement is possible only with frequent inspections and with -systematic follow-up to insure that violations are in fact abated.

This focuses on the crucial structural weakness of OSHA-the

by publicizing the large fines in these cases. See REPORT OF INSPECTOR GEN., supra note 308 , at 7 .

322 In cases of underreporting, a fine may be assessed for each failure to report. For examples, see infra note 335. In other cases where there are "egregious" violations, OSHA will assess separate penalties. Thus, BASF was fined $\$ 1,061,000$, with 104 willful violations for exposing 104 employees to explosion and fire hazards after an explosion and fire killed two employees and injured 17 others. See Empl. Safety \& Health Guide (CCH) No. 1020, at 2-3 (Nov. 20, 1990).

323 See ROTHSTEIN, supra note $293, \S 252$. The practice of degrouping violations in some instances so as to impose larger penalties began in 1985, with the multiple citations for wilful underreporting of accidents. See infra note 335 and accompanying text.

32429 U.S.C. $\$ 666$ (Supp. II 1990).

325 See id. A first-time, willful violation which causes death is punishable as a crime with a maximum fine of $\$ 10,000$ and six months imprisonment. See 29 U.S.C. $\S 666(e)$ (1988). This was not increased in 1990 .

${ }^{326}$ See W. Kip Viscusi, Market Incentives for Safety, HARV. BUS. REv., July-Aug. 1985 at 133, 135; Note, A Proposal to Restructure Sanctions Under the Occupational Safety and Health Act: The Limits of Punishment and Culpability, 91 YALE L.J. 1446, 1457-59 (1982). 
lack of adequate resources; 1181 compliance officers cannot provide adequate inspection. ${ }^{327}$ With such limited resources, the agency cannot even consider what inspections are needed, but can only consider how best to utilize wholly inadequate resources. The root of the problem, of course: the budget. Congress is quite willing to declare its purpose "to insure every working man and woman safe and healthful working conditions," but is unwilling to provide the funds needed to fulfill that purpose. ${ }^{328}$

The effectiveness of OSHA remedies in protecting employees depend in part on the policies of the administration. In 1981, the Reagan administration adopted what it described as a less confrontational approach with greater emphasis on cooperation with employers in getting them to achieve compliance. ${ }^{329}$ Between 1980 and 1982, the total number of inspections decreased only $3 \%,{ }^{330}$ but this figure, however, disguised the true extent of the decrease in the number of inspections, because of an increased emphasis on inspections in the construction industry. When a construction job site is inspected, each contractor and sub-contractor is considered separately. This means that an inspection of a single job site is counted as several inspections, corresponding to the number of contractors and sub-contractors which are on the job. The number of employees covered by inspections was reduced $40 \%$ over this period and the number of violations cited was reduced $25 \%{ }^{331}$ The non-confrontational policy naturally led to smaller fines so that the fines assessed dropped more than $75 \%{ }^{382}$

${ }^{327}$ See supra note 297 and accompanying text.

${ }^{328}$ The first Reagan budget reduced OSHA's budget by nearly 7\%, U.S. DEP'T OF LABOR \& OSHA, REPORT OF THE PRESIDENT TO THE CONGRESS ON OCCUPATIONAL HEALTH AND SAFETY FOR FISCAL YEAR 1981, at 9 (1982) [hereinafter 1981 PRESIDENT's REPORT]. The budget was increased in subsequent years, but the 1989 budget was only about 16\% more than the 1981 budget. See 1988 PRESIDENT's REPORT, supra note 291, at xiv. In the eight years, the non-agricultural work force had increased by $19 \%$, and the value of the dollar had decreased 35\%. See U.S. DEP'T OF COMMERCE, STATISTICAL ABSTRACT OF THE UNITED STATES, 1990, at 384, 478. The net effect was a $25 \%$ reduction in resources for enforcement.

${ }^{329}$ See SIMON, supra note 313, at ii.

${ }^{330}$ See W. Kip Viscusi, The Structure and Enforcement of Job Safety Regulations, LAW \&c CONTEMP. ProBs., Autumn 1986, at 127, 136.

331 See DONAHUE, supra note 308 , at 20,22 . This tells only half the story, because the reductions were largely in serious violations, and willful and repeat violations, indicating a more tolerant attitude toward violations and less concern for the risks to employees. Serious violations were reduced by nearly half, and willful or repeat violations by about $70 \%$. Non-serious violations were reduced by only about $3 \%$. See 1981 PRESIDENT'S REPORT, supta note 328, at 53.

332 See supra note 330, at 139. 
During this period the "records only" inspection was introduced. ${ }^{333}$ In this inspection the compliance officer first examined the employer's accident records for the last two or three years. If those records showed an accident rate less than the national average for manufacturing, no further inspection was made and no employee representative was contacted. By 1983, "records only" inspections counted for $15 \%$ of all inspections. ${ }^{334}$ After four years, not surprisingly, OSHA discovered that employer cooperation included a widespread practice of not reporting all accidents so as to keep their accident rates below the national average, thereby keeping the inspector from going beyond the front office. ${ }^{335}$ Companies such as Union Carbide, Champion International, Chrysler, USX, ${ }^{336}$ DuPont, $^{337}$ General Motors, ${ }^{338}$ Caterpillar, ${ }^{339}$ John Morrell, ${ }^{340}$ and Scott Paper, ${ }^{341}$ were cited for massive underreporting. "Records only" inspections have now been eliminated, but a good accident record may lead to only a "partial inspection"-a "brief walkaround" to survey those areas "believed to have the greatest hazard potential." ${ }^{\text {442 }}$

The record keeping violations marked a change in assessing

353 See Viscusi, supra note 330 , at 140 . Employers are required by statute to "maintain accurate records" of work-related injuries and exposures to potentially toxic materials. 29 U.S.C. $\$ 657($ c).

334 See Viscusi, supra note 330 , at 141 (given 10,400 record check inspections and 58,500 inspections excluding record checks in fiscal year 1983 ).

335 See Underreporting of Occupational Injuries and Its Impact on Workers' Safety: Hearings Before a Subcomm. of the House Comm. on Government Operations, 100th Cong., 1st Sess. 9 (1987). Although meatpacking has the highest injury rate in industry, even above mining and construction, "Records Only" inspections were made of IBP, the largest meatpacker in the industry, until 1987. See id. at 8. The inspection was triggered by a union complaint that the company was keeping two sets of records, and was not completed until March 1987. See id. at 29-30. Inspectors found 1038 wilful underreporting violations and proposed a fine of $\$ 2,590,000$. See Empl. Safety \& Health Guide (CCH) No. 846, at 3 (July 28, 1987). They also found that 400 of the 3,000 employees suffered cumulative trauma disorders because of the excessive speed of the assembly line and assessed an additional fine of $\$ 3,139,900$ for more than 625 health and safety violations. The fines, totalling nearly $\$ 6,000,000$, were settled for $\$ 975,000$. See id.

${ }^{336}$ See Willis J. Goldsmith, Current Developments in OSHA: Willfulness Citations Under the 1986 Record-Keeping Guidelines, 13 EMPLOYEE REL. L.J. 346, 349 (1987).

${ }^{337}$ See Empl. Safety \& Health Guide (CCH) No. 846 (July 28, 1987).

${ }^{338}$ See Empl. Safety \& Health Guide (CCH) No. 857 (Oct. 14, 1987).

339 See Empl. Safety \& Health Guide (CCH) No. 897 (July 19, 1988).

340 See Quigley, supra note 309, at 590-92.

341 See Empl. Safety \& Health Guide (CCH) No. 856 (Oct. 6, 1987).

342 OSHA FIELD OPERATIONS MANUAL, supra note 276, 17962.105 (modifying chapter II.B.5.b.a). 
penalties, as OSHA counted each misreporting as a separate willful violation, and "mega-fines" ranging up to more than two million dollars were proposed. ${ }^{343}$ This method of assessing penalties has since been applied to other willful violations, with proposed fines up to six million dollars. ${ }^{344}$ Although these "mega-fines" are regularly reduced, as are other fines, the amounts paid may still be more than a million dollars. Large fines, however, remain the exception, with the average of proposed fines in 1988 not significantly larger than that of 1988 , when indexed for inflation. ${ }^{345}$ These fines still are not enough to spur corrective action.

Employees may use self-help by refusing to do dangerous work, but the statute provides them only limited protection. Section 11(c) prohibits discrimination against an employee for filing a complaint, instituting a proceeding, testifying, or "because of the exercise by such employee on behalf of himself or others[,] of any right afforded by this chapter. ${ }^{\text {346 }}$ In Whirlpool Corp. v. Marshall, ${ }^{347}$ two workers refused to go out on a wire-mesh screen suspended twenty feet above the ground where two employees had previously fallen through. The Supreme Court held that their refusal was protected by section 11(c), but narrowly circumscribed this right. The condition must be one which the employee "reasonably believes pose[s] an imminent risk of death or serious bodily injury. ${ }^{\text {"348 }}$ The employee must further have "reason to believe that there is not sufficient time or opportunity either to seek effective redress from

${ }^{343}$ See supra note 335.

344 See supra note 335.

${ }^{345}$ Average proposed fines per occurrence (in dollars):

\begin{tabular}{lrrr} 
Type of Violation & 1980 & 1985 & \multicolumn{1}{c}{1988} \\
\hline Serious & $\mathbf{3 0 3 . 4 7}$ & 194.65 & 261.38 \\
Other-than-serious & 2.04 & .55 & 1.64 \\
Willful, repeat & 1947.48 & $\mathbf{8 8 7 . 8 8}$ & $\mathbf{5 2 7 2 . 7 6}$ \\
Failure to abate & $\mathrm{NA}$ & 503.00 & 1029.09 \\
Average of all & 189.26 & $\mathbf{7 6 . 7 7}$ & 290.57
\end{tabular}

See 1988 PRESIDENT'S REPORT, supra note 291, at V-14. It appears that in the last two years OSHA has proposed and enforced more substantial fines, at least in a limited number of extreme cases. See, e.g., Empl. Safety \& Health Guide (CCH) No. 1028, at 2 (Jan. 15, 1991) (stating that ARCO had paid a fine of $\$ 3,481,300$ for an accident in which 17 people were killed); Empl. Safety \& Health Guide (CCH) No. 1062, at 1 (Aug. 27, 1991) (stating that Phillips 66 had paid a $\$ 4,000,000$ fine for a fire and explosion in which 23 workers were killed and 130 injured).

34629 U.S.C. $\$ 660$ (c).

${ }^{347} 445$ U.S. 1 (1980).

${ }^{348} I d$. at 10 . 
his employer or to apprise OSHA of the danger." ${ }^{349}$ The employee's good faith belief either as to the danger or time to appeal to OSHA, will not entitle the employee to protection: the belief must be objectively reasonable. The employee thereby risks a later finding by one not faced with the danger that the belief was not reasonable. ${ }^{350}$ In addition, the employee is not entitled to receive pay for the time lost while refusing to do the work. ${ }^{351}$ Because of these strictures, in the absence of the most imminent danger, employees cannot safely use self-help, but must look to OSHA procedures to protect them. ${ }^{352}$

Potentially, the most effective method of an employee protecting herself from dangerous conditions is filing a complaint with OSHA. Section 11(c), however, provides little assurance of protection from retaliation either for filing a complaint or for refusing dangerous work. ${ }^{353}$ The courts have held that an employee cannot bring suit, but must seek relief by filing a complaint with OSHA. ${ }^{354}$ If, after investigation, OSHA determines that the complaint is without merit, the employee may not appeal except within the Department of Labor. If the complaint is found meritorious, OSHA will attempt to settle. If this fails, the case is referred to the Solicitor of the Department of Labor who decides whether to sue in the District Court. $^{355}$ In 1985, 2433 complaints were filed, but only 291 were found meritorious. ${ }^{356}$ Sixty-seven cases were ultimately sent to the Solicitor, who pursued approximately half of them-a little more than $1 \%$ of the complaints filed. ${ }^{357}$

349 Id. at $10-11$.

${ }^{350}$ See generally Kenneth L. Smukler, Comment, Individual Safety Protests in the NonUnion Workplace: Hazardous Decisions Under Hazardous Conditions, 89 DICR. L. REV. 207, 228-30 (1984) (discussing the ramifications of Whirlpool).

331 See Whirlpool, 445 U.S. at 19.

332 Whirlpool will rarely apply where employees are exposed to health hazards, as opposed to safety hazards, because of its requirement that an employee be exposed to "imminent risk of death or serious bodily injury." 445 U.S. at 10.

${ }^{333}$ See generally Swain, supra note 283, at 96 (criticizing the \$ 11(c) enforcement mechanism); Kevin J. Worthen, Comment, Retaliatory Discrimination Actions Under Section 11(c) of OSHA: Too Many Rights, Not Enough Protection, 1981 B.Y.U. L. REv. 909, 911-12 (discussing the procedure for commencing an action).

${ }^{354}$ See, e.g., Taylor v. Brighton Corp., 616 F.2d 256, 258-63 (6th Cir. 1980)(finding no private right of action under $\$ 11(\mathrm{c})$ ).

355 See Swain, supra note 283, at 94-95.

356 See Eugene R. Fidell, Federal Protection of Private Segtor Health aNd SAFETY WHISTLEBLOWERS: A REPORT TO THE ADMINISTRATIVE CONFERENCE OF THE UNITED STATES A7 (1987).

${ }^{357}$ See id. 
The small proportion of complaints found meritorious and the small number of suits brought apparently reflect the pervasive need to make the most of inadequate resources. In Taylor $v$. Brighton Corp. ${ }^{358}$ discharged employees filed a complaint under section 11(c). The Solicitor, in an amicus brief, urged the court that the employee be allowed to sue because the Department had neither the resources nor the personnel to handle all section 11 (c) complaints, and that individual suits offered the only realistic hope of protecting employees from retaliatory discharge. ${ }^{359}$ The Sixth Circuit's response was that "[t]he Secretary should address his arguments to Congress, not the courts." 360 The response of Congress was to provide OSHA a smaller budget for the following year than the year before. ${ }^{361}$ This case epitomizes the failure of OSHA to "assure so far as possible every working man and woman in the Nation safe and healthful working conditions. ${ }^{\text {\$62 }}$ Total reliance for protecting the declared rights of employees is placed in an agency which is denied by Congress the needed resources, and by an administration which apparently lacks the affirmative will to provide effective protection. ${ }^{363}$

\section{B. Workers' Compensation}

The employee's right to compensation for work-related injuries is enforced through fifty independent state agencies and three federal agencies. ${ }^{364}$ Because of differences in both the substantive provisions and the varied administrative procedures utilized by each of these agencies, generalizations may mask wide variations. In addition, because the fifty-three agencies have no standard system of record keeping or data collection, aggregate data may not only

${ }^{358} 616$ F.2d 256 (6th Cir. 1980).

359 See id. at 263.

$360 \mathrm{Id}$. at 264.

361 See 1981 PRESIDENT'S REPORT, supra note 328, at 9 (showing appropriations of $\$ 209,376,000$ in 1981); U.S. DEP'T OF LABOR \& OSHA, REPORT OF THE PRESIDENT TO THE CONGRESS ON OCCUPATIONAL SAFETY \& HEALTH FOR FISCAL YEAR 1982, at 3 (1983) (showing appropriations of $\$ 195,430,000$ in 1982).

36229 U.S.C. $\$ 651(\mathrm{~b})$.

363 The $\$ 11$ (c) remedy also suffers from the more common inadequacies of court delay, lack of interim reinstatement, and the seeming lack of understanding or sympathy by district courts.

$\$ 64$ See U.S. CHAMBER OF COMMERCE, 1990 ANALYSIS OF WORKERS' COMPENSATION LAWS vii (1990) [hereinafter 1990 ANALYSIS]. The three federal plans are for the District of Columbia, federal employees, and longshore and harbor workers. See id. For a comparative overview of the various statutes, see $i d$. at 3-45. 
contain distortions, but also may not provide an accurate picture of any individual state or federal program. ${ }^{365}$

Despite differences, all workers' compensation systems make the employer strictly liable to its employees for work-related injuries, commonly described as "accidents arising out of and in the course" of employment. ${ }^{366}$ The employer is liable for all medical costs and must pay statutorily prescribed benefits for physical disability, loss of earnings and death. The employer may also be liable for costs of rehabilitating the injured worker to employability. ${ }^{367}$ Many minor work accidents do not lead to workers' compensation proceedings. Employees are often given basic first aid or medical attention at the workplace. If an employee visits her own doctor after a minor incident, the physician will simply send the bill to the employer. An employee may be then given paid leave or light work until able to return to a regular job. ${ }^{368}$

Typically, workers' compensation proceedings begin with the employee notifying the employer, the appropriate agency, or both, of an injury. Failure to give notice in the time specified by the applicable law- "immediately," "as soon as practicable," and "within 30 days" are three of the more commonly used statutory phrasesmay bar the employee from claiming benefits retroactively to the date of the injury, or from filing a claim later. ${ }^{369}$ The second step is filing a claim with the agency, for which there is a much longer time limit-commonly one or two years. If the employer or its insurance carrier contests the claim, it will be set down for a hearing before an administrative law judge, referee or arbitrator employed by the agency, who will then issue an award. This award may be appealed administratively to a board or commission, whose decision is subject to judicial review. ${ }^{370}$

${ }^{365}$ See Ronald Conley \& John Noble, Workers' Compensation Reform: Challenge for the 80's, in 1 RESEARCH REPORT OF THE INTERDEPARTMENTAL WORKERS' COMPENSATION TASK FORCE 147-48 (1979).

${ }^{366}$ John D. Worrall, Compensation Costs, Injury Rates, and the Labor Market, in SAFETY AND THE WORK FORCE 1 (John D. Worrall ed., 1983).

${ }^{367}$ For a summary of benefits, see 1990 ANALYSIS, supra note 364, at 17-29.

${ }^{368}$ See Lois R. Sincere, Processing Workers' Compensation Claims in Illinois, 1982 AM. B. FOUND. RES. J. 1073, 1081 (suggesting that many injuries are not accounted for due to poor record keeping). About $80 \%$ of all cases involve only medical benefits. See Conley \& Noble, supra note 365 , at 45.

${ }^{369}$ See, e.g., CAL. LAB. CODE $\$ 5400$ (West 1992) ("within 30 days"); GA. CoDE ANN. \$ 34-9-80 (1992) ("immediately" or "as soon thereafter as practicable"); IDAHO CODE \& 72-701 (1992) ("as soon as practicable but not later than sixty (60) days").

370 For a comprehensive description of the specific procedures followed in processing claims in each state, see generally U.S. DEP'T OF LABOR, STATE WORKERS' 
Permanent partial or permanent total disability and death benefits constitute only a small percentage of all workers' compensation claims, but are the most frequently contested. The great majority of all cases only involve the payment of medical benefits. ${ }^{371}$ Relatively few of these cases are contested. In addition, only $3 \%$ of cases involving temporary partial disability and $8 \%$ of temporary total disability cases are contested. ${ }^{372}$ Because the loss of earnings is temporary, the insurance carriers find it is not economical to contest these smaller claims, although they raise the same legal issues as permanent disability cases-compensability of the accident and degree of impairment. ${ }^{373}$ In contrast, $33 \%$ of permanent partial disability cases, over $50 \%$ of the permanent total disability cases, and $40 \%$ of the death benefit cases are contested. ${ }^{374}$ The result is that the bulk of contested cases involve claims for permanent disability, partial or total, or death, which by their nature involve substantial sums of money.

Of the contested cases, nearly two-thirds are settled by agreement prior to the first level hearing. ${ }^{375}$ Only a small percentage are appealed to a higher administrative level or to a court. Although there are wide variations from state to state, ${ }^{376}$ the national average of contested cases going to a second level of hearing was less than $4 \% .^{377}$

Settlements without a hearing, although expeditious resolutions of contested claims, are not an unblemished virtue, for they may be obtained at the expense of the injured employee. The insurance carrier is always represented by a lawyer experienced in workers' compensation, but the employee is sometimes unrepresented, particularly when approached by the carrier representative with an

Compensation: Administrative Profiles (1987) [hereinafter State Profiles]. 371 See MONROE BERKOWITZ \& JOHN F. BURTON, JR., PERMANENT DisabiLTTY BENEFITS IN WORKERS' COMPENSATION vii (1987); see also Conley \& Noble, supra note 365 , at 45 .

372 See Merton C. Bernstein, Litigation, Representation and Claimant Protection in Workers' Compensation, in 1 RESEARCH REPORT OF THE INTERDEPARTMENTAL WORKERS' COMPENSATION TASK FORCE, supra note 365, at 115, 129.

${ }^{373}$ See $i d$. at 130 (discussing the cost-benefit calculus facing insurers).

374 See id. at 129.

375 See id. at 131 .

${ }^{376}$ A 1978 survey of nearly 6000 cases in Illinois found that $6 \%$ were appealed to administrative review and less than $1 \%$ reached judicial review. See Sincere, supra note 368 , at 1087 .

377 See Bernstein, supra note 372 , at 132. 
offer of settlement. ${ }^{378}$ In cases of permanent disability or death, where substantial amounts are at stake, roughly $40 \%$ of the claimants have no lawyer and in temporary disability cases, $95 \%$ of the injured workers are unrepresented. ${ }^{379}$ Because of the danger of overreaching by the carrier, some states require that all settlements be approved by the referee or some other official. ${ }^{380}$ This supervision, however, is often superficial, leaving the uninformed employee at the mercy of the carrier's representative. ${ }^{381}$

That most cases are either settled by the parties or resolved at the first hearing level does not mean that injured employees receive monetary benefits quickly. In uncontested disability cases, it takes an average of nearly six weeks from the start of lost work time until the employee receives the first check, and in uncontested death cases it takes an average of four and a half months. In contested disability cases it takes an average of more than five months before the employee receives the first check, and in contested death benefits it takes an average of about eighteen months. ${ }^{982}$

These averages, however, conceal the delay which characterize many cases. If the case is not settled and goes to hearing, the delay in payment in disability cases averages more than fourteen months. ${ }^{383}$ In cases where the issue is whether the injury is workrelated, the delay is substantially longer. ${ }^{384}$

The crucial importance of delay is that in most states the injured employee receives nothing until there is a settlement or award. The

378 See Sincere, supra note 368 , at $1088 \&$ n.50.

${ }^{379}$ See Bernstein, supra note 372, at 124. Some states allow persons other than lawyers to represent claimants. See, e.g., MASS. GEN. L. ch. 152, § 7(c) (Supp. 1992) ("Any party . . . may be represented by an attorney or by any other person designated by such party."). Only approximately one percent of representation, however, is done by non-lawyers. See Bernstein, supra note 372, at 124 .

${ }^{380}$ See, e.g., Conley \& Noble, supra note 365, at 103-04 ("The appropriate and legitimate way of resolving disagreements between the claimant and the carrier is by providing a prompt hearing .....").

${ }^{381}$ See Sincere, supra note 368, at 1085 (describing how, in Illinois, carriers' attorneys have "dominated the [settlement] procedure"); see also STATE PROFILES, supra note 370 , at 1-414 (detailing each state's procedures for supervision of settlements).

382 See Conley \& Noble, supra note 365 , at 57.

383 See id. at 58. In Illinois, a claim is scheduled for first hearing about three months after it is filed, but this is only a "status" call, and there is an automatic continuance of three or four months. There are often additional continuances, which are granted routinely. Once the hearing is completed, it is three or four months before a decision is issued. Nearly $10 \%$ of the cases take more than three years to be resolved. See Sincere, supra note 368, at 1086, 1092-94.

${ }^{381}$ See Conley \& Noble, supra note 365 , at 59. 
delay in obtaining a hearing is used to pressure the employee, with mounting medical bills and no income, to settle for substantially less than the full value of the claim. ${ }^{385}$ There is some evidence that carriers contest cases and carry them to hearing for the purpose of exerting this pressure. ${ }^{386}$

The principle weakness of workers' compensation remedies is the inadequacy of benefits for lost wages. Typically, weekly benefits for the period the employee is disabled are computed at two-thirds of the injured employee's prior average wage, with a maximum weekly benefit based on the state's average weekly wage. ${ }^{387}$ Only two-thirds of the wage loss are paid to discourage malingering and encourage the injured employee to return to employment. ${ }^{388}$ This reduction in wages, of course, penalizes those who are genuinely unable to return to work. Scheduled benefits pay a fixed number of lost work weeks in cases of dismemberment, such as loss of a finger, hand, foot, or leg, regardless of actual wage loss. In some cases these payments are grossly unfair because the dismemberment may totally incapacitate the person for her occupation. Once the predetermined number of benefit weeks expire, the worker is without any income. ${ }^{389}$ In addition, the maximum weekly benefit is most commonly fixed at $100 \%$ of the statewide average wage, with the result that those earning higher wages or salaries will receive less than two-thirds of their wage loss. ${ }^{390}$

385 See STATE OF NEW YORK, FINAL REPORT OF THE TEMPORARY COMMISSION ON WORKERS' COMPENSATION AND DISABILITY BENEFTTS 46, 109 (1986) (stating that due to desperation, claimants often accept lump-sum settlements which range from onehalf to one-fourth of the present value of their expected benefits ) [hereinafter NEW YORK FINAL REPORT]; see also Conley \& Noble, supra note 365, at 99, 103.

${ }^{386}$ See NEW YORK FINAL REPORT, supra note 385, at 69 n.62 (stating that only $38 \%$ of carriers' appeals on the issues of "classification, extent and period of disability" were at all successful).

${ }^{387}$ See 1990 ANALYSIS, supra note 364 , at 18-21. The employee's wages do not include fringe benefits paid by the employer, which may be more than $25 \%$ of earnings. Particularly serious is the loss of pension payments, health care, and social security. See Conley \& Noble, supra note 365, at 75-76.

${ }^{388}$ See Monroe Berkowitz, Workmen's Compensation Income and Benefits: Their Adequacy $\mathcal{E}^{2}$ Equity, in 1 SUPPLEMENTAL STUDIES FOR THE NATIONAL COMMISSION ON STATE WORKMEN'S COMPENSATION LAWS 189, 191 (1973).

389 The number of weeks of benefits for the loss of a hand is the same for a secretary, a janitor and a lawyer; the number of weeks' benefits for loss of a first finger on the left hand is the same for a violinist, a bank clerk and a truck driver; and the benefits for loss of a leg is the same for an artist as it is for a professional athlete. See BERKOWITZ \& BURTON, supra note 371, at 110 (listing the predetermined number of benefit weeks for various injuries, regardless of ability to return to work after benefits expire).

${ }^{390}$ This may be partially offset because compensation benefits are not taxable 
Most seriously, particularly for the long term or permanently disabled, is that the weekly benefits are determined as of the time of injury. Most states make no provision for changes in wage loss due to inflation or the employee's normal lifetime earnings curve. As a result, the benefit for those with permanent disabilities may, after several years, be only a fraction of their actual wage loss. ${ }^{391}$

The injured employee's right to rehabilitative treatment, where it exists, has limited value. Lawyers often advise employees not to accept rehabilitation until their case is settled because it may reduce the amount of the settlement-and the amount of the lawyer's fee. ${ }^{392}$ Carriers do not encourage rehabilitation because their dominant incentive is to settle the case and avoid future responsibility for rehabilitation and its administrative costs. ${ }^{393}$ Obviously, delay in starting rehabilitation significantly reduces the likelihood of its success. Rehabilitation services are generally insufficient, screening procedures to identify employees who would benefit are inadequate, employees are not informed of their options, and delays from administrative procedures and waiting lists further discourage injured employees. As a result, the number of those enrolled is a small percentage of those in need of rehabilitation. ${ }^{394}$

The adequacy of the employee's remedy is further reduced by the need to pay lawyers' fees. ${ }^{395}$ As originally conceived, the compensation agency was to be the active guardian of the employee's right, making it unnecessary for a claimant to be represented by counsel. ${ }^{396}$ This, however, has proven to be a naive hope. The procedure as it has developed is adversarial because of the employers' and carriers' desire to reduce costs by contesting claims. For this reason and because of time pressures, hearing officers cannot simultaneously represent the claimant and judge the merits of the case. ${ }^{397}$ Employees cannot effectively represent themselves in

income. See I.R.C. \$ 104(a) (1988).

391 For a discussion of the adequacy of benefits, see Conley \& Noble, supra note 365 , at $63-79$. Death benefits only replace $36 \%$ of the lost income for the surviving spouse. See William G. Johnson \& Edward Heler, Compensation for Death from Asbestos,

37 INDUS. \& LAB. REL. REV. 529, 532 (1984).

${ }^{392}$ See Conley \& Noble, supra note 365 , at 86-87.

393 See id.

394 See generally id. at 81-88.

${ }^{395}$ A few states require the employer or its carrier to pay the employee's attorneys' fees, but in most states the employee must pay her own lawyer. See Bernstein, supra note 372 , at 133-34.

${ }^{396}$ See id. at 121 ('[T] claimant's protector (perhaps advocate) as well as impartial arbiter of his claim.").

${ }^{397}$ See $i d$. (noting that various pressures preclude a hearing officer from 
contested cases because the legal doctrines, the problems of proof, and the procedure have become complex. This leaves claimants with no real option but to employ counsel. Indeed, lawyers not familiar with the specialized practice have difficulty representing a claimant effectively, ${ }^{398}$ and the practice is limited to a relatively small club of lawyers who specialize full time in representing injured employees in compensation proceedings. ${ }^{399}$

Attorneys' fees are controlled either by statute or by the agency. The fees allowed are relatively low with the typical amount being $20 \%$ to $25 \%$ for the first $\$ 5000$, and a smaller percentage for larger amounts, based on the value of the whole cash award, excluding medical costs. ${ }^{400}$ Attorneys appear in only $5 \%$ of the temporary disability cases, at least in part because the small awards cannot produce an adequate fee..$^{401}$ Even in permanent disability and death cases, in which awards are more substantial, the fee is relatively small. One consequence is that lawyers must handle a large number of cases with relatively little time devoted to each. Lawyers may handle ten to twenty cases in a single day, often not securing photographic evidence, arranging for medical testimony or rehearsing the claimant's testimony. ${ }^{402}$ Flat percentage fees encourage lawyers to settle for a lump sum in order to minimize their efforts and obtain early payment. ${ }^{403}$ Although attorneys' fees are relatively low-too low to reward high quality legal effortpayment of these fees by the injured claimant significantly reduces the already inadequate recovery. The two-thirds recovery of wage loss is reduced to a net of little more than one-half of the actual wage loss.

All of the inadequacies of workers' compensation remedies are magnified in occupational disease cases. ${ }^{404}$ In these cases the

undertaking the multiple functions originally intended).

${ }^{398}$ See id. at 123-26 (noting that "great familiarity with a large and intricate set of agency and court-constructed precedent and the procedures of medical institutions, insurers and agencies are required for competent representation").

${ }^{399}$ See Sincere, supra note 368 , at 1089 (describing the Illinois workers' compensation bar as a "fraternity").

${ }^{100}$ See Bernstein, supra note 372, at 137.

401 See id. at 142 (noting the difficulty claimants encounter'when attempting to retain counsel for smaller claims).

402 See id. at 127.

403 NEW YORK FINAL REPORT, supra note 385, at 47; See Conley \& Noble, supra note 365 , at 105 .

104 See generally Bernstein, supra note 372, at 144-45 (noting "the difficulty of ascribing causation to a particular employer"); Note, Compensating Victims of Occupational Disease, 93 HARV. L. REV. 916, 921-25 (1980) (noting that problems of 
proof problems are much more difficult due to the need to show the specific source of the disease at the workplace and to show the employee's exposure within time limits frequently specified by the statute. A high percentage of these cases are contested-as many as $88 \%$ for dust-related diseases and $86 \%$ for repeated trauma injuries such as hearing loss. ${ }^{405}$ The high rate of contested cases results in greatly extended delays for employees in receiving benefits. ${ }^{406}$

Although the employees' remedies under workers' compensation have obvious weaknesses, they are in some respects better than the remedies for other employee rights which have been discussed. Delay in recovery is painful, but a delay of six weeks in uncontested cases, and five months in contested cases with fourteen months for a decision after a hearing outpaces the NLRB, puts the EEOC to shame and leaves the unjust discharge cases in the starting gate. The burden of attorneys' fees, which are avoided in the NLRB and shifted in the EEOC and Wage-Hour cases, are substantially less than the contingent fee agreements in wrongful discharge cases. An injured employee has far less difficulty obtaining a lawyer or proceeding pro se than an employee who is victimized by discrimination or underpayment and is not dependent on an agency's general counsel to support the claim. Although the legal service obtained is not high quality, it may be adequate in most cases. Studies show that in contested cases, claims were denied in less than $4 \%$ of the cases, modified in less than $20 \%$ and settled by agreement in over $60 \% .{ }^{407}$ Overall, despite delays and inadequacies, most employees who had meritorious claims received some monetary award.

Another positive aspect of workers' compensation is that it is constructed so as to encourage employers to reduce the number of accidents. Except for employers with less than four employees, the employer's insurance rates are generally merit rated, scaled according to the claims paid. ${ }^{408}$ The cost of accidents is thus largely internalized, pressuring the employer to take whatever safety

proving "that the resulting injury arose out of employment ... pose an immense challenge").

105 See Conley \& Noble, supra note 365 , at 110-11.

106 The average delay from the filing of a claim to the first payment was $\mathbf{3 9 0}$ days, as compared with 43 days for the typical accident claim. See Note, supra note 404 , at 923.

407 See Conley \& Noble, supra note 365, at 100.

408 See id. at 134-36. Ninety percent of all premiums are experience rated. See id. at 135-36. 
measures will cost less than the accidents they will avoid. ${ }^{409}$ Although there is debate about whether this insurance rating scheme provides a sufficiently substantial incentive, ${ }^{410}$ it does provide a much greater economic incentive for safety efforts than the limited and random fines of OSHA.

Compared with the other procedures which have been discussed, workers' compensation has significantly lower transaction costs. A much larger portion of money paid out by the responsible employer reaches the injured employee. In 1987, the national ratio of benefits paid per $\$ 1$ of employer cost was 69 cents, ${ }^{411}$ and that figure was the lowest in five years. ${ }^{412}$ From this figure must be deducted the employees' lawyers' fees, which on the average for all workers' compensation claims, amounts to less than $4 \%$ of benefits. ${ }^{413}$ The result is that the employee nets between $65 \%$ and

${ }^{409}$ Premiums charged do not exactly parallel benefits paid. A portion is reserved to insure against large losses and a portion is allocated for administrative expenses. Furthermore, the merit rating formula gives greater weight to the number of claims than the amount of the benefits. See generally Richard B. Victor, Experience Rating and Workplace Safety, in WORKERS' COMPENSATION BENEFITS: ADEQUACY, EQUITY, AND EFFICIENCY 71, 72 (John D. Worrall \& David Appel eds., 1985) (discussing the financial incentives in workers' compensation for employers to prevent injuries and diseases).

${ }^{410}$ See, e.g., James R. Chelius, The Influence of Workers' Compensation on Safety Incentives, 35 INDUS. \& LAB. REL. REV. 235, 241 (1982) (discussing the "dysfunctional impact" of increased injuries that arguably results from workers' compensation); William S. Maakestad \& Charles Helm, Promoting Workplace Safety and Health in the Post-Regulatory Era: A Primer on Non-OSHA Legal Incentives That Influence Employer Decisions to Control Occupational Hazards, 17 N. KY. L. REv. 9, 21-25 (1989) ("The empirical findings comparing wage-risk differentials and workers' compensation incentives are mixed at best." ); John D. Worrall \&e Richard J. Butler, Labor Market Theory and the Distribution of Workers' Compensation Losses, in WORKER's COMPENSATION INSURANCE PRICING 19, 19 (David Appel \& Phillip S. Borba eds., 1988) (describing a statistical study of "how changes in the benefit structure . . . and in experience rating affect claims").

${ }^{411}$ See William J. Nelson, Jr., Workers' Compensation: Coverage, Benefits and Costs, 1987, Soc. SEC. Bull., Apr. 1990, at 2, 7.

412 The loss ratio (the proportion of the premium dollar returned to the injured worker in the form of cash payments and medical services) in 1984 was $73 \%$ and in 1985, 72\%. William J. Nelson, Jr., Workers' Compensation: Coverage, Benefits and Costs, 1985, SOC. SEC. BULL., Jan. 1988, at 4, 9. The national loss ratio includes insurance obtained through private carriers, state and federal programs, and self-insurance. See $i d$. The loss ratio for state funds is much higher. In 1985, for example, the loss ratio for eighteen state funds was $91 \%$. See id.

${ }^{413}$ The average legal fee award in New York in 1982 was $\$ 445$, and the total awarded was $3 \%$ of the total compensation. See New York Workers' Compensation Bd., Compensation Cases Closed, 1982, in RESEARCH AND STATISTICS BulletiN 1, 13 (1982). In Michigan, legal fees amounted to $4 \%$ of the total cost of the system. See Bernstein, supra note 372, at 138. 
$70 \%$ of the premiums paid by the employer. This should be compared with the $30 \%$ received by the median employee in wrongful discharge cases. ${ }^{414}$ Although no hard data is available for the Wage-Hour and EEOC cases, the costs of litigation compared to the amounts received by the employee ${ }^{415}$ are more similar to those in the wrongful discharge cases, further highlighting workers' compensation's relative advantage.

\section{Collective Contract Remedies}

The nearly universally accepted procedure for adjudicating and enforcing rights under collective agreements is the union grievance procedure, with ultimate resort to arbitration. ${ }^{416}$ This procedure is used for enforcing not only the collective or institutional rights of the union, but the whole range of contractual rights of individual employees, including claims of unjust discharge, claims for wages, vacation and holiday pay, and complaints about working conditions, sick leave, health and welfare benefits, promotions, transfers, and layoffs. ${ }^{417}$

From the standpoint of the individual employee, the grievancearbitration procedure has marked advantages. First, the individual bears none of the costs; her union dues provide what amounts to group legal services for contractual rights. The union provides the cost of advocacy at both the grievance and arbitration level, whether by union representative or a lawyer, along with the share of arbitration costs and fees. In addition, the union collects the necessary evidence, obtains the needed witnesses, and takes whatever steps are necessary to enforce a favorable award. The lowest wage and least capable employees are thus protected.

Second, arbitration is relatively prompt. The average time between the filing of a grievance and the issuing of an award is

414 See supra notes $52-53$ and accompanying text.

415 The public costs of administration is relatively small, apparently between $1 \%$ and $3 \%$ of the benefits paid. Some states assess insurers a percentage of premiums, for instance, $2 \%$ in Florida. States levying assessments have nearly doubled the resources for administration. See Milton Brooke, Administering Workmen's Compensation Cases in Califormia, Florida, Massachusetts, New Jersey, New York, and Wisconsin, in 3 SUPPLEMENTAL STUDIES FOR THE NATIONAL COMMISSION ON STATE WORKMEN'S COMPENSATION LAWS 77, 92 (Monroe Berkowitz ed., 1973).

${ }^{416}$ See 2 Collective Bargaining Negot. \& Cont. (BNA) 51:5 (Jan. 23, 1992) ("Arbitration is called for in 99 percent of the sample contracts . . ..").

417 See 43 FEd. MEdiation \& Conciliation SERV. ANN. ReP. 44 (1991) [hereinafter FMCS RELEASE]. 
about eleven months. ${ }^{418}$ Although occasional cases may drag out for more than a year, some collective agreements provide for expedited procedures, particularly for certain kinds of cases. ${ }^{419}$ Both the anthracite and bituminous coal agreements require discharge cases to be heard by the arbitrator and decided within fifteen days. ${ }^{420}$ Finality is seldom delayed by appeal of the arbitrator's award, for the number of awards appealed to the courts is less than $.5 \% .^{421}$ When awards are appealed, the median time for a court decision is one year. ${ }^{422}$

One disadvantage to the individual employee of the grievancearbitration procedure is that it is controlled by the union, and the individual is bound by the union's decision not to arbitrate, if that decision is made fairly and in good faith. ${ }^{423}$ The union may, of course, have limited resources so that not all meritorious claims can be carried to arbitration. Most unions, however, feel morally and politically obligated to carry all substantial cases to arbitration. They give priority to the point of impoverishment to contest unjust dismissals and substantial discipline, often following the policy of carrying any discharge case to arbitration if the employee requests.

From the standpoint of both the union and the employer, the grievance-arbitration procedure has additional values. First, it provides a structured negotiation process which encourages early

${ }^{418}$ See id. at 43 . The average time between the date the grievance is filed and an arbitration panel is requested is 95 days, and the time between a request for a panel and the issuance of an award averages 231 days. Id. The American Arbitration Association statistics for 1990 show an average of 266 days from the time a panel is requested to when an award is issued. See Labor Cases Awarded 1990, STUDY TIME, No. 4 , 1991, at 2.

${ }^{419}$ See Cornelius J. Peck, Report on a Survey of Academy Members on Expedited Arbitration, in ARBITRATION 1985: LAW AND PRACTICE 265, 270 (Walter J. Gershenfeld ed., 1986) (finding that approximately $66 \%$ of expedited cases were mandated by the collective bargaining agreement).

420 See Anthracite Wage Agreement of 1990 art. 19, § (c); National Bituminous Coal Wage Agreement of 1988 art. XXIV § (d) (requiring arbitration hearing and decision within five days, with the arbitrator issuing a written opinion not more than ten days later).

421 In 1987, there were an estimated 78 district court decisions involving an appealed award and nearly 10,000 awards issued under Federal Mediation and Conciliation Service (FMCS) and American Arbitration Association (AAA) auspices. Peter Feuille \& Michael LeRoy, Grievance Arbitration Appeals in the Federal Courts: Facts and Figures, ARB. J., Mar. 1990, at 41.

422 See id. at $45-46$.

${ }^{423}$ See Vaca v. Sipes, 386 U.S. 171, 191 (1967) ("[W]e do not agree that the individual employee has an absolute right to have his grievance taken to arbitration regardless of the provisions of the applicable collective bargaining agreement."). 
investigation of the facts and maximizes the chance of settlement before any litigation begins. ${ }^{424}$ Discharges may be reduced to short term suspensions and lesser disciplinary penalties may be mitigated. Even minor actions such as warning notices may be considered and adjusted, while other claims may be resolved or compromised. However, the demand for arbitration does not end the negotiation process. Less than $20 \%$ of the cases in which arbitration is requested proceed to an award; over $80 \%$ are resolved prior to a hearing. ${ }^{425}$

Second, the arbitration procedure is simple and inexpensive. There are no formal pleadings, no discovery or depositions, no motions for summary judgement, no post trial motions, few subpoenas, and no technical rules of evidence. The issue is addressed directly in an informal hearing, which only occasionally lasts more than one day. ${ }^{426}$ The procedure does not require a lawyer, and can instead be competently handled by a union representative or a personnel officer. Lawyers, however, are increasingly used by both employers and unions. ${ }^{427}$

The inclusion of lawyers, with their habits and practices, adds substantially to the costs and delays of arbitration, with doubtful improvement in the process. An empirical study suggests that if only one party is represented by a lawyer, the likelihood of that party's success increases, but if both parties are represented, the likelihood of one party winning is the same as if neither party were represented. ${ }^{428}$ The study recommends that the parties could

124 At General Motors in the 1950 s only $4 \%$ of 10,800 grievances reached arbitration. Gabriel N. Alexander, Impartial Umpireships: The General Motors-UAW Experience, in ARBITRATION AND THE LAW 108, 129 (Jean T. McKelvey ed., 1959). The experience at Chrysler was much the same. See David A. Wolff et al., The ChryslerUAW Umpire System, in THE ARBITRATOR AND THE PARTIES 111, 117 (Jean T. McKelvey ed., 1959) (averaging less than 23 decisions per year from 1943 through 1957).

${ }^{425}$ In 1990, the Federal Mediation and Conciliation Service received 27,363 requests for arbitrations but only 5275 awards were issued. See FMCS RELEASE, supra note 417 , at $43-45$. In 1989 , there were 27,213 requests and 3769 awards. See id.

${ }^{426}$ See id. at 43 (average hearing time 1.11 days in 1990).

${ }^{427}$ In 1984, employers used lawyers in nearly three-fourths of cases, and unions used lawyers in one-half of the cases. See Richard N. Block \& Jack Stieber, The Impact of Attomeys and Arbitrators on Arbitration Awards, 40 INDUS. \& LAB. REL. REV. 543, 543 (1987). In 1991, employers used lawyers in $83.2 \%$ of cases and unions used lawyers in $59.0 \%$ of cases. American Arbitration Association Reports on Labor Arbitrations, Personnel Pracs. Newsl. (Townley \& Updike, New York, N.Y.), Feb. 1992, at 15 [hereinafter, $A A A$ on Labor Arbitration].

${ }^{428}$ See Block \& Stieber, supra note 427 , at 554 . 
save money by both parties agreeing not to use lawyers. ${ }^{429}$ Using court reporters and filing post-hearing briefs ${ }^{430}$ also add to the cost with little value added in most cases. ${ }^{431}$ Delay is substantially increased by the need to find a hearing date mutually acceptable to the lawyers as well as the parties and the arbitrator, and posthearing briefs may add about two months to the time needed to obtain an award. ${ }^{432}$

The costs of arbitration, even when lawyers are used, are only a fraction of the costs of either judicial or administrative procedures, even though the parties rather than the public pays for the cost of the tribunal. The tribunal costs shared by the parties, which include the arbitrator's fee, travel expenses and other costs, are generally between $\$ 1400$ to $\$ 1800.433$ The lawyer's fees are much less than in other procedures, because the arbitration is unencumbered by pre-and post-trial processes and motions. Using hourly rates, union lawyers report fees in a discharge case ranging from $\$ 2500$ to $\$ 5000.434$ This compares with their fees in an NLRB proceeding for discriminatory discharge of roughly double the amount for arbitration, and in an employment at will case or a Title VII case which goes to trial of $\$ 50,000$ to $\$ 75,000 .^{435}$ Employer lawyers' fees, though $50 \%$ to $100 \%$ higher than those of union lawyers, show much the same pattern of relative costs of the different proce-

${ }^{429}$ See id.

${ }^{430}$ Transcripts are taken in one-third of the cases and briefs are filed in threefourths of the cases. See FEDERAL MEDIATION \& CONCILIATION SERVICE, ARBITRATION STATISTICS FISCAL YEAR 1989, at 4 [hereinafter FMCS STATISTICS]. In American Arbitration Association cases, transcripts are made only in one-fourth of cases, and briefs filed in only two-thirds of cases. See AAA on Labor Arbitration, supra note 427 , at 15 .

${ }^{431}$ See Daniel F. Jennings \& A. Dale Allen, Jr., Labor Arbitration Costs and Case Loads: A Longitudinal Analysis, 41 LAB. L.J. 80, 85 (1990). Twenty-nine percent of arbitrators would eliminate court reporters, $63 \%$ would eliminate post-hearing briefs, and only $3 \%$ would eliminate attorneys. Eleven percent preferred to hear cases presented by non-lawyer representatives while $30 \%$ preferred lawyers and $58 \%$ percent thought it made no difference. See id.

432 See FMCS STATISTICS, supra note 430 , at 1 . The average time between the hearing and the date of an arbitrator's award in 1990 was 64.87 days. FMCS RELEASE, supra note 417 , at 43 .

${ }^{433}$ In 1990, for a Federal Mediation and Conciliation Service arbitrator, the average fees were $\$ 1612.56$, expenses were $\$ 208.04$, for an average total of $\$ 1820.60$. See FMCS RELEASE, supra note 417, at 43. American Arbitration Association figures for 1991 show an average per diem fee of $\$ 465$ with an average fee of $\$ 1764$ and total cost of $\$ 1901$. See Labor Case Distribution and Fees in 1990, STUDY TIME, 1991, No. 4, at 2.

434 These estimates are based on my conversations with practitioners.

435 See supra note 434. 
dures. ${ }^{436}$

The remedies available to arbitrators are, in principle, nearly unlimited, for the courts have stated that in the absence of contractual limitations, arbitrators have broad discretion in designing the remedy. ${ }^{437}$ In practice, however, the remedies are quite limited, seldom going beyond specific future performance of the contractual obligation and compensating employees for any loss of earnings or benefits. ${ }^{438}$ In wrongful discharge cases, reinstatement, with or without back pay, is the customary remedy. ${ }^{439}$ Reinstatement substitutes for potential loss of future earnings, and in most cases is an effective remedy because the union is present to protect the employee in the future. Studies show that a majority of those who return to work under an arbitrator reinstatement order remain and become satisfactory employees. ${ }^{440}$ Employees who are reluctant to return to work, whether because of employer hostility or because they have found another job, may use the reinstatement order to negotiate a "buy-out" with the employer.

Arbitration remedies, limited to specific performance and lost wages, are often incomplete. An employee who is subjected to racial or sexual harassment receives no compensation; the employer is simply told to put an end to the practice. Similarly, an employee ordered to do work outside her classification or work she believes

436 No systematic study of lawyers' fees for arbitration cases is available. The approximate figures used here are based on figures provided to me by a limited number of lawyers regularly involved in representing parties in arbitration.

${ }^{437}$ See United Steelworkers v. Enterprise Wheel \& Car Corp., 363 U.S. 593, 597 (1960) (holding that arbitrator has need for flexibility in formulating remedy).

438 See FRANK ELKOURI \& EDNA A. ELKOURI, HOW ARBITRATION WORKS 288 (4th ed. 1985) (recognizing difference between possession of power and occasion for its use).

${ }^{459}$ See id. at 688; see generally David E. Feller, Remedies in Arbitration: Old Problems Revisited, in ARBITRATION ISSUES FOR THE 1980S, at 109, 110 (1982) (espousing view that arbitrators are "contract readers" and not "contract enforcers"); Anthony V. Sinicropi, Remedies: Another View of New and Old Problems in ARBITRATION ISSUES FOR THE 1980s, supra, at 134 (cataloguing how arbitrators have decided the issue of remedies in a variety of situations).

140 See Thomas J. McDermott \& Thomas H. Newhams, Discharge-Reinstatement: What Happens Thereafter, 24 INDUS. \& LAB. REL. REv. 526, 533-37 (1971) (finding that more than $50 \%$ of reinstated employees rated at least satisfactory on a five point scale); Arthur M. Ross, The Arbitration of Discharge Cases: What Happens. After Reinstatement, in CRITCAL IsSUES IN LABOR ARBITRATION 21, 24 (Jean T. McKelvey ed., 1957) (discussing divergent but untested theories regarding the likely success of the subsequent career of a reinstated employee); but see West, supra note 31, at 30 (finding that only $21 \%$ of those actually reinstated remained on the job two years after reinstatement). The experience in NLRB reinstatement cases is quite the opposite. See supra notes 111-13 and accompanying text. 
dangerous may be obligated to obey on pain of discipline, but will recover no damages. An employee wrongfully discharged recovers nothing for losses suffered as a result of being without income pending arbitration, such as repossession of his car, dispossession from his apartment, or foreclosure on his mortgage. Nor is there any recovery for the emotional trauma which commonly results from job loss, and which is particularly severe when the discharge carries an unjust accusation of wrongdoing or poor performance.

Whatever may be the inadequacy of arbitration remedies, these have been widely accepted by unions. Although unions at times complain about arbitration awards which only tell the employer not to do it again, they have not articulated substantial protests against the limited remedy for unjust discharge. Nor have arbitrators seriously questioned the adequacy of the customary remedies. An explanation may be that the continuous policing of the employer's actions and the ready availability of remedial action reduce the need for deterrent remedies and make the incomplete remedies acceptable.

\section{SUMMARY}

In examining the effectiveness of various remedies in protecting certain employment rights of individuals, I have made no attempt to catalogue all of the available remedies for protecting such rights. Job security is protected by a scatter-shot of other state and federal remedies which protect "whistleblowers," prohibit discrimination based on race, sex, creed, nationality, age, disability, political beliefs, and sexual preference, regulate plant closings, and statutorily proscribe unjust discharge. ${ }^{411}$ Protection against undercompensation may be available under the Walsh-Healey, ${ }^{442}$ Davis-Bacon, ${ }^{443}$ and Service Contract Acts, ${ }^{444}$ state minimum wage laws and wage payment statutes, and remedies for failure to pay severance pay, medical benefits and pensions provided under ERISA. ${ }^{445}$ Protection of physical integrity may also derive from criminal sanctions or third party tort actions against suppliers of defective equipment or dangerous substances. The purpose of this

\footnotetext{
141. For a survey of state and federal workplace rights, see Rabin, supra note 28,

14241 U.S.C. $\$ \S 35-45$ (1988).

14340 U.S.C. $\$ \S 276 a$ to $276 a-5$ (1988 \& Supp. II 1990)

14441 U.S.C. $\$ \S 351-358$ (1988).

44529 U.S.C. §§ 1001-1461 (1988 \& Supp. II 1990).
} at $174-87$. 
article has not been to measure how well the interests of individual employees are protected, but only to understand more clearly how effective particular remedies are in protecting these substantive employment rights.

One major weakness in protecting many substantive rights has not been extensively discussed, but is antecedent to the effectiveness of the remedies. Employees are often unaware of their substantive rights, and therefore do not seek remedies. They do not recognize that their rights to the minimum wage or required overtime pay have been violated by improper deductions from their pay or incorrect methods of calculating the hours worked. Employees do not recognize violations of the $\mathrm{OSH}$ Act because past experiences condition them to expect dangerous practices, unguarded machines, irritating chemicals and poor ventilation as a part of the job. Employees suffering from hearing loss because of deafening noise on the job, carpal tunnel syndrome because of repetitive motions, or heart attacks because of strain or tension from their work, may be unaware that they may be entitled to workers' compensation.

This weakness is not equally troublesome for all substantive rights. Few victims of overt discrimination are unaware of the remedies under Title VII or the ADEA. They may, however, be unaware that the sexual or racial harassment endemic in their workplace is illegal, or that manipulation of pension rights may constitute age discrimination. Many employees protesting, or wanting to protest, working conditions or abusive supervision in a non-union setting do not know that two or three employees acting together constitute protected concerted activity under the NLRA. ${ }^{446}$ Because employees often do not know their rights, employers may ignore or deny them, and the employees may fail to assert or enforce them.

\section{GENERAL GUIDELINES FOR REMEDIES}

The jumble of procedures and remedies for individual employment rights lacks any coherent pattern. The diversity is not entirely a function of the different substantive rights protected. Remedies for discrimination in employment differ without defensible reason. A discharged union member must persuade the General Counsel of

${ }^{146}$ See 29 U.S.C. $§ 157$ (1988); NLRB v. Washington Aluminum Co., 370 U.S. 9 (1962). 
the NLRB to issue a complaint, ${ }^{447}$ but a discharged woman may sue even though the EEOC concludes that her discrimination claim is groundless. ${ }^{448}$ The difference is not grounded in the rights protected, but is caused by historical sequence. The NLRB procedure which denied the employee control over enforcing her rights had proven itself unsatisfactory and was deliberately rejected when the Civil Rights Act was amended in 1972. Although recognized as unsatisfactory for more than twenty years, the NLRB procedure remains unchanged. ${ }^{449}$

Prior to 1991, all discrimination cases under Title VII of the Civil Rights Act of 1964 were triable before a judge, ${ }^{450}$ but discrimination cases under the ADEA are tried before a jury. ${ }^{451}$ Rule 23 class actions may be brought under Title VII, but not under the ADEA. ${ }^{452}$ These distinctions arose because administration of the ADEA was originally placed in the Department of Labor, not the EEOC, and FLSA procedures were made applicable. ${ }^{453}$ Administrative responsibility was later moved to the EEOC, but the FLSA procedures were perpetuated. ${ }^{454}$ Retaliatory discharge victims may receive, under common law remedies, damages not only for lost earnings, but also for emotional distress and punitive damages as well. ${ }^{455}$ Until 1991, sex discrimination victims received only lost earnings. ${ }^{456}$ Work injury victims can recover only medical costs and two-thirds of lost earnings from their employers. ${ }^{457}$ Finally, victims of OSHA violations cannot even sue. ${ }^{458}$ This is the diver-

${ }^{447}$ See supra notes $104-10$ and accompanying text.

448 See supra notes $122-26$ and accompanying text.

${ }^{449}$ See NLRB v. Sears, Roebuck \& Co., 421 U.S. 132, 139 (1975) (noting that the "practical effect of [the] administrative scheme is that a . . victim of an unfair labor practice can obtain neither adjudication nor remedy... . without first persuading the Office of the General Counsel that his claim is sufficiently meritorious to warrant Board consideration").

${ }^{450}$ See 42 U.S.C. $\$ 2000 \mathrm{e}-5(\mathrm{f})(1988)$.

451 See 29 U.S.C. $\$ 626(c)(2)$ (1988). Under the Civil Rights Act of 1991, any party may demand a jury trial if the complaining party seeks compensatory or punitive damages beyond back pay. See Civil Rights Act of 1991 \$ 102(c), 42 U.S.C.A. $\$ 1981$ (a)(c) (West Supp. 1992). But no compensatory or punitive can be awarded in disparate impact cases under $\$ 105$ so no jury trial is available in such cases. See 42 U.S.C.A. § 2000e-2(k) (West Supp. 1992).

452 See 29 U.S.C. $\$ 626$ (c)(2) (1988).

453 See supra notes $188-96$ and accompanying text.

454 See Marion, supra note 188, at 302-03.

455 See supra notes $35-38$ and accompanying text.

${ }^{456}$ See supra notes 149-52 and accompanying text.

${ }^{157}$ See supra note 387 and accompanying text.

${ }^{458}$ See supra text accompanying notes 279-85, 289-94. 
sity and irrationality of the remedies for only the few employment rights examined here.

Despite the jumble of procedures and remedies, it is possible to project some guidelines which have general applicability if individual employment rights are to be effectively enforced. Special tailoring, of course, is needed to fit the remedies to the particular substantive rights protected, but the commonality of the underlying problems points to some basic principles.

First, and fundamentally, employees who believe that their rights have been violated should be able to initiate and press their claims through all procedural steps, including the final appeal. Employment rights should be conceived of as rights belonging to the individual employee, and no agency or official should be able to foreclose the employee from obtaining a hearing and adjudication of those rights.

The official or agency, for political or other reasons, may have limited concern or commitment to enforcing the rights, or may lack the vision or aggressiveness to elaborate the particular rights claimed by employees. The NLRB procedure allows the General Counsel to refuse to issue a complaint and blocks an employee from obtaining a determination of her right by either the Board or a court. ${ }^{459}$ As a result, for twenty years employees victimized by racial discrimination could not obtain protection from such conduct because the General Counsel would not issue complaints in such cases. ${ }^{460}$ When the issue finally came before the Board, it was held to be an unfair labor practice. ${ }^{461}$ Until recently, workers suffering from carpal tunnel syndrome or put at risk by video display terminals have received little or no protection from OSHA. ${ }^{462}$ Courts of appeal have had to order OSHA to adopt adequate standards warning employees of hazardous substances and other matters, ${ }^{463}$ and puny fines reduced the effectiveness of inadequate inspections. ${ }^{464}$ A major weakness of the OSH Act is that

459 See supra note 107 and accompanying text.

160 See supra notes $108-09$ and accompanying text.

161 See supra note 110 and accompanying text.

462 See H. Vincent McKnight, Jr., Biomechanics of VDT Carpal Tunnel Cases, TRIAL, June 1991, at 50, 52 ("OSHA has not yet devised guidelines for the safe use of VDTs.").

463 See, e.g., National Grain \& Feed Ass'n v. OSHA, 858 F.2d 1019, 1035 (5th Cir. 1988) (noting that substantial evidence did not justify OSHA's refusal to adopt a standard requiring grain elevator operators to initiate clean-up procedures whenever grain dust accumulations reached a certain depth).

${ }^{464}$ See supra notes 307-09 and accompanying text. 
endangered employees must look to the agency for protection and cannot proceed on their own to enforce their statutory rights. ${ }^{465}$ This weakness of public enforcement is aggravated when agencies whose statutory responsibility is to protect employee rights are politicized and staffed with appointees who do not believe in those rights or who are more committed to deregulation than to the purpose of the statute.

More importantly, placing sole responsibility on a public agency to protect employee rights holds those rights hostage to budget restrictions. Effective protection can be eviscerated by reducing the funds available for enforcement, a decision of low political visibility. In the last ten years, employee rights have been effectively denied by the unfocused and disassociated policy of "no new taxes." OSHA's severe underfunding, allocated only enough to inspect each establishment once every seventy-five years, ${ }^{466}$ should be an ample object lesson. The EEOC's unanswered pleas for more funds to enable it to conduct needed investigations and bring enforcement suits ${ }^{467}$ and the lack of Wage-Hour Division resources to proceed against sweatshops ${ }^{468}$ also demonstrate dramatically the dependence of employee rights on budget decisions. Our political institutions are much more willing to declare employee rights than they are to provide the funds needed to protect those rights. So long as that is the case, the employees must be able to assert those rights and have them adjudicated without depending on a public agency for enforcement.

The argument is not that enforcement of employment rights should be completely privatized. There is a proper place and, in some instances, a need for public enforcement. Enforcement of certain rights may have broad social purposes beyond the protection of the individual employee. Title VII and FLSA suggest the possibilities of allowing both public and private enforcement. The agency can require record keeping and reporting, and make investigations which will not only disclose violations, but also will help employee plaintiffs prove violations. The agency can bring enforcement actions to fulfill the public interest and aid the employees in bringing suit, but employees should not be foreclosed from enforcing their individual rights by the agency's failure or

465 See supra notes 279-85, 289-94 and accompanying text.

166 See supra note 299 and accompanying text.

167 See supra note 139 and accompanying text.

168 See supra notes 214-24 and accompanying text. 
refusal to act.

Second, if reliance is placed on private enforcement, it becomes crucial to ensure that litigation costs do not preclude employees from pressing their claims. The employment at will cases demonstrate that if the injured employee must pay the costs of court litigation, only those in the upper income brackets with large claims and substantial likelihood of success will obtain a lawyer to press their claims. ${ }^{469}$ A contingent fee will not compensate the lawyer for her time unless the claim is potentially large and lawyers will normally require at least advance payment of out-of-pocket costs. ${ }^{470}$ Provisions in Title VII and the FLSA for payment of attorneys' fees to winning plaintiffs provide a partial solution, but only in cases with a substantial likelihood of success. ${ }^{471}$ Even in those cases, legal costs are a troublesome impediment and the outof-pocket costs may be too large for the injured plaintiff to advance. Also, a lawyer with limited resources may not be able to forego current income and invest the hours needed, particularly in complicated cases, with the prospect of payment only if successful and at the end of extended litigation.

All of this points toward the third guideline: the need for simplified procedures which reduce litigation costs, particularly legal fees. This is not possible in court procedures, which have become encumbered with elaborated pleadings, discovery, depositions, an arsenal of pre-trial memoranda, post-trial briefs and a plethora of other pre- and post-trial proceedings. Employers may deliberately exploit these court procedures in order to discourage employees with limited resources who need prompt relief. Legal costs and delays can be reduced only by using less formal administrative procedures such as those used in workers' compensation proceedings or before the NLRB. The costs of these less formal procedures constitute only a fraction of the costs of judicial proceedings, primarily because they dispense with many of the pre- and posthearing practices. ${ }^{472}$ Costs are reduced even further in labor arbitration, particularly when lawyers are not involved and tran-

169 See supra notes 65-66 and accompanying text.

470 See supra note 67 and accompanying text.

171 See supra notes $167-84,259-65$ and accompanying text.

472 Legal fees for workers compensation cases amounted to only about $3 \%$ of benefits for workers in Wisconsin, $12 \%$ in Florida, and $6 \%$ in California. BERKOWITZ \& BURTON, supra note $\mathbf{3 7 1}$, at $\mathbf{3 8 1}$. This is far less than the one-third or $40 \%$ contingent fees in unjust discharge cases. See supra text accompanying note 56. 
scripts and briefs are waived. ${ }^{473}$

Informal and simple procedures may provide less refined justice. Some facts may not get discovered or fully explored; some legal arguments may not be as fully developed or understood; and the decisions may not be as carefully considered or articulated. Because the procedure is less formal and elaborate, there is less willingness to place large amounts at risk, so recoveries for emotional distress must be limited and punitive damages excluded. ${ }^{47}$ The employee's remedy, therefore, may be less. A balance, however, must be struck between more perfect outcomes and larger recoveries for a few on the one hand, and affordable costs with more limited damages to many on the other. Where the employment rights of individual workers with limited resources are involved, the balance tips heavily on the side of affordable costs and smaller recoveries. More perfect decision-making ought not to be bought by depriving most employees of any decision at all.

Fourth, employees seeking to assert their employment rights must be guaranteed protection from employer retaliation. The NLRA, Title VII, ADEA, FLSA and OSHA all have anti-retaliation provisions, ${ }^{475}$ but the procedures and remedies for retaliation have the same weaknesses as those for other violations. An employee who is discharged because she blows the whistle on safety or health violations cannot bring suit on her own, but must rely on the Solicitor of Labor, who insists she does not have funds to bring suit in more than a small number of such cases. ${ }^{476} \mathrm{~A}$ wage-hour whistleblower may obtain reinstatement, back pay, liquidated damages and attorneys' fees, ${ }^{477}$ if she can find a lawyer to take the case. An employee who is discharged for objecting to an employer's unfair labor practice can file a charge against the employer, but he will have to depend on the General Counsel to file a complaint. ${ }^{478}$ Some workers' compensation statutes have anti-retaliation provisions, ${ }^{479}$ but some do not, and not all state courts have held that

${ }^{473}$ See supra text accompanying notes $428-32$.

474 See supra notes $438-40$ and accompanying text.

475 NLRA § 8(a)(4), 29 U.S.C. \$ 158(a)(4) (1988); FLSA § $216(\mathrm{a})(3), 29$ U.S.C.

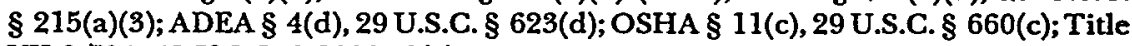
VII $\S 704,42$ U.S.C. $\$ 2000 \mathrm{e}-3(\mathrm{a})$.

476 See supra note 359 and accompanying text.

${ }^{477}$ See 29 U.S.C. $\$ 216$ (1988); see also supra notes $257-69$ and accompanying text.

178 See supra notes $104-10$ and accompanying text.

${ }^{479}$ See, e.g., MASS. GEN. L. ch. 152, §75B(2) (1989); MICH. COMP. LAWS $\S 418.301(11)$ (1985). 
discharges for filing a workers' compensation claim are void as contrary to public policy. ${ }^{480}$ "Whistleblower" statutes, on both the federal and state level, are perforated with loopholes and have proven notoriously ineffective. ${ }^{481}$

Employer retaliation against employees who assert their employment rights should be treated as more than an injury to the employee; it is an offense against the law itself. Punitive damages are particularly appropriate. The employer should be punished both for the purpose of deterrence and for vindication of the law. The employee should recover more than actual damages as a reward for putting himself at risk and as an encouragement to other fearful employees to assert their legal rights.

Fifth, the remedy must contain a visible and substantial element of deterrence. No procedures can be devised which can or will reach all potential violations. There are too many employees and too many workplaces. Too many employers are indifferent or resistant to recognizing various employee rights, and too many employees are uninformed of their rights or reluctant to assert them. To achieve any deterrence, the employer must lose, rather than gain, when it violates those rights. Many employers will, of course, obey the law out of a sense of social and moral obligation, but without a deterrent factor they will be placed at a competitive disadvantage by those who value profits over good citizenship.

Most present remedies provide little or no deterrence. NLRB cease and desist orders do no more than warn the employer not to repeat the violation. An order of back pay to a discriminatorily discharged employee provides some deterrence, for the employer obtains no production for the wages paid, but this cost may be little to pay for discouraging unionization. Back pay awards for FLSA violations carry no sting without the assessment of additional liquidated damages. Citations for health and safety violations and orders to abate create little incentive to provide a safe and healthful workplace, for the fines assessed often cost less than the gain

${ }^{480}$ See, e.g., Martin v. Tapley, 360 So. $2 d 708$ (Ala. 1978) (holding generally that an employment at will contract may be terminated by either party without cause or justification, even if the discharge is malicious); Segal v. Arrow Indus. Co., 364 So. 2d 89 (Fla. 1978) (refusing to recognize a cause of action for wrongful discharge where an employee was allegedly terminated for filing a workers' compensation claim and employment arrangement was terminable at will).

181 See, e.g., SPECTER \& FINKIN, supra note 10, $\$$ 10.01-.22 (discussing federal statutory anti-retaliation and wrongful dismissal regulation); Dworkin \&c Near, supra note 18, at 260-64 (discussing state statutes); supra note 17. 
realized from violations before the inspection. ${ }^{482}$ Inadequate workmen's compensation awards, with the employee bearing a substantial portion of the loss, result in employers not measuring the full economic cost of the injury against the cost of safety measures to avoid the injury. This reduces the number of situations in which the employer's calculus determines that safety pays. Perhaps the greatest deterrence in all employment cases is the employer's legal costs in defending against claims of violation, but these are imposed whether or not the employer has committed a violation.

Although a deterrence factor is essential to providing employers with an incentive to recognize employment rights, relying too heavily on deterrence can be self-defeating. Burdensome penalties tend to discredit the remedy and reduce the willingness of a court or administrative agency to find a violation of substantive rights. The California experience in employment at will cases warns that large recoveries for emotional distress and punitive damages may lead to shrinking or abolishing substantive rights. ${ }^{483}$ Fines for safety and health violations which are too large will lead employers to contest citations and appeal decisions with such frequency that enforcement procedures will become delayed and clogged. Deterrence is better achieved by increasing the percentage of violators held liable than by increasing the penalty on a few unlucky ones brought to book. How much deterrence is enough but not too much also depends on the substantive rights protected, the willingness of employers to recognize those rights, the seriousness of the violations, and numerous other factors. The problem is too complex to do more than identify it here.

Sixth, the remedy must be economically efficient. In employment at will cases, less than one third of the money paid out by employers sued for wrongful discharge ends up with the wronged employee. ${ }^{484}$ The transaction costs of attorney fees and expenses absorb more than two thirds of employer payments, and this does not count the burden on the taxpayer of providing courts to decide the disputes. Judicial remedies under Title VII, the ADEA, and the FLSA have similar transaction costs resulting from enforcement through court litigation. The disproportionate transaction costs cannot be justified except on the basis of providing a substantial

\footnotetext{
482 See supra notes $307-11$ and accompanying text.

${ }^{483}$ See supra notes $82-83$ and accompanying text.

484 See supra notes $44-76$ and accompanying text.
} 
deterrence factor.

High transactions costs again stress the need for simplified procedures, and emphasize the special value of labor arbitration. The litigation costs for arbitration under collective agreements are only about one-tenth of the litigation costs for judicial proceedings, and the parties rather than the taxpayer bear the cost of the tribunal.

Finally, judicial and administrative procedures ought not supplant grievance and arbitration proceedings in protecting contract rights under collective agreements. Grievance arbitration has proven itself acceptable to both unions and employers, and except in rare cases, is far preferable to other procedures available to individual employees. The contract procedures should be given first opportunity to determine and protect individual employment rights. Although these procedures can finally determine only contract rights, they may make unnecessary or discourage pursuit by the employee of common law or statutory rights.

Unions, as representatives of the employees may, and as Professor Rabin has persuasively argued, ${ }^{485}$ should aid employees in enforcing these common law and statutory rights in the administrative and judicial forums. A majority union may appropriately bargain for the grievance and arbitration procedures to be available for adjudicating those rights and encourage employees to use those procedures rather than resort to litigation. The union ought not, however, be able to preclude individual employees, without their consent, from pursuing their common law and statutory rights in the legally designated administrative and judicial forums.

These guidelines cannot, of course, all be fully achieved simultaneously. Individual employees cannot control enforcement of their rights and not bear some of the enforcement costs. Simplified and inexpensive procedures, necessary to reduce the employee's enforcement cost, reduce the deterrent effect provided by the employer's legal costs. Procedures which are economically efficient will likely leave a wronged employee less than fully compensated and employers less than fully deterred. In balancing these competing concerns, the most important consideration is devising a combination which will maximize the number of wronged employees who will seek to enforce their rights and increase the number of violations remedied. Although the remedy may be less

485 See Rabin, supra note 28 , at 242-54. 
than fully adequate in individual cases, more employees will obtain a vindication of the rights, with some measure of recovery, and employers will be deterred by the greater likelihood of liability.

\section{Proposals Beyond The Guidelines}

The preceding discussion has pointed out specific defects in the procedures and remedies for protecting a limited number of employment rights. The purpose has not been to make a comprehensive or detailed analysis, but rather to identify those aspects which limit or frustrate effective protection of employment rights. From this examination of procedures and remedies, certain guidelines evolve which suggest, directly or indirectly, some specific changes. No attempt has been made, however, to elaborate the guidelines or to work out all of their implications for each of the employment rights, although some are self evident. Such detailed development is beyond the reach of this Article.

The guidelines, however, point more generally toward the need for certain institutional and structural changes which will make protection of these rights more effective. First, although employment rights are individual rights enforceable by the individual, it is quite evident that those rights cannot be adequately enforced by individual employees acting alone. Even if the guidelines are followed, too many employees will not know their rights or will be reluctant to assert them alone for fear of retaliation. Even if an employee knows and asserts her rights, the voice of a lonely individual is often too weak to command the employer's attention short of a summons and complaint, and legal action will too seldomly motivate an employer to make a serious effort to settle short of an impending trial. In addition, the cost for each separate individual to obtain a determination of his rights by a separate legal process is discouragingly burdensome even with the simplest procedure of arbitration. ${ }^{486}$

The experience with class actions in Title VII suggests the potential value of employees acting as a group to enforce their individual legal rights. ${ }^{487}$ The need is to create devices beyond the class action which will enable employees to act together to protect their individual legal rights. The most obvious device is a union. Where the union is the majority representative, it can

486 See Jennings \& Allen, supra note 431, at 88

487 See supra note 166 and accompanying text. 
reinforce many of the common law and statutory rights by contractual provisions, and enforce those contract rights through the grievance procedure and arbitration. Collective agreement provisions against discrimination can provide more prompt and effective remedies than Title VII; seniority clauses make the ADEA protection against discharge unnecessary; and the "just cause" clause provides more protection than the expensive and long odds of an employment at will suit. ${ }^{488}$

Common law and statutory rights need not be mirrored in the collective agreement, for, as Professor Rabin has demonstrated, ${ }^{489}$ the grievance and arbitration procedure can be enlarged to adjudicate and enforce these rights directly. Although the majority union could not assert its exclusive representation status in enforcing these rights, the individual's consent after the dispute arises to submit the dispute to arbitration would make the award final and binding. ${ }^{490}$ Such an extension of the grievance and arbitration procedure would seem to be a mandatory subject of bargaining which might be demanded by either the union or the employer, and would seem to be to the advantage of both. Unfortunately, this solution has limited potential, for less than $15 \%$ of employees in the private sector are covered by collective agreements and have the grievance procedure and arbitration available to them.

Even where a union does not have a majority, it can help employees enforce their legal rights by informing them of their rights, collecting evidence, acting as spokesperson in discussions with the employer, providing legal assistance, and even striking in protest of a discharge, discrimination or unsafe working conditions. ${ }^{491}$ Unfortunately, few unions provide such assistance where they are not the majority representative. ${ }^{492}$

In the majority of workplaces, the need remains to provide some institutional structure through which employees can act collectively in protecting their legal rights. Provisions of the Occupational Safety and Health Act suggest a starting place. Section 8 provides:

188 See supra notes $416-26$ and accompanying text.

${ }^{189}$ See Rabin, supra note 28, at 248-49.

490 See id. at 257-58.

191 For the potential role of a non-majority union, see Clyde Summers, Unions Without Majority-A Black Hole?, 66 CHI.-KENT L. REV. 531, 534 (1990) (outlining the ways in which a non-majority union can "represent and serve the interests of workers in the workplace").

192 See id. at 533-34. 
"a representative authorized by his employees" shall be allowed to accompany an inspector in his walk around the plant, ${ }^{493}$ "employees or their representative" must have an opportunity to observe monitoring for toxic chemicals, ${ }^{494}$ a "representative of employees" who believes a violation threatens physical harm or imminent danger may request an inspector and trigger a special inspection, ${ }^{495}$ prior to or during an inspection a "representative of employees" may notify the inspector of any violation which is believed to exist, ${ }^{496}$ and the employee representative is entitled to a review if the Secretary refuses to issue a citation. ${ }^{497}$ Under section 10, a "representative of employees" may contest the length of time given an employer to abate a violation, ${ }^{498}$ and under section 11, may obtain judicial review not only of this issue but any decision of the Commission. ${ }^{499}$ Under section 13, a "representative of employees" who are subject to an imminent danger, which could reasonably be expected to cause death before it could be eliminated through enforcement procedures, can sue for a writ of mandamus to compel the Secretary to seek an injunction. ${ }^{500}$

These provisions hang in the air where there is no union to act as representative, for the Secretary of Labor has not adopted any regulations for determining who is to act as "representative of employees" in the absence of a union. ${ }^{501}$ What is obviously needed is a method for employees to select such a representative in workplaces which have no union. Statutory amendments could provide that in each workplace a safety representative or committee should be elected by the employees, at the request of any employee, with authority to act as their representative under the statute. That authority should not be exclusive, so as not to foreclose individuals or groups of employees from acting on their own, but the safety

49329 U.S.C. $\$ 657(\mathrm{e})(1988)$.

${ }^{494} I d . \S 657(\mathrm{c})(3)$.

$495 I d . \S 657(\mathrm{f})(1)$.

${ }^{496} I d . \S 657(\mathrm{f})(2)$.

497 See id. $\$ 657(\mathrm{f})(2)$.

${ }^{498}$ Id. $\S 659$ (c).

${ }^{499}$ See id. $\$ 660(a)$; see also Oil, Chemical \& Atomic Workers Int'l Union v. OSHRC, 671 F.2d 643, 648-49 (D.C. Cir. 1982) (interpreting $\$ 660($ a) as granting " the union ... a right to appeal the decision of the [Commission]").

${ }^{500} 29$ U.S.C. $\$ 662(\mathrm{~d})$.

501 The Occupational Safety and Health Review Commission has defined an "authorized employee representative" as "a labor organization that has a collective bargaining relationship with the cited employer and that represents affected employees." 29 C.F.R. $§ 2200.1$ (g) (1991). 
representative or committee could act on the request of an employee or on its own.

The functions of such statutory safety committees should not be confined to the narrow observer and appeal roles presently given to "representatives of employees." Nor should such committees be relegated to the consultative role common for voluntary safety committees. ${ }^{502}$ Statutory safety committees should be viewed as the workplace implementors of the statutory provisions and policies, representing the interests of employees, individually and as a group, in having a safe and healthy workplace.

Elementary functions would include the right to inspect regularly and in detail all activities and conditions of the workplace as well as the employer's records of accidents and occupational diseases and the right to be informed, in advance, of proposed use of toxic materials and the introduction of new machines or processes which would create new risks to health and safety. When the statutory representative found conditions which he believed needed correction, he should have the obligation and the right to discuss the matter with management. Where management's response was considered inadequate, the safety committee should be able to call for an inspection. The safety committee could thereby provide an on-going process of inspection more effective than any array of government inspectors could provide. The safety committee should have the same right as the employer to appeal to the Commission from the action or inaction of the Secretary and to obtain judicial review of the Commission's order, and it should have the same standing as the employer in all rule-making and enforcement procedures.

For a statutory committee to perform these functions effectively, the members must be trained so they will recognize safety and health risks and statutory violations. This requires substantial and continuous training. ${ }^{503}$

The multiple functions of safety committees and the need for training raise the question of who should bear the costs. Because these committees would serve, in effect, as substitutes for govern-

502 See Rabin, supra note 28, at 191-92 ("Worker representatives also could play a part in voluntary programs of compliance under OSHA and in facilitating binding settlements of OSHA complaints.").

503 For a statement of what is needed for an effective safety committee in a union context, see BUREAU OF LABOR-MANAGEMENT RELATIONS AND COOPERATIVE PROGRAMS, U.S. DEP'T OF LABOR, THE ROLE OF LABOR-MANAGEMENT COMMITTEES IN SAFEGUARDING WORKER SAFETY AND HEALTH 41 (1989). 
ment inspectors, the cost might be considered the cost of enforcement and be borne by the government. But the responsibility of maintaining a safe and healthful workplace rests on the employer and reducing employee injuries and correcting violations prior to inspection citations also serves the employer's interest. The cost might, therefore, appropriately be placed on the employer. Clearly, however, the cost should not be placed on the employees any more than the employees should be required to provide for their own safety equipment. The committee must also be paid for the time needed to do its job. No employee can be expected to lose work time and earnings to aid the employer in protecting the health and safety of other employees. Again, the question is who is to bear the costs, the employer or the government. There is no need to elaborate the arguments here, but an appropriate allocation would be for the government to bear the costs of education and training, and the employer to bear the cost of lost working time.

The suggestion made here to create statutory safety committees elected by the employees, is neither novel nor remarkable. All of the Western European countries and Canada have such committees. ${ }^{504}$ Even Britain, which historically has emphasized voluntarism in legislation, provides by statute for the establishment of safety representatives and committees ${ }^{505}$ where there is a bargaining relationship, defining their powers and function. Provisions for training and paid time to carry out the work are accepted as essential, and in some countries such as France ${ }^{506}$ and Sweden ${ }^{507}$ the safety committees have much broader functions and greater authority than sketched here.

The proposed Comprehensive Occupational Safety and Health Reform Act, introduced in the Senate in 1991 includes provisions requiring establishment of safety and health committees by all employers of eleven or more employees. ${ }^{508}$ Employee representatives on the committee are to be elected by the employees, and the committee is to have wide authority to make inspections, investigate work accidents, illnesses, and complaints, review injury and illness

${ }^{504}$ See Julie E. Korostoff et al., Rethinking the OSHA Approach to Workplace Safety: A Look at Worker Participation in the Enforcement of Safety Regulations in Sweden, France, and Great Britain, 13 CoMP. LAB. L. J. 45 (1991) (comparing and contrasting the roles of safety committees in Sweden, France, and Great Britain).

505 See id. at $85-88$.

${ }^{506}$ See id. at $65-78$.

507 See id. at 52-56.

${ }^{308}$ See S. 1622, 102d Cong., 2d Sess. tit. II (1991). 
records, make recommendations for improvement of health and safety, and accompany compliance officers in the walkaround on paid time. ${ }^{509}$ Education and training of members of the committee is largely to be paid for by the government. ${ }^{510}$ The proposal does not meet all the needs considered above, but it takes a long step in mandatory election of employee safety representatives. ${ }^{511}$

Such employee committees need not be limited to enforcing employee rights to health and safety, but could help enforce other employee rights. They are especially appropriate for implementing OSHA, for unsafe or unhealthy conditions endanger all employees, even if only random individuals suffer actual injury. Similar committees would be equally appropriate for enforcing employee rights under the FLSA where many employees may be subject to the same violation, but employees may not know their rights or be fearful of enforcing them. Workplace committees would be especially useful in advising injured employees as to workmen's compensation claims and helping them file and process their claims. The committees might serve a similar function for unemployment compensation claims.

Although unjustified dismissals are essentially individual, arbitrary action toward one employee may disclose an employer's attitude which threatens others and creates general insecurity. A dismissed employee could look to a committee for advice and aid in considering legal action. Such committees could be equally useful in helping individual employees know and enforce a wide range of their common law and statutory employment rights ranging from the rights of privacy to rights to pensions under ERISA.

What is being suggested is the possibility of creating employee legal rights committees at the workplace which would enable employees to act as a group to enforce their common individual legal rights. These committees would help overcome the advantage that the employer has because of its dominant authority in the workplace, its greater knowledge, larger resources, and its role as a

${ }^{509}$ See id.

510 See id. \$ 27(c), tit. VII.

511 An Oregon statute empowers the Director of Oregon OSHA to require an employer with 10 or more employees to establish a safety committee under certain circumstances. See OR. REV. STAT. \$ 654.176 (1989). Both the Senate proposal and the Oregon statute provide that the committee have an equal number of employer and employee representatives. See id. \$654.182(1); S. 1622, 102d Cong., $2 d$ Sess. $\S 28(b)(2)$ (1991). Neither make clear whether or when the employee representatives could act alone in requesting inspections, contesting citations, or appealing orders. 
repeat player in the enforcement process. Perhaps most importantly, such committees would provide a structure for negotiating with the employer to settle such claims before they got into the hands of lawyers, and to channel the unsettled claims into arbitration. They would, thereby, serve the long run interests of both the employer and its employees, as well as the social interest in quick and inexpensive resolution of disputes without burdening the legal system.

Such committees should not, of course, have an exclusive right to enforce common law and statutory rights. Individual employees should retain full freedom to proceed on their own to seek help from other sources. For example, employees discriminated against based on of race, sex, age, disability, or union membership might sometimes find workplace committees unhelpful, but they would still be able to seek the help of others in the same group or organizations dedicated to protecting their special interests. The workplace committee would simply be available for those needing and seeking help.

Expanding the function of workplace committees to protecting legal rights beyond safety and health raises problems of who should pay the costs of such committees. If one accepts the principle that the costs of winning plaintiffs should be paid by the employer, then a substantial portion of the costs could be properly assessed against the employer. ${ }^{512}$ A portion, however, should be paid by the employees, both to give the employees more sense that the process belongs to them, and to provide an incentive not to overuse the process. The division of the cost might be fixed in various ways, such as each side paying a percentage, requiring the employer to pay a fixed amount with the employees paying the rest, or requiring the employer to match the amount paid by the employees. Employees might each be assessed a certain amount per month or year, voluntarily subscribe to participate and pay a share, or be assessed for claims processed. There is no time nor need to work out here the advantages and disadvantages of the various means of financing. It is enough to say that the financing problem, though difficult, is not an insuperable obstacle to creating such legal rights

512 Payments by the employer to such committees would presently be barred by § 302(a) of the Labor Management Relations Act, 29 U.S.C. § 186(a) (1988). Employer payments to a labor organization for workmen's compensation cases, however, are presently allowed. See id. $\$ 186(c)(5)$. This exception could be enlarged to cover other employment rights cases. 
committees. ${ }^{513}$

It must be emphasized that legal rights committees would not be engaged in collective bargaining to create contractual rights, but would be engaged only in enforcing existing common law and statutory rights. They would in no way displace unions or collective bargaining. Rather, they would be established only to aid employees not represented by unions-to help secure the legal rights of the $85 \%$ of the workforce which is not protected by recognized unions.

\section{CONCLUSION}

The present wave of increased judicial and legislative protection of employee rights in the workplace, like the earlier wave of legislative protection of collective action, explicitly rejects the economic theory that all terms and conditions of employment should be regulated solely by individual bargaining in a free market. Regardless of whether such a market is economically efficient or subject to disabling market failures, it has results which have been judged to be socially and politically intolerable. As a political society, we have held fast to the conviction that individual employees need protection from market forces.

For nearly half a century, heavy reliance was placed on collective bargaining in a free collective market to protect employees, but that proved inadequate. Although highly effective in protecting rights under the collective contract, collective bargaining sometimes failed to protect the rights of minorities and did not reach rights outside the scope of the contract. Most important, collective bargaining has presently left the vast majority of private employees subject to individual bargaining and its unacceptable results. The response, not surprisingly, has been legally to declare, either by judicial decision or legislation, certain basic employment rights.

The problem of what rights to declare is matched, if not surpassed, by the problem of how to provide remedies which will make those rights real. The present study, although focusing on a limited number of legally protected rights, makes clear that existing remedies for employment rights are seriously lacking, and in some cases distressingly meaningless. Three points of weakness stand out. First, employees cannot rely on government agencies to enforce their rights. Government agencies are too often hobbled by budget

513 For a discussion of various methods of funding the protection of the legal rights of employees, see Rabin, supra note 28, at 211-13. 
limitations and too vulnerable to political appointees who are unsympathetic to the substantive rights meant to be protected. Second, judicial procedures are too cumbersome and expensive to enforce the rights of ordinary workers. Courts are affordable only to the elite, and even in those cases the lawyers go home with most of the money. Third, individual employees, acting alone, lack the information, resources, and psychological support to readily assert their rights against employers who dominate their work life. These factors lead almost inescapably to the need to create workplace structures through which employees can act collectively in protecting their legal rights, and which can provide a negotiating forum with ultimate resort to an arbitration process similar to that provided by collective agreements.

Legal protection of substantive employment rights enforced through such a collective structure falls far short of providing employees protection equivalent to collective bargaining. Legal protection will not reach many rights which can be protected by collective agreements, but will be limited primarily to the more basic employee rights. Also, the in-plant committees proposed here will not have the economic, organizational or financial resources of unions in asserting and enforcing those rights.

Nor can such committees fulfill the Wagner Act's promise of giving employees a measure of industrial democracy, with some voice in the decisions of the enterprise and the operations of the workplace. Legal rights committees can, at most, assure employees that they will enjoy the benefit of decisions made through the political processes. In order for employees who do not have collective bargaining to have any meaningful voice in daily decisions which shape and control their working lives, in-plant committees must have much broader functions, and responsibilities, greater resources, and more substantial organizational structure. Professor Weiler has persuasively developed the case for such committees, and has begun the process of exploring the problems as to their structures, responsibilities and functions. ${ }^{514}$ Legal rights committees might provide some experience about how employee participation committees might be structured and coordinated with collective bargaining. They will in no way satisfy the greater need for providing employees with a measure of industrial democracy.

514 See PAUl C. WEILER, Governing THE WORKPLACE 283-306 (1990) (arguing for employee participation committees and exploring their structure and functions, relationships to unions, and implementation). 